\title{
ÁREAS VERDES COMO REDESTINAÇÃO DE ÁREAS DEGRADADAS PELA MINERAÇÃO: ESTUDO DE CASOS NOS MUNICÍPIOS DE RIBEIRÃO PRETO, ITU E CAMPINAS, ESTADO DE SÃO PAULO
}

\section{ELTIZA RONDINO}

\author{
Dissertação apresentada à Escola Superior de \\ Agricultura "Luiz de Queiroz", Universidade de São \\ Paulo, para obtenção do título de Mestre em \\ Agronomia, Área de Concentração : Fitotecnia.
}

P I R A C I C A B A

Estado de São Paulo - Brasil

Agosto - 2005 


\section{ÁREAS VERDES COMO REDESTINAÇÃO DE ÁREAS DEGRADADAS PELA MINERAÇÃO: ESTUDO DE CASOS NOS MUNICÍPIOS DE RIBEIRÃO PRETO, ITU E CAMPINAS, ESTADO DE SÃO PAULO}

\section{ELTIZA RONDINO}

Engenheiro Agrônomo

Orientador: Prof. Dr. ANA MARIA LINER PEREIRA LIMA

Dissertação apresentada à Escola Superior de Agricultura "Luiz de Queiroz", Universidade de São

Paulo, para obtenção do título de Mestre em Agronomia, Área de Concentração : Fitotecnia.

P I R A C I C A B A

Estado de São Paulo - Brasil

Agosto - 2005 
Dados Internacionais de Catalogação na Publicação (CIP) DIVISÃO DE BIBLIOTECA E DOCUMENTAÇÃO - ESALQ/USP

Rondino, Eltiza

Áreas verdes como redestinação de áreas degradas pela mineração: estudo de casos nos municípios de Ribeirão Preto, Itu e Campinas, Estado de São Paulo / Eltiza Rondino. - - Piracicaba, 2005.

126 p. : il.

Dissertação (Mestrado) - - Escola Superior de Agricultura Luiz de Queiroz, 2005.

1. Áreas verdes 2. Controle ambiental em mineração 3. Impacto ambiental 4. Mineração 5. Reabilitação de áreas degradadas I. Título

CDD 333.72

"Permitida a cópia total ou parcial deste documento, desde que citada a fonte - O autor" 
Aos Meus Pais

Baptista Rondino

e

Elza de Souza Rondino

À Minha Irmã

Elba Rondino

À Minha Tia

Carolina Rondini

DEDICO. 


\section{AGRADECIMENTOS}

Ao Deus, pela oportunidade oferecida e pelas saúde, força e capacidade para pleno cumprimento da jornada.

Aos meus pais, pelos ensinamentos e oportunidades oferecidos durante a vida.

À minha irmã, pelos conselhos e experiência fornecidos em mais esta etapa.

À minha tia, pelos cuidados e carinhos doados em todos os momentos.

À Mary, pela companhia durante a elaboração do trabalho.

À parente e amiga Raquel Laet da Silva, pela amizade e pelos auxílios prestados na digitação do trabalho.

Aos companheiros de emprego Emerson Panis Kaseker, Marta Lucia Nunes Almodóvar, Janaina Yamamoto dos Santos, Marcelo Barreto, Jean Gustavo dos Santos, Obete Mendonça de Melo, Rafael Suzart e Daniel Dalla Vecchia, pelas opiniões acerca dos temas duvidosos referentes ao trabalho e pela rotina diária compartilhada com tanta descontração e afeto.

Aos Fernando Cruz Mendes e Alexandre Sayeg Freire, proprietários da Minaplan Comércio e Serviços LTDA., pelos horários cedidos para cumprimento dos créditos do curso e viagens para visitas técnicas às áreas.

A todos os amigos que, direta ou indiretamente, envolveram-se com essa etapa da minha vida: Alicio Roberto, Karina Idehara, Paulo Obase, Paulo Moraes, Denise Pinesso, Leonardo Gâmbera, Viviane Sampaio, Ana Sansão, Nora Keite.

Aos amigos de profissão conhecidos nessa etapa, Silvana Bortoletto, Luciana Spinello, Priscila Coltri, Roberta Pierry, Pedro Abel, Ivan Alvarez, Luzia Ferreira, às que muito auxiliaram na fase de conclusão do trabalho, Giuliana Velasco e Helena 
Barone Freire e, em especial a Isabel Fialho, Eliane Gomes Fabri e Denise Custódio pelas amizades compartilhadas.

Aos funcionários da Secretaria de Planejamento e Gestão Ambiental da Prefeitura Municipal de Ribeirão Preto, Reginaldo Pereira, Regina Carneiro, Olga Kotchetkoff-Henriques, ao administrador Lázaro Aguiar e à D. Maria Aparecida do Parque Prefeito Luiz Roberto Jábali; à Ana Regina do Departamento de Parques e Jardins da Prefeitura Municipal de Campinas, à Engenheira Agrônoma Claudia Esmeriz do Departamento do Meio Ambiente; ao coordenador do Parque do Varvito José Antônio e ao Senhor Celso Odorico da Secretaria da Cultura da Prefeitura Municipal de Itu; pelas informações fornecidas e pelo material bibliográfico disponibilizado. Em especial ao Sr. Barbosa, administrador da Praça Dr Ulisses Guimarães de Campinas, pela prestatividade no atendimento e pelo afeto e dedicação ao seu trabalho.

À Professora Ana Maria Liner Pereira Lima pela confiança e conhecimentos oferecidos durante toda a orientação do trabalho.

À Comissão do Curso de Pós Graduação em Fitotecnia, nas pessoas dos Professores Drs. Pedro Jacob Christoffoleti, Durval Dourado Neto e Francisco Mourão Filho, pela oportunidade de realização do curso de Mestrado.

À Secretária do Curso de Pós Graduação em Fitotecnia, Luciane Aparecida Lopes, pelos auxílios constantes prestados com tanta dedicação.

Aos Professores Drs. Keigo Minami, Luis Enrique Sanchez, Ricardo Alfredo Kluge, Ângelo Pedro Jacomino, Paulo Pelegrino, Miranda Magnoli, Eugênio Queiroga, Emmanuel dos Santos, Paulo Kageyama, pelos conhecimentos transmitidos nas disciplinas ministradas durante o curso de Mestrado.

Aos Professores João Alexio, Ricardo Ribeiro Rodrigues e Gerd Spavorek pelos auxílios e acréscimos ao trabalho durante o exame de qualificação.

À Eliana Maria Garcia e Silvia Maria Zinsly pela correção final com rapidez e competência.

Enfim a todos que contribuíram, direta ou indiretamente pela realização desse trabalho e cumprimento de mais esta etapa. 


\section{SUMÁRIO}

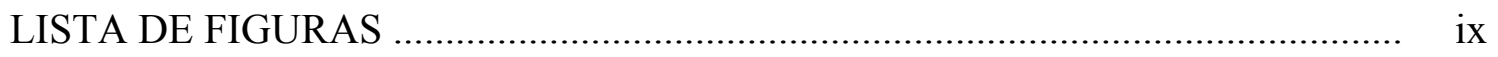

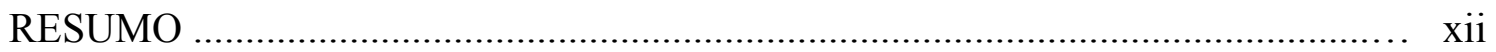

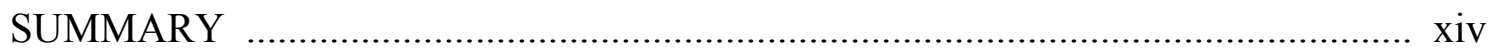

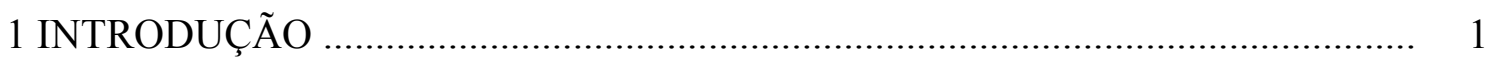

2 REVISÃO DE LITERATURA...................................................................... 4

2.1 Principais conceitos relacionados ao tema............................................................. 4

2.1.1 Degradação ............................................................................................. 4

2.1.2 Impacto Ambiental ........................................................................... 6

2.1.3 Medidas mitigadoras e medidas compensatórias ............................................... 7

2.1.4 Recuperação de áreas degradadas ...................................................................... 7

2.1.5 Recursos minerais e minérios....................................................................... 9

2.1.6 Áreas verdes urbanas e lazer................................................................... 10

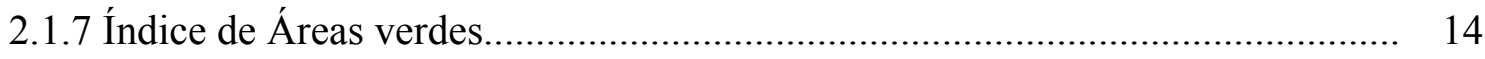

2.2 A Mineração no Brasil e no Estado de São Paulo ................................................ 16

2.3 Impactos Ambientais da Mineração no Estado de São Paulo................................. 22

2.4 Atividades de recuperação de áreas degradadas .................................................. 23

2.5 Instrumentos Legais e institucionais incidentes sobre as áreas sujeitas às atividades de extração e recuperação de substâncias minerais ................................... 25

2.5.1 Das atividades de extração das substâncias minerais.......................................... 25

2.5.2 Da recuperação das áreas degradadas pela mineração ....................................... 28

2.6 Possíveis usos do solo para antigas áreas de mineração ....................................... 33

2.7 Conservação e manutenção de áreas verdes ....................................................... 38

2.8 Áreas degradadas urbanas e Áreas verdes ..................................................... 39 
2.9 Metodologia de análise: estudos de caso ....................................................... 42

3 MATERIAIS E MÉTODOS .................................................................... 44

3.1 Parte teórica ........................................................................................... 44

3.1.1 Parque Luiz Roberto Jábali / Município de Ribeirão Preto / SP ....................... 46

3.1.1.1 Aspectos regionais da área de estudo ....................................................... 46

3.1.1.1.1 História do Município de Ribeirão Preto ..................................................... 46

3.1.1.1.2 Localização e acesso ao Município de Ribeirão Preto ................................... 47

3.1.1.1.3 Aspectos físicos e populacionais do Município ......................................... 48

3.1.1.1.4 Aspectos sociais e econômicos do Município ............................................... 49

3.1.1.1.5 Aspectos vegetacionais do Município ………............................................. 50

3.1.2 Parque do Varvito / Município de Itu / SP ..................................................... 52

3.1.2.1 Aspectos regionais da área de estudo ...................................................... 52

3.1.2.1.1 História do Município de Itu .................................................................... 52

3.1.2.1.2 Localização e acesso ao Município de Itu .................................................... 53

3.1.2.1.3 Aspectos físicos e populacionais do Município ......................................... 54

3.1.2.1.4 Aspectos sociais e econômicos do Município ............................................... 55

3.1.2.1.5 Aspectos vegetacionais do Município .................................................... 55

3.1.3 Praça Ulisses Guimarães / Município de Campinas / SP ................................. 56

3.1.3.1 Aspectos regionais da área de estudo ......................................................... 56

3.1.3.1.1 História do Município de Campinas ......................................................... 56

3.1.3.1.2 Localização e acesso ao Município de Campinas ........................................ 57

3.1.3.1.3. Aspectos físicos e populacionais do Município ………............................... 57

3.1.3.1.4 Aspectos sociais e econômicos do Município ............................................ 59

3.1.3.1.5 Aspectos vegetacionais do Município ....................................................... 60

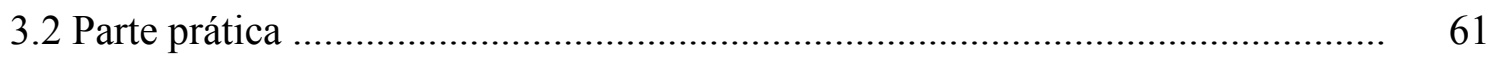

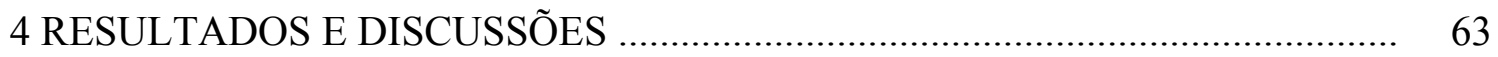

4.1 Parque Luiz Roberto Jábali / Município de Ribeirão Preto / SP .......................... 63

4.1.1 Aspectos locais da área de estudo ............................................................. 63

4.1.1.1 Características gerais do Parque Prefeito Luiz Roberto Jábali ...................... 63

4.1.1.2 Situação da área durante a atividade de extração do minério ......................... 65 
4.1.1.3 Legislações Municipais incidentes sobre a área ....................................... 66

4.1.1.4 Situação atual do Parque Prefeito Luiz Roberto Jábali ................................ 68

4.2 Parque do Varvito / Município de Itu / SP ................................................... 78

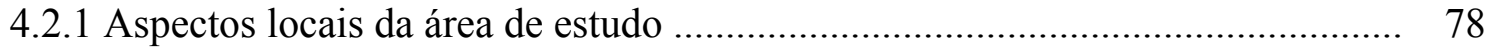

4.2. 1.1 Características gerais do Parque do Varvito .............................................. 78

4.2.1.2 Situação da área durante a atividade de extração do minério ......................... 78

4.2.1.3 Legislações Municipais incidentes sobre a área ........................................ 81

4.2.1.4 Situação atual do Parque do Varvito .......................................................... 81

4.3 Praça Ulisses Guimarães / Município de Campinas / SP .................................. 89

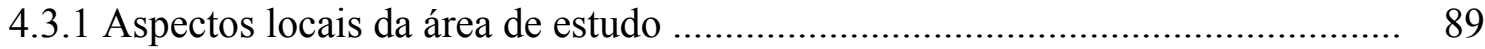

4.3.1.1 Características gerais da Praça Ulisses Guimarães ................................... 89

4.3.1.2 Situação da área durante a atividade de extração do minério ........................ 89

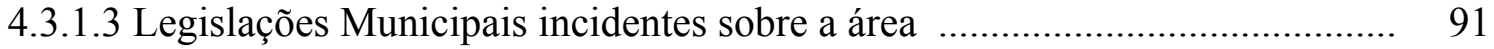

4. 3.1.4 Situação atual da Praça Ulisses Guimarães ................................................ 91

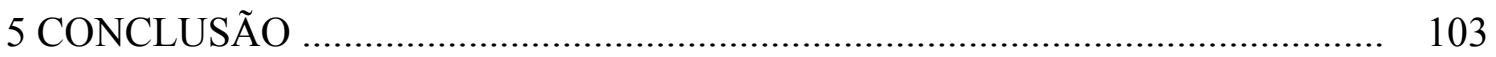

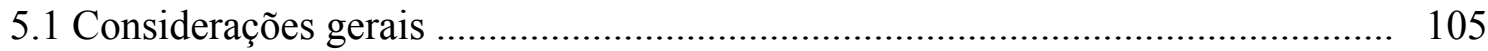

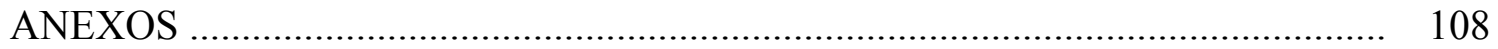

REFERÊNCIAS BIBLIOGRÁFICAS _....................................................... 113 


\section{LISTA DE FIGURAS}

Página

1 Pólos produtores de argila e calcário no Estado de São Paulo.............................. 20

2 Pólos produtores de argila e calcário no Estado de São Paulo .............................. 20

3 Pólos produtores de areia e brita no Estado de São Paulo .................................... 21

4 Pólos produtores de areia e brita no Estado de São Paulo .................................... 21

5 Localização do Parque Luiz Roberto Jábali no Município de Ribeirão Preto........ 64

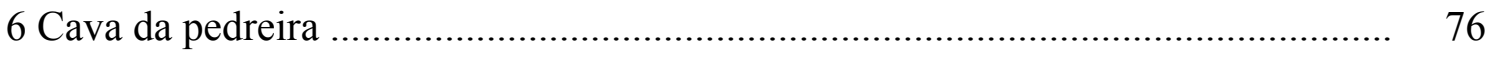

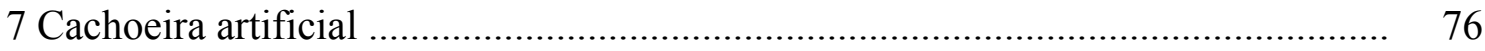

8 Faixa para pedestres e bicicletas .............................................................. 76

9 Maciço de vegetação natural ....................................................................... 76

10 Reservatório de água e bebedouros .............................................................. 76

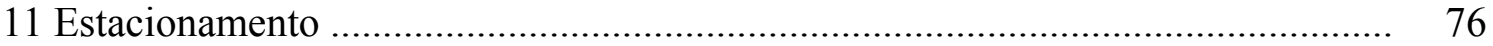

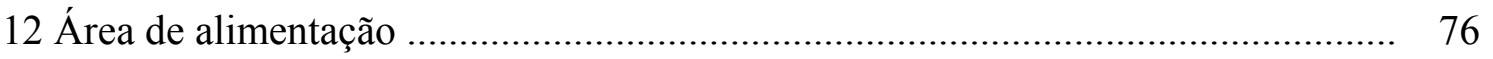

13 Vegetação implantada no parque ............................................................... 76

14 Aviso de "PERIGO” em áreas de risco ............................................................... 77

15 Gramado com problemas de drenagem ...................................................... 77

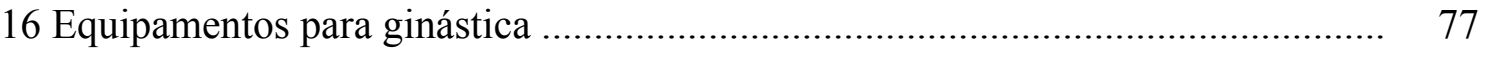

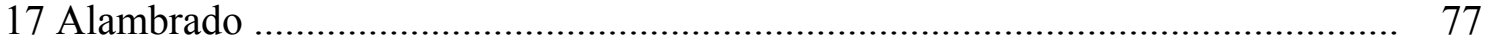

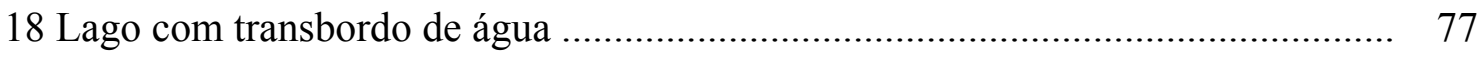

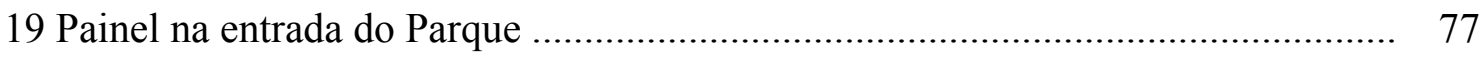

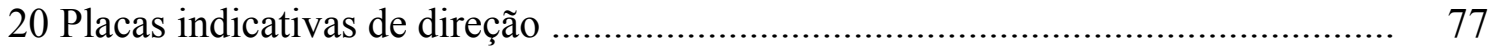

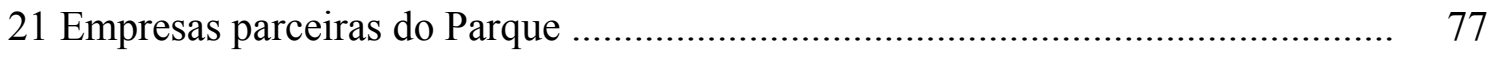

22 Localização do Parque do Varvito no Município de Itu .................................... 79 


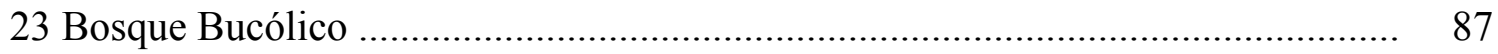

24 Cascata do Antanho (fundo) e Lago dos Fósseis .............................................. 87

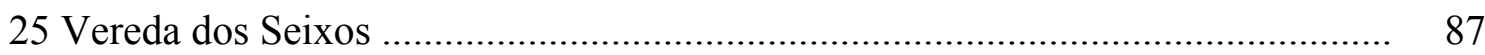

26 Praça Cívica/Galpão Didático ...................................................................... 87

27 Lago Jurássico........................................................................................ 87

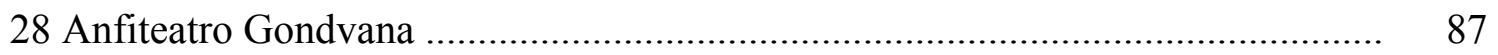

29 Trilha dos Bentônicos ……………………………........................................ 87

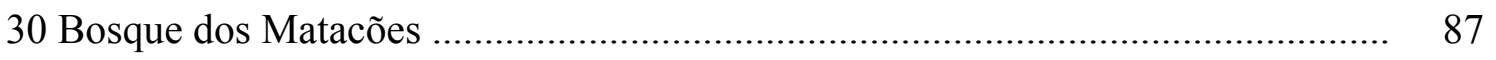

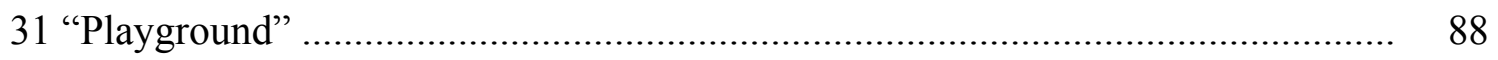

32 Estacionamento ................................................................................. 88

33 Alambrado do Parque do Varvito ………………........................................... 88

34 Administração à esquerda, banheiros ao fundo e orelhão gigante ........................ 88

35 Bancos do Parque do Varvito ………………………................................... 88

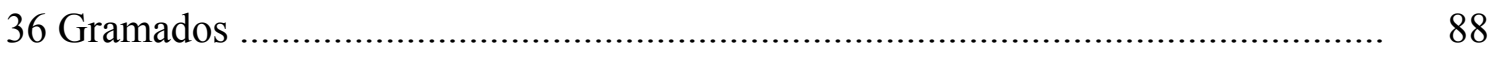

37 Parque Cenozóico ............................................................................... 88

38 Placa da entrada do Parque …………………….................................... 88

39 Localização da Praça Dr. Ulisses Guimarães no Município de Campinas ........... 90

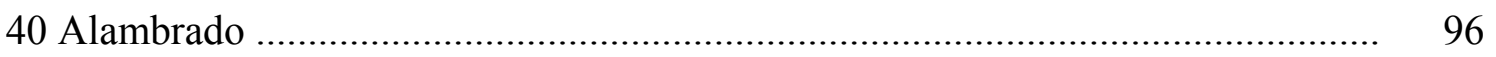

41 Vegetação implantada .............................................................................. 96

42 Vegetação implantada .............................................................................. 96

43 Falta de manutenção do gramado .................................................................... 96

44 Falta de manutenção do memorial ........................................................................ 96

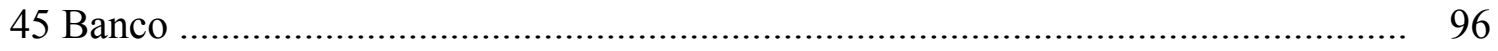

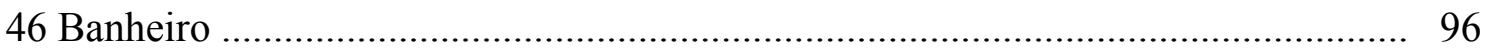

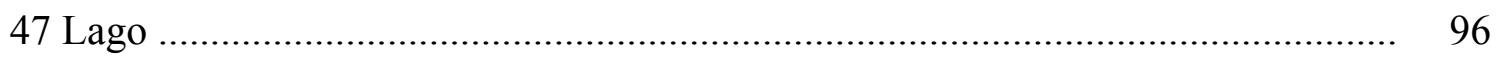

48 Lixeira para materiais recicláveis ………………............................................... 97

49 Memorial Ulisses Guimarães ……………………………………................. 97

50 Placa ao memorial ...................................................................................... 97

51 Palco para apresentações ................................................................................. 97

52 Pista para ciclismo ........................................................................................ 97 


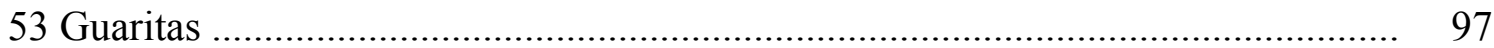

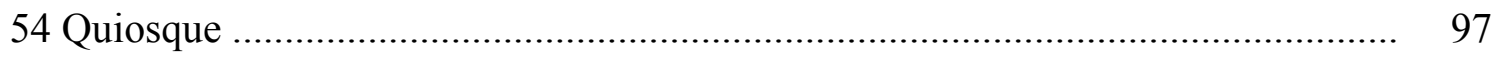

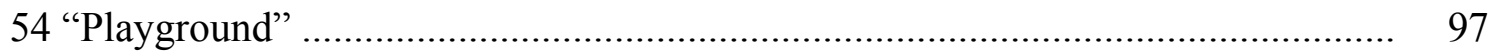




\section{ÁREAS VERDES COMO REDESTINAÇÃO DE ÁREAS DEGRADADAS PELA MINERAÇÃO: ESTUDO DE CASOS NOS MUNICÍPIOS DE RIBEIRÃO PRETO, ITU E CAMPINAS, ESTADO DE SÃO PAULO}

Autora: ELTIZA RONDINO

Orientadora: Prof. Dra. ANA MARIA LINER PEREIRA LIMA

\section{RESUMO}

A finalidade das áreas verdes é oferecer, à população dos grandes centros urbanos, oportunidades de lazer, recreação, bem-estar, aumentando, assim, sua qualidade de vida e seu contato com a natureza. O aumento do índice de áreas verdes nas cidades, expresso pela metragem quadrada de espaços livres de uso público em relação à sua população absoluta, induz a diversas manifestações sociais e culturais e amplia a integração da comunidade, inibindo o uso de tempo e energia com atividades danosas à sociedade, inclusive a violência. A recuperação e reabilitação das áreas degradadas pela mineração tornaram-se obrigatoriedade legal, a partir de 1988, com o advento da atual Constituição Brasileira. A existência de diversos sítios degradados nas áreas urbanas dos municípios, resultantes da extração mineral, constituindo espaços livres abandonados e a necessidade de cumprimento da legislação, incentiva a ocupação de tais locais por áreas verdes. A redestinação destes locais degradados pela mineração, em áreas verdes públicas, é uma das alternativas mais eficientes em aumentar o índice de áreas verdes das grandes cidades e ampliar suas opções de lazer. Com o objetivo de aliar o 
cumprimento da legislação vigente sobre recuperação de áreas degradadas, com as funções primordiais da criação de áreas verdes, foram analisados três casos de áreas verdes públicas paulistas, que outrora foram mineradas para a extração de materiais aproveitados na construção civil e utilizaram o mesmo método de lavra. Os locais escolhidos para estudo foram o Parque Luiz Roberto Jábali, o Parque do Varvito e a Praça Dr. Ulisses Guimarães, localizados, respectivamente, nos Municípios de Ribeirão Preto, Itu e Campinas. O método de pesquisa utilizado foi o de estudo de caso. A parte teórica do trabalho consistiu no levantamento de dados bibliográficos regionais e locais sobre as áreas de estudo. A parte prática consistiu no levantamento de dados em campo sobre a situação atual de cada uma das áreas verdes estudadas, através de visitas técnicas para coleta dos dados primários, por meio da comunicação e da observação direta sistemática. A manutenção do Parque Prefeito Luiz Roberto Jábali foi considerada altamente positiva. O local cumpre as funções primordiais de uma área verde, além de contribuir para o aumento do índice de áreas verdes do Município de Ribeirão Preto. O Parque do Varvito apresenta algumas benfeitorias mal conservadas, porém cumpre suas funções culturais e paisagísticas, elevando, também, o índice de áreas verdes do Município. A Praça Dr. Ulisses Guimarães encontra-se abandonada pela Prefeitura Municipal de Campinas e, embora eleve o índice de áreas verdes do Município, não atinge os objetivos básicos de uma área verde municipal. Os sítios urbanos degradados pela mineração são potenciais opções de aumento do índice de áreas verdes num determinado Município. Contudo, somente atingirão tais funções, contemplando bemestar, lazer e recreação à população, quando a conservação e a manutenção forem bem conduzidas pelas políticas governamentais de gestão e fiscalizadas pela comunidade. 


\section{GREEN AREAS RECOVERED FROM DEGRADED MINING SITES: CASE STUDIES IN THE MUNICIPALITIES OF RIBEIRÃO PRETO, ITU AND CAMPINAS, STATE OF SÃO PAULO}

Author: ELTIZA RONDINO

Adviser: Prof. Dra. ANA MARIA LINER PEREIRA LIMA

\section{SUMMARY}

The purpose of a green area or public park is to offer the population of large urban centers an area where they can enjoy leisure and recreation, thus increasing their quality of life and contact with nature. The ratio of green in a city, expressed by the area of public space such as parks divided by the population, is linked to numerous social and cultural manifestations and increases community integration, inhibiting the use of time and energy with activities that can be considered harmful to society, including violence. The recovery and rehabilitation of areas degraded by mining are required by law since 1988, after the promulgation of the Brazilian Constitution. The fact that there is a great number of sites in cities' urban areas that have been degraded as a result of mineral extraction and later become public areas covered by vegetation, has led to making public parks a common alternative when recovering an area, especially because of legal requirements. It is one of the most efficient alternatives when it comes to increasing green areas and leisure spots. It was with the objective of joining compliance with the current legislation on rehabilitation of degraded areas with the basic functions of increasing the number of green areas, that three such areas were analyzed; all in the State of São Paulo and all formerly mined for construction material using the 
same extraction procedures. The areas chosen for the study were the Parque Luiz Roberto Jábali, the Parque do Varvito and the Praça Dr. Ulisses Guimarães, located respectively in the Municipalities of Ribeirão Preto, Itu and Campinas. The survey method used was the case study. The theoretical aspect of the study consisted in finding local and regional bibliographical data on the areas. The practical aspect consisted in gathering field data on the current situation of each one studied, by means of conducting technical visits for primary data collection through direct and systematic observation. Maintenance of the Parque Prefeito Luiz Roberto Jábali was considered very positive. The location achieves the primary purposes of a green area, and also makes a contribution to the ratio of green in the Municipality of Ribeirão Preto. The Parque do Varvito presents a few positive aspects as far as what it offers, but maintenance has been fairly poor. It does, nonetheless, carry out its cultural and landscaping functions, also helping the ratio of green. The Praça Dr. Ulisses Guimarães has been abandoned by the Municipal Authorities and contributes only to the green area in Campinas, not achieving the primary goals of a Municipal green area. The recovery of a degraded mining is an option for increasing the area of green in a given Municipality; it will, however, only fulfill the purposes of urban green areas, i.e. to increase overall well-being of the population by offering leisure and recreation, when it is duly preserved and maintained with help from government policies and the community. 


\section{INTRODUÇÃO}

A aceleração histórica do crescimento urbano no Estado de São Paulo e a geologia dos terrenos paulistas, levaram à produção preferencial por depósitos de matérias-primas, visando o uso na construção civil (areia, brita e rochas ornamentais, argilas para cerâmica vermelha e rochas carbonáticas para fabricação de cimento e cal); tal exploração representa mais de $90 \%$ do valor da produção mineral do Estado.

A recuperação e reabilitação das áreas mineradas tornaram-se obrigatoriedade legal somente com o advento da Constituição Brasileira de 05 de outubro de 1988. O artigo 225 da Constituição, em seu parágrafo $2^{\circ}$, estabelece que: "Aquele que explorar recursos minerais fica obrigado a recuperar o meio ambiente degradado, de acordo com solução técnica exigida pelo órgão público competente, na forma da lei”. Para regularização da Carta Magna, o Decreto n ${ }^{\circ} 97.632$ de 10 de abril de 1989 estabelece que os empreendimentos minerários já instalados devem apresentar os Planos de Recuperação de Áreas Degradadas (PRAD) para continuidade de suas atividades. Estes projetos devem apresentar a definição do uso futuro do solo para a área explorada.

Dentre esses usos, a redestinação da área como parques e áreas verdes, na zona urbana dos Municípios, auxilia no aumento da qualidade de vida da população, perdida nos grandes centros, ampliando o índice de área verde por habitante nos Municípios.

Somente nos últimos vinte anos do século XX observa-se um interesse político crescente pela implantação e formação de parques públicos. Essa tendência é influenciada pela crescente urbanização do país, que levou a grande maioria da população a residir em cidades. Iniciou-se, no final desse século, um processo crescente de implantação desse tipo de logradouro nos médios e grandes aglomerados urbanos, de 
responsabilidade tanto dos Municípios, como dos governos estaduais (Macedo \& Sarata, 2003).

A criação de novos parques e áreas verdes melhora e pode devolver ao ambiente as condições responsáveis pelo conforto ambiental, como radiação, temperatura, velocidade do vento, precipitação e umidade do ar, entre outros. A redestinação das áreas degradadas para fins de parques, em áreas metropolitanas, transforma a paisagem local e, quando bem mantidas e tratadas, oferecem à população bem-estar e aumento de qualidade de vida.

É recente o estudo sobre recuperação de áreas degradadas pela mineração e sobre a redestinação dessas áreas para parques e áreas verdes públicas.

No Município de São Paulo, Estado de São Paulo, o Parque Cidade de Toronto e o Parque Ecológico Tietê, localizados na zona norte da cidade, o Parque Ibirapuera, na região central e o Parque Villa Lobos, na zona oeste são antigas extrações de areia. O Parque São Domingos, na região Noroeste, é uma área minerada de basalto para brita reabilitada como área verde pública.

No Estado de São Paulo, algumas áreas verdes são conhecidas como locais outrora minerados: Parque Francisco Rizzo, extração de areia, Município de Embu; Parque Prefeito Luiz Roberto Jábali e Parque Dr. Luiz Carlos Raya, extração de basalto para brita, Município de Ribeirão Preto; Praça Dr. Ulisses Guimarães, extração de diabásio para brita, Município de Campinas; Parque do Varvito, extração de varvito, Município de Itu; Parque das Lavras e Parque da Rocha Mountoneé, extração de varvito, Município de Salto.

No Município de Curitiba, o Parque da Pedreira, onde se encontra a Ópera de Arame, a sede da Universidade Livre do Meio Ambiente, no Bosque Zaninelli, o Parque Tanguá e o Parque Ecológico Costa foram construídos em antigas áreas de exploração de matérias primas para produção de brita.

O presente trabalho tem como objetivos principais analisar três áreas que outrora foram minerações, localizadas em zona urbana de Municípios paulistas, quanto às suas características gerais, ao cumprimento da legislação vigente sobre recuperação de áreas degradadas pela mineração e à sua manutenção e conservação. 
As áreas escolhidas para estudo foram o Parque Prefeito Luiz Roberto Jábali / Município de Ribeirão Preto / SP, o Parque do Varvito / Município de Itu / SP e a Praça Dr. Ulisses Guimarães / Município de Campinas / SP. Tais áreas concentram-se em atuais áreas verdes públicas, que foram mineradas para a extração de materiais aproveitados na construção civil e utilizaram o mesmo método de lavra - rocha para brita (em Ribeirão Preto e Campinas) e varvito (em Itu) - lavras em encosta, conduzidas a seco, desenvolvidas em maciços rochosos, em minas a céu aberto, por escavação mecânica com formação de bancadas, utilizando, quando necessário, o desmonte da rocha por explosivos. 


\section{REVISÃO DE LITERATURA}

\subsection{Principais conceitos relacionados ao tema}

O levantamento dos diversos aspectos envolvidos na recuperação de áreas degradadas exige uma reflexão conceitual sobre os principais termos envolvidos no assunto.

\subsubsection{Degradação}

O conceito de degradação tem sido geralmente associado aos efeitos ambientais considerados negativos ou adversos e que decorrem, principalmente, de atividades ou intervenções humanas. Raramente o termo se aplica às alterações decorrentes de fenômenos ou processos naturais. $\mathrm{O}$ conceito varia segundo a atividade em que esses efeitos são gerados, bem como em função do campo do conhecimento humano em que são identificados e avaliados (Bitar, 1997).

Cairns $\mathrm{Jr}^{1}$ citado por Bitar (1997) utiliza o termo perturbação ou distúrbio como alteração resultante de atividades humanas e que não pode ser corrigida rapidamente, citando três situações influenciadas pelo caráter temporal: os distúrbios súbitos e inesperados, como os decorrentes de acidentes ou falhas de origem tecnológica em processos industriais; os distúrbios que ocorrem durante período de tempo significativo, mesmo que tenham sido detectados apenas recentemente, como os derivados de

\footnotetext{
${ }^{1}$ CAIRNS JR., J. Restoration, reclamation and regeneration of degraded or destroyed ecosystems. In:
} SOULÉ, M.E. (Org) Conservation biology. Sunderland: Sinauer, 1986. p.465-484. 
descargas de efluentes industriais; e os distúrbios planejados, como os da mineração em superfície.

Já Toy \& Hadley ${ }^{2}$ citado por Bitar (1997), correlacionam conceitos de perturbação ou distúrbio com os efeitos geomórficos produzidos na paisagem por diferentes atividades humanas como mineração em superfície, urbanização, pastagem, agricultura, usos recreativos e construção civil. Reconhecem que muitos desses distúrbios têm importância menor ou são transitórios e que a paisagem pré-existente pode ser recuperada para uma forma aceitável de produtividade e de acordo com um plano de uso prévio.

Willians et al (1992) definem que "a degradação de uma área ocorre quando a vegetação nativa e a fauna forem destruídas, removidas ou expulsas; a camada fértil do solo for perdida, removida ou enterrada; e a qualidade e regime de vazão do sistema hídrico for alterado". A degradação ambiental "ocorre quando há perda de adaptação às características físicas, químicas e biológicas do solo e é inviabilizado seu desenvolvimento socioeconômico".

Maschio et al (1992) utilizam termos em seqüência gradativa e crescente para conceituar degradação: a perturbação ocorre quando o desgaste é parcial e reversível; a descaracterização acontece quando o desgaste é total e reversível; na depauperação, o desgaste é parcial e irreversível e na degradação o desgaste é total e irreversível, ocorrendo a destruição do ecossistema.

Dias \& Griffith (1998) relacionam as áreas degradadas e a degradação do solo aos seguintes fatores: desmatamento ou remoção da vegetação natural para fins de agricultura, florestas comerciais, construção de estradas, urbanização; superpastejo da vegetação; atividades e práticas agrícolas; exploração intensa da vegetação para fins domésticos e exposição do solo a agentes erosivos; atividades industriais ou bioindustriais.

\footnotetext{
2 TOY, T.J.; HADLEY, R.F. Geomorphology and reclamation of disturbed lands. London: Academic Press, 1987. 480p.
} 
$\mathrm{Na}$ área ambiental urbana, o conceito de degradação está associado à perda da função urbana e das formas de uso do solo existentes nas áreas consideradas, em relação às condições preexistentes e às previstas em diretrizes do planejamento (Bitar, 1997).

Todas essas definições deixam claro que o conceito de degradação está intimamente ligado a alterações provocadas no meio ambiente por ações humanas consideradas adversas, seja no ar, nas águas e/ou no solo, que tendem a incluir efeitos negativos ao uso do solo em sua função potencial.

\subsubsection{Impacto Ambiental}

Impacto Ambiental é "qualquer alteração das propriedades físicas, químicas e biológicas do meio ambiente, causadas por qualquer forma de matéria ou energia resultante das atividades humanas[...]" (Resolução do Conselho Nacional do Meio Ambiente - CONAMA- $n^{\circ} 01$ de 23/01/1986), que afetam a saúde, a segurança, o bemestar da população, as atividades sociais e econômicas, a biota, as condições estéticas e sanitárias do meio ambiente e a qualidade dos recursos ambientais.

O Código do Meio Ambiente do Município de Ribeirão Preto (2004), em seu artigo 141, define impacto ambiental como o efeito que determinadas ações antrópicas e/ou naturais produzem nos elementos de uma paisagem, acarretando conseqüências negativas ou positivas na sua qualidade.

A avaliação dos impactos ambientais é um instrumento de política ambiental, formado por um conjunto de procedimentos, capazes de assegurar que se faça, desde o início do processo, um exame sistemático dos impactos ambientais de uma ação proposta e de suas alternativas; os resultados devem ser apresentados e considerados de forma adequada ao público e aos responsáveis pela tomada de decisão. Além disso, os procedimentos devem garantir a adoção das medidas de proteção ao meio ambiente determinadas, no caso de decisão sobre implantação do projeto (Moreira, 1992). Essa não deve ser considerada apenas como uma técnica, mas como uma dimensão política de gerenciamento, educação da sociedade e coordenação de ações impactantes. 
A avaliação dos impactos ambientais pode ocorrer em dois momentos: antes da ação potencialmente impactante - avaliação "ex-ante", e depois dela - "ex-post". O monitoramento ambiental pode ser parte integrante dos processos de avaliação (Spadotto, 2002).

A avaliação de impacto ambiental, como instrumento de decisão na aprovação de projetos, atividades e mesmo políticas, leis, planos e programas, encontra-se hoje disseminada amplamente em todo o mundo, seja inserida no sistema de proteção do meio ambiente de muitos países (mais de uma centena), na forma de leis ou procedimentos administrativos, seja pela atuação de organismos internacionais, dos quais depende a maioria dos grandes projetos de infra-estrutura dos países em desenvolvimento (Dias, 2001).

\subsubsection{Medidas mitigadoras e medidas compensatórias}

Os impactos ambientais negativos inerentes à implantação de uma atividade minerária, quando inevitáveis, levam ao estudo de medidas que visam atenuá-los ou eliminá-los durante o funcionamento da mina. São as chamadas medidas mitigadoras. Quando os impactos não podem ser evitados e não são passíveis de atenuação devem ser propostas as medidas compensatórias (Dias, 2001). Equipamentos mitigadores de impactos ambientais implementados nas indústrias, canaletas de drenagem, bacias de decantação e cortinas vegetais nas minerações, práticas conservacionistas e uso apropriado de máquinas agrícolas nas atividades agropecuárias, são alguns exemplos de medidas mitigadoras à degradação ambiental.

\subsubsection{Recuperação de áreas degradadas}

A recuperação de áreas degradadas tem sido discutida multidisciplinariamente, já que envolve ações que visam o retorno do sítio degradado a condições de reutilização do ambiente outrora danificado. Outras definições foram relacionadas ao termo "recuperação" e analisadas em diversos estudos sobre o tema. 
A recuperação de áreas degradadas significa que o "sítio degradado será retornado a uma forma e utilização de acordo com um plano preestabelecido para o uso do solo. Implica que uma condição estável será obtida em conformidade com os valores ambientais, estéticos e sociais da circunvizinhança. Significa também que o sítio degradado terá condições mínimas de estabelecer um novo equilíbrio dinâmico, desenvolvendo um novo solo e uma nova paisagem" (Willians et al, 1990).

A restauração (Willians et al, 1990) é o retorno ao estado original antes da degradação e a reabilitação é o retorno do sítio degradado a um estado biológico apropriado, que significará o uso produtivo da área em longo prazo, tal como a implantação de uma atividade que renderá lucros ou atividades que visam a recreação ou valorização estético-ecológica do local.

A reabilitação pode ser dividida em reabilitação condicional e reabilitação autosustentável. A reabilitação condicional refere-se à reabilitação provocada pelo homem, que reabilita a área para manejos de reflorestamento e pastagens, por exemplo. A reabilitação auto-sustentável é o manejo de uma área até atingir um ponto em que a ação do homem não seja mais necessária. Os ciclos de nutrientes são fechados e os componentes da biota estão razoavelmente em equilíbrio; por exemplo, uma floresta com vegetação nativa, dedicada à manutenção da vida selvagem (Willians et al, 1990).

Segundo Bitar (1997), na literatura técnica internacional, o termo restauração aparece relacionado a remediação de áreas contaminadas por resíduos ou rejeitos.

Almeida \& Bruna ${ }^{3}$ citado por Bitar (1997) relatam que, no campo do urbanismo, os conceitos aplicados à questão ambiental das cidades contemplam uma vasta diversidade de termos como recuperação, renovação, reabilitação, reestruturação, remodelamento e revitalização.

O termo remediação é utilizado para áreas contaminadas por resíduos e rejeitos, que necessitam de implantação de medidas de tratamento dos solos e/ou das águas superficiais e subterrâneas afetadas pela atividade exercida no local (Bitar, 1997).

\footnotetext{
${ }^{3}$ ALMEIDA, C.M.; BRUNA, G.C. Conceitos de preservação, recuperação, renovação, reabilitação e revitalização ambiental urbana: principais exemplos e técnicas utilizadas. São Paulo: FAU/FSP-USP, 1996. (Roteiro geral de disciplina sobre gestão de áreas especiais).
} 
Rodrigues \& Gandolfi (2001) definem os seguintes termos relacionados à recuperação de áreas degradadas: "restauração 'sensu strictu', que significa um retorno do ecossistema degradado às condições ambientais originais tanto florística quanto faunística; "restauração 'sensu lato' que significa um retorno do ecossistema a uma condição próxima à original: ocorre quando a perturbação na área não foi muito intensa; a "reabilitação" significa o retorno a um "estado estável alternativo", com forte intervenção antrópica; e "redefinição "ou" redestinação" constitui na conversão de um ecossistema degradado a um ecossistema com destino ou uso distinto do original, como por exemplo: cavas de mineração em reservatórios hídricos ou áreas degradadas em áreas agrícolas. Willians et al (1990) caracteriza o termo "recuperação" numa situação intermediária entre "restauração sensu lato" e "reabilitação".

\subsubsection{Recursos minerais e minérios}

Gomes $^{4}$ citado por Tanno \& Sintoni (2003) define recurso mineral como uma concentração natural de materiais sólidos, líquidos ou gasosos, à superfície ou no interior da crosta terrestre, de tal forma que a extração econômica de uma substância útil seja potencialmente viável. Assim, o termo pode ser aplicado a todos os minerais ou substâncias minerais com valor para o homem, no presente ou no futuro.

$\mathrm{O}$ termo minério, que originalmente se empregava apenas para indicar a "substância mineral da qual se podia extrair economicamente um ou mais metais", evoluiu conceitualmente para referir-se a "todas as substâncias minerais que saem de uma mina e que tenham valor econômico" (Tanno \& Sintoni, 2003).

Dentre as substâncias minerais mais comuns produzidas e relacionadas com o consumo doméstico das cidades brasileiras estão os materiais para construção civil, argila para cerâmica vermelha, rochas calcárias, material de empréstimo e água mineral e potável de mesa. Excetuando os combustíveis fósseis, os materiais de construção são

4 GOMES, C.S.F. Minerais industriais - Matérias-primas cerâmicas. Aveiro: Instituto Nacional de Investigação Cientifica. 1990. 247p. 
as substâncias minerais mais utilizadas (em volume e valor) em todo o mundo. (Tanno \& Sintoni, 2003).

Deve ser ressaltado que, embora utilize os mesmos equipamentos e o "modus operandi" de uma mineração, a extração de areia e rocha para britagem nem sempre é reconhecida como uma mineração típica, tais como a extração de minério de ferro e outros metais ou do carvão mineral, fosfato ou diamante. Muitas vezes, isso se reflete em legislação mineral restritiva, de escopo menos abrangente, em que a decisão para sua instalação fica em níveis administrativos mais baixos. Essa forma de ser encarada traz não raras vezes sérios problemas para o setor, tais como necessidade de licenciamentos mais freqüentes, direitos de anterioridade não reconhecidos, alvo de ações de desapropriação, dificuldades na obtenção de financiamento. As estatísticas sobre produção refletem bem o tratamento discriminado que o setor recebe. Muitos produtores ainda produzem de maneira informal, isto é, não totalmente legalizados perante a legislação mineral. Se na legislação mineral as extrações de areia e pedra não são consideradas minerações, quando se trata da questão ambiental, não raramente são consideradas como altamente danosas, comparável às minerações ditas típicas. As exigências e restrições passam a ser as mesmas destas, embora suas conseqüências para o meio ambiente sejam muito menores (Valverde, 2001).

\subsection{6 Áreas verdes urbanas e lazer}

Os Municípios brasileiros são divididos, legalmente, em áreas urbanas, áreas de expansão urbana e áreas rurais. Dentro das áreas urbanas estão os espaços com edificações, os espaços livres de edificações (praças, parques, quintais) e os espaços de integração urbana (rede rodo-ferroviária). Os espaços livres de edificações ou espaços livres podem ser de caráter público, privado ou privados de uso coletivo e são as áreas não edificadas de uma cidade. Quando os espaços livres são destinados à preservação ou implantação de vegetação ou do lazer público, passam a chamar-se áreas verdes, que podem ser dotadas de vegetação de ocorrência natural ou implantada. As áreas verdes pequenas são os jardins, praças e parques lineares que têm incorporado a função de áreas 
para exercícios físicos e caminhadas. As áreas verdes grandes são os Parques Municipais ou similares, que cumprem funções primordiais em relação à circulação atmosférica, preservação de uma parte da paisagem natural, educação ambiental, convívio com a natureza e local de recreação e lazer (Lira Filho et al, 2001).

Silva (1981) define áreas verdes como os locais com vegetação contínua, livre de edificações, mesmo que recortadas por caminhos, vielas ou com a presença de brinquedos infantis e outros divertimentos leves, desde que se destinem ao uso público.

Do ponto de vista conceitual,uma área verde é sempre um espaço livre, incluindo, portanto, áreas com vegetação, fazendo parte de equipamentos urbanos, parques, jardins, cemitérios existentes, áreas de pequenos jardins, alamedas, bosques, praças de esporte, "playgrounds", "playlots", balneários, "camping” e margens de rios e lagos (Cavalheiro \& Del Picchia, 1992). Para estes autores, o termo espaço livre deveria ser preferido ao de área verde, por ser mais abrangente, incluindo, inclusive, águas superficiais.

O termo espaço aberto é visto como um anglicismo, pois a palavra inglesa é "open space"' e não "free space”, tendo sido, erroneamente, traduzido, ao pé da letra. Para existir espaço aberto em urbanismo, o termo utilizado deve ser área aberta. Os espaços livres desempenham papel ecológico, de integrador de espaços diferentes, baseando-se, tanto em enfoque estético, como ecológico e de oferta de áreas para o desempenho de lazer ao ar livre (Cavalheiro \& Del Picchia, 1992).

Lima et al (1994) relacionam área verde àquela com o predomínio de vegetação arbórea, englobando as praças, os jardins públicos, os parques urbanos e os canteiros centrais de avenidas, as rotatórias e os trevos de vias públicas, excluindo, na definição, o leito das vias públicas. As praças têm como principal função o lazer, podendo ter ou não vegetação e ser impermeabilizada.

Demattê (1997) aplica o termo "áreas verdes" a diversos tipos de espaços urbanos, públicos ou particulares, que têm em comum: serem abertos (ao ar livre), acessíveis e relacionados com saúde e recreação.

As áreas verdes e os espaços livres desempenham, no meio urbano, valores paisagísticos (ao enfatizar as características físicas do sítio e atuar como limites de áreas 
urbanizadas, formando compartimentos de paisagem), valores recreativos (quando supre a carência de áreas de lazer na cidade) e valores ambientais (Lira Filho et al, 2001).

Há diversos espaços urbanos ligados às áreas verdes urbanas: jardins, praças, parques, unidades de conservação, bosques, campus universitários, cemitérios, estádios de futebol, clubes sociais, hortos, viveiros, entre os quais "parques" e "praças" merecem ser destacados e definidos.

Dentro da malha urbana, são os parques de bairro e distritais/setoriais, que cumprem as funções de lazer à população. Os parques de bairro devem possuir 6,0 $\mathrm{m}^{2} /$ habitante e uma área mínima de 10 ha e os parques distritais ou setoriais devem possuir 6,0 a 7,0 m²/habitante e uma área mínima de 100 ha (Cavalheiro \& Del Picchia, 1992).

Os parques (Escada, 1992) dividem-se em parques de bairro (de menores dimensões, devendo conter uma gama maior de equipamentos de lazer, podendo desempenhar função paisagística e ambiental) e parques distritais (espaços livres de grandes dimensões; são áreas de bosques que contém elementos naturais de grande significado, tais como montanhas, cachoeiras, florestas; devem ser concebidos e equipados para permitir acampamentos, possuir trilhas para passeios a pé e a cavalo, locais de banho, natação, esporte e outros).

De acordo com Kliass (1993), os parques urbanos são espaços públicos com dimensões significativas e predomínio de elementos naturais, principalmente cobertura vegetal, destinados à recreação.

Segundo Lima et al (1994), parque urbano é uma área verde, com função ecológica, estética e de lazer, com uma extensão maior que as praças e jardins públicos.

O sistema de parques urbanos ou municipais pode ser de dois tipos: parques urbanos, dentro do perímetro urbano e parques rurais, situados dentro do Município. Os parques municipais guardam uma correlação especial com os problemas sociais, proporcionando, por exemplo, a queda do índice de criminalidade infantil (Chaddad, 2000).

Parque é todo espaço de uso público destinado à recreação de massa, qualquer que seja o seu tipo, cuja estrutura morfológica é auto-suficiente, isto é, não é diretamente 
influenciada em sua configuração por nenhuma estrutura construída em seu entorno. Dessa maneira, muitos dos atuais parques de pequeno porte não passam realmente de praças de vizinhança, sendo denominados parques em virtude da falta de consenso sobre o assunto entre os especialistas, dentro e fora do poder público (Macedo \& Sarata, 2003).

A Lei $\mathrm{n}^{0} 6.766$ de 19 de dezembro de 1979, dispunha sobre o parcelamento do solo urbano, em seu artigo $4^{\circ}$, inciso I, parágrafo $1^{\circ}$, preconizando que os loteamentos deviam possuir áreas destinadas a espaços livres de usos públicos, proporcionais à densidade de ocupação prevista para a gleba, não podendo ser inferiores a 35\% (trinta e cinco por cento) da gleba, exceto nos loteamentos maiores que $15.000 \mathrm{~m}^{2}$ (quinze mil metros quadrados), caso em que a percentagem poderia ser reduzida. No entanto, este dispositivo legal foi atualizado e alterado pela Lei $\mathrm{n}^{\circ} 9.785$ de 29 de janeiro de 1999, onde a porcentagem destes espaços não é mais quantificada e deve ser prevista pelo Plano Diretor ou aprovada por Lei Municipal para a zona em que se situem, que definirá os usos permitidos e os índices urbanísticos de parcelamento e ocupação do solo, incluindo, obrigatoriamente, as áreas mínimas e máximas de lotes e os coeficientes máximos de aproveitamento.

A finalidade dos espaços verdes livres é a plena expansão das funções de lazer e recreação. Recrear é voltar a criar energias. Todo homem deve ter possibilidade de escolher como recrear; há, portanto, necessidade de existir um sistema adequado de recreio para todas as classes e idades, compreendendo diversas alternativas. Um dos elementos fundamentais para recreio são os parques, que devem ser objeto de estudo dos governos federal, estadual e municipal. No âmbito federal, os elementos de recreio são constituídos de uma cadeia de parques nacionais (Chaddad, 2000).

O lazer abrange uma gama de possibilidades, tais como repousar, comer, fazer visitas, cinema, estádio, rádio, televisão, jornal, esportes, jardinagem, fotografia, música, entre outras; já a recreação é uma forma de transformar os momentos de folga para não se deixar cair no ócio. Dessa forma, o sistema de espaços livres públicos tem uma grande parcela de responsabilidade em fornecer opções para que a população encontre, nos momentos de lazer, muitas possibilidades de escolha para a sua recreação ao ar livre. 
É muito importante que o espaço livre exista e tenha, pelo menos, a potencialidade ecológica, deixando para a comunidade o direito de usufruí-lo da maneira que desejar. Tão embora as pessoas tenham dificuldade em reconhecer o papel ambiental desempenhado pelo verde urbano, elas se sentem agraciadas ao caminhar sob árvores, usufruir sua sombra, caminhar sobre gramados, observar plantas em florescimento, admirar o canto dos pássaros (Nucci, 1996).

A arborização exerce forte influência sobre o humor, as emoções e a satisfação das pessoas com o ambiente que as envolve. Essas influências subjetivas e psicológicas se constituem nos melhores benefícios que as árvores podem proporcionar à população urbana; uma expressão mais específica dessa idéia é a suposição de que árvores e outros elementos da natureza são psicologicamente saudáveis ao homem, e podem ajudar na redução de estresses associados à vida urbana (Schroeder ${ }^{5}$ citado por Freire, 2005).

Vários estudos pesquisados por Freire (2005) evidenciaram a relação entre falta de equipamentos de lazer e cultura e altos índices de violência; daí, a necessidade de atividades de lazer, cultura e esportes para a população, a fimm de inibir o uso de energias e tempo gastos em violências e no uso de drogas, apontando a arte, a cultura, a educação para a cidadania, o esporte e o lazer como elementos estratégicos para enfrentar e combater a violência. Há uma relação consistente entre arborização, lazer e redução da violência, não só em países do Hemisfério Norte, como no Brasil.

A implantação de sistemas de lazer pode contribuir para que um bairro ou um distrito municipal torne-se, ambiental e socialmente, um local melhor para se viver (Freire, 2005).

\subsection{7 Índice de Áreas verdes}

Os Sistemas de Áreas Verdes, em geral, são estruturados com base no Plano Diretor de Desenvolvimento Urbano que é o instrumento básico de definição do modelo

\footnotetext{
${ }^{5}$ SCHROEDER, H.W. Psycological value of urban trees: measurement, meaning, and imagination. In: NATIONAL URBAN FORESTRY CONFERENCE, 3., Orlando, Florida. Proceedings. Orlando: 5.ed., 1987. p.55-60.
} 
de desenvolvimento para Municípios com mais de vinte mil habitantes (Sanchotene, 2004).

À medida que a cidade cresce e se estrutura e é necessária a criação de mais áreas verdes e espaços de lazer, é preciso instituir um índice ou percentual que reflita uma qualidade de vida aceitável.

O índice de áreas verdes é aquele que expressa a quantidade de espaços livres de uso público, em $\mathrm{Km}^{2}$ ou $\mathrm{m}^{2}$, pela quantidade de habitantes que vive em uma determinada cidade. Então, neste cômputo, entram as praças, os parques e os cemitérios, ou seja, aqueles espaços cujo acesso da população é livre (Guzzo, 2003). O autor salienta que deveria ser trabalhado com um primeiro valor, que é em função da quantidade total das áreas existentes e um segundo, recalculado, que expresse quantas dessas áreas estão sendo realmente utilizadas, após uma avaliação do seu estado de uso e conservação. No entanto, este índice está intimamente ligado à função de lazer que desempenham ou que podem vir a desempenhar. Outro índice, que pode ser gerado, é o índice de cobertura vegetal em área urbana. Para obtenção desse índice, é necessário o mapeamento de toda cobertura vegetal de um bairro ou cidade e posteriormente quantificado $\mathrm{em}^{2}$ ou $\mathrm{Km}^{2}$. Conhecendo-se a área total estudada, também em $\mathrm{m}^{2}$ ou $\mathrm{km}^{2}$, chega-se posteriormente à porcentagem de cobertura vegetal que existe naquele bairro ou cidade. Se forem mapeadas somente as árvores, então esse índice expressará somente a cobertura vegetal de porte arbóreo.

Cavalheiro \& Del Picchia (1992) citam que o índice mais difundido no Brasil é o de que cada cidade deveria dispor de $12 \mathrm{~m}^{2}$ de área verde/habitante. Este índice teria sido desenvolvido pela Organização Mundial da Saúde (OMS), Organização das Nações Unidas (ONU) e Organização das Nações Unidas para a Alimentação e a Agricultura (FAO); porém, nunca aparecem as referências relativas aos autores e aos métodos para sua obtenção. Mais importante que uma definição numérica de um índice, são as associações que devem ser feitas, quanto às categorias de parques e/ou áreas verdes e suas distribuições espaciais na cidade, relacionando-os com o número de habitantes de 
cada região. Um estudo realizado por $\operatorname{Jantzen}^{6}$ (1973) destaca não só a preocupação com o índice de espaços livres por habitante, mas também sua distribuição por categorias, por faixas etárias, a área mínima do sítio, a distância da residência e a propriedade fundiária. Por exemplo, vizinhança até seis anos deve possuir $0,75 \mathrm{~m}^{2}$ de área verde por habitante, $150 \mathrm{~m}^{2}$ de área mínima, até 100 metros de distância da residência e ser de propriedade pública ou privada.

A comparação de índices de áreas verdes entre cidades pode ser um equívoco, pois o índice desacompanhado da definição de termo "área verde" não estabelece parâmetros para comparações (Cavalheiro \& Nucci, 1998).

Oliveira (1996) fez um levantamento das áreas públicas de São Carlos e obteve dois índices diferentes. O primeiro, denominado percentual de áreas verdes (PVA), foi estimado para grandes áreas da cidade que o autor chamou de unidades de gerenciamento. Neste índice entraram todas as áreas verdes públicas da cidade, independentemente da sua acessibilidade à população. Em seguida, foi calculado o índice de áreas verdes (IAV), considerando somente aquelas áreas verdes públicas de acesso livre para a população. Neste caso, os índices foram obtidos para setores da cidade. $\mathrm{O}$ índice de áreas verdes para a cidade como um todo também foi calculado e considerado um indicador de qualidade de vida da população, expressando a oferta de área verde "per capita".

\subsection{A Mineração no Brasil e no Estado de São Paulo}

A mineração é um dos setores básicos da economia do país, contribuindo de forma decisiva para o bem estar e a melhoria da qualidade de vida das presentes e futuras gerações. É fundamental para o desenvolvimento de uma sociedade equânime, desde que seja operada com responsabilidade social, estando sempre presentes os preceitos do desenvolvimento sustentável (Farias, 2002).

\footnotetext{
${ }^{6}$ JANTZEN, E et al. Grunflachenbedar Parkanlagen. Hamburg: Conf. Dir. D. P. J. R. F. A., 1973. 43p.
} 
A mineração provê a humanidade de um elevado número de matérias-primas e insumos, imprescindíveis à manutenção da vida, ao conforto e ao progresso da civilização, na construção (coberturas, revestimento), na agricultura (fertilizantes, embalagens), na medicina (seringa, termômetro, medicamentos), na ciência e tecnologia (computadores, máquina fotográfica), nos transportes (avião, carro), nas comunicações (antenas, rádios, telefones), nos manufaturados (lâmpadas, arames, encanamentos), nos bens de consumo (vidraria, cosméticos) e nas artes (instrumentos musicais, materiais para pintura). O conceito de "riqueza" ainda está embutido em alguns metais e gemas, mas a grande maioria dos minérios tem relevante importância social. A simples areia para construção ou as argilas, que suprem as olarias produtoras de tijolos e telhas, têm baixo valor econômico, porém elevada significação social (Tanno \& Sintoni, 2003).

$\mathrm{O}$ consumo de agregados, medido em $\mathrm{m}^{3} /$ habitante/ano (consumo "per capita"), pode ser considerado como um indicador de qualidade de vida urbana. A atividade de mineração não gera muitos empregos diretos, mas é importantíssima como atividade básica de suporte para as indústrias de transformação e para a construção civil, setores responsáveis por maior absorção de mão-de-obra. A implantação dos empreendimentos de mineração normalmente acarreta investimentos em infra-estrutura, transporte, energia e serviços, funcionando como pólo estratégico de desenvolvimento, gerando empregos, impostos e compensações financeiras para os Municípios, sendo um fator importante de descentralização da economia (Tanno \& Sintoni, 2003).

O Brasil possui uma expressiva dotação mineral, que se traduz na produção de mais de 70 tipos de substâncias minerais, sendo 21 do grupo dos metálicos, 45 dos minerais não-metálicos e 3 dos energéticos, além de uma grande variedade de gemas (Tanno \& Sintoni, 2003; Departamento Nacional de Produção Mineral - DNPM, 2004).

No ano de 2003, o resultado do produto da indústria extrativa mineral brasileira, incluindo petróleo e gás natural alcançou um montante da ordem de US\$ 14,1 bilhões, que correspondeu a $2,9 \%$ do PIB. Contudo, a real contribuição do setor mineral à economia brasileira pode ser amplamente mensurada considerando-se o efeito multiplicador obtido pela agregação de valor às matérias-primas minerais decorrentes dos processos industriais. Portanto, sobre esse enfoque, o produto da indústria de 
transformação mineral alcançou US\$ 41,6 bilhões, correspondendo a 8,4\% do PIB. Em 2003, o setor mineral participou no total das exportações brasileiras com aproximadamente $23,7 \%$, resultado esse 0,2 pontos percentuais superior à participação registrada em 2002 (DNPM, 2004).

No mercado brasileiro, constata-se que a indústria mineral de não-metálicos expandiu-se substancialmente ao longo das últimas três décadas, com destaque especial para a expressiva produção dedicada ao consumo interno de agregados, argilas, rochas carbonáticas, rochas fosfáticas e água mineral (Tanno \& Sintoni, 2003). A aceleração histórica do crescimento urbano no Estado de São Paulo e a geologia dos terrenos paulistas, levaram à produção preferencial de depósitos de matérias-primas para uso na construção civil, que representam mais de $90 \%$ do valor da produção mineral do Estado. O volume da produção desses bens minerais é tão expressivo, que São Paulo insere-se entre os grandes produtores de bens minerais do País, a partir da extração, em território paulista, de algo em torno de 25 variedades de substâncias minerais de natureza nãometálica. Especificamente quanto aos bens minerais de uso na construção civil, destacam-se, face ao volume e valor de produção atingida, as matérias-primas in natura (areia, brita e rochas ornamentais), argilas para cerâmica vermelha e rochas carbonáticas para fabricação de cimento e cal (Mello et al, 1998).

A mineração distribui-se no território paulista controlada por um arcabouço geológico definido por dois grandes domínios geológicos, o Embasamento Cristalino e a Bacia Sedimentar do Paraná (Anexo C). O Embasamento Cristalino, de idade précambriana (superior a 570 milhões de anos), ocupa o sul, a faixa litorânea e o leste do Estado, com pequena exposição no extremo nordeste. A Bacia Sedimentar do Paraná, de idade fanerozóica (inferior a 570 milhões de anos), constitui cerca de 70\% da área do Estado. Sobrepondo esses dois domínios, ocorrem bacias sedimentares menores e mais jovens, bem como os sedimentos (areias e cascalhos) ao longo dos rios atuais. No Embasamento Cristalino, ocorrem as principais extrações de rocha para brita e rochas ornamentais, areias para a construção civil, calcários (cimento e cal) e dolomitos. Na Bacia Sedimentar do Paraná, são lavradas, entre outras substâncias minerais, rochas para brita (basaltos), areias para construção civil, areias silicosas para fins industriais (vidro e 
fundição), calcários dolomitos para corretivos de solo, rochas fosfáticas para fertilizantes (maciços alcalinos) e argilas para cerâmica vermelha. Nos ambientes sedimentares, as argilas para cerâmica branca, refratária e vermelha e a areia para construção civil são intensamente extraídas, contando-se, mais recentemente, com a lavra de turfa para uso agrícola. As pedras britadas, a areia e cascalho, a água mineral, as argilas comuns e plásticas e o calcário são os cinco bens minerais mais produzidos no Estado de São Paulo (Tanno \& Sintoni, 2003). As figuras 1 a 4 apresentam os pólos produtores de bens minerais no Estado de São Paulo.

A produção de agregados para a construção civil está disseminada por todo território nacional, na grande maioria de controle familiar. O número de empresas que produzem pedra britada é da ordem de 450 e são responsáveis por cerca de 15.000 empregos diretos. Cerca de 2.000 empresas se dedicam à extração de areia, gerando cerca de 45.000 empregos diretos. No ano de 2003, o Estado de São Paulo respondeu por $34,8 \%$ da produção nacional de agregados para a construção civil, seguido por Minas Gerais (12,3\%), Rio de Janeiro (10,8\%), Paraná (7,6\%), Rio Grande do Sul $(6,8 \%)$ e Santa Catarina (3,5\%). A Região Metropolitana de São Paulo é o maior mercado consumidor de agregados do país. Outros grandes mercados são as Regiões Metropolitanas de Belo Horizonte, Rio de Janeiro, Curitiba e Porto Alegre e as Regiões de Campinas, Sorocaba e Baixada Santista no Estado de São Paulo e Maringá-Londrina no Estado do Paraná (Valverde, 2004). 

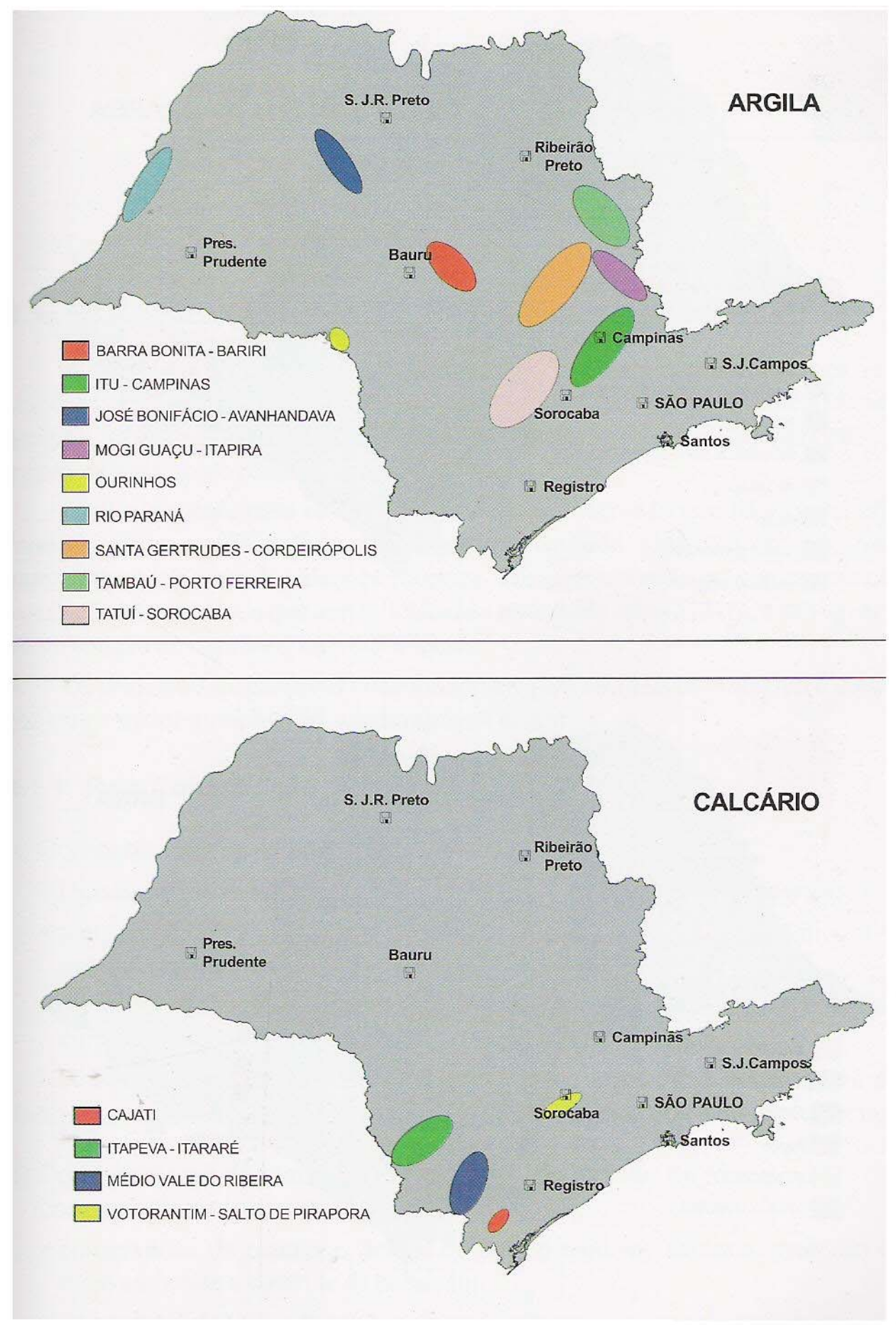

Fonte: Tanno \& Sintoni (2003).

Figuras 1 e 2 - Pólos produtores de argila e calcário no Estado de São Paulo 


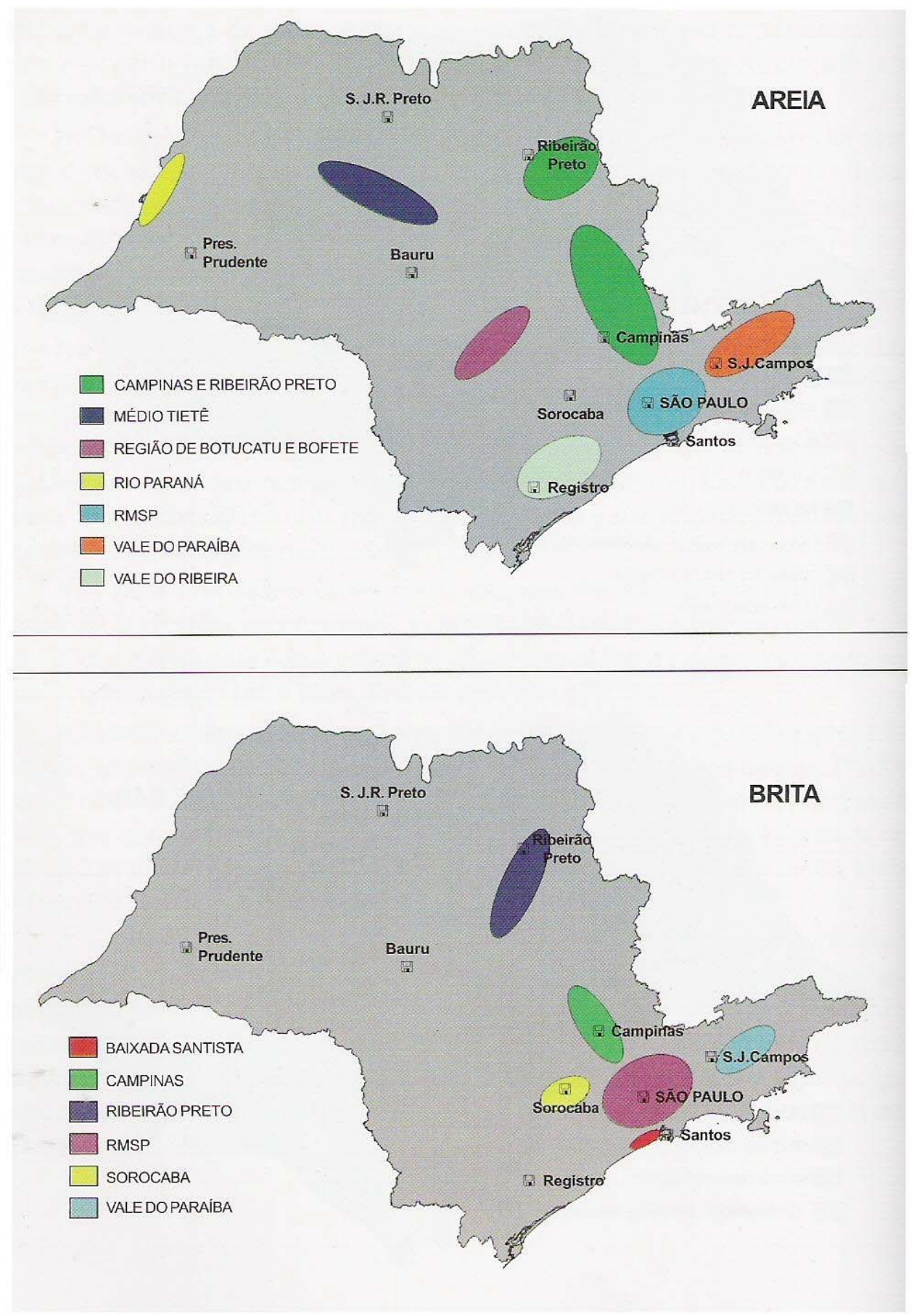

Fonte: Tanno \& Sintoni (2003).

Figuras 3 e 4 - Pólos produtores de areia e brita no Estado de São Paulo 


\subsection{Impactos Ambientais da Mineração no Estado de São Paulo}

Bitar (1997) denomina "externalidades" um conjunto de efeitos indesejados provocados pela mineração. Estas externalidades são alterações ambientais, conflitos de uso do solo, depreciação de imóveis circunvizinhos, geração de áreas degradadas e transtornos ao tráfego urbano.

Dias (2001) divide a avaliação dos impactos ambientais da mineração, de acordo com o meio afetado, ou seja, físico, biótico e antrópico. A maior parte dos efeitos da mineração, no entanto, atinge primeiramente o meio físico, sendo os impactos sobre os meios biótico e antrópico muitas vezes decorrentes dos primeiros. Os impactos sobre o meio físico subdividem-se, tradicionalmente, em impactos sobre as águas, que inclui aspectos de poluição das águas e drenagem superficial de minas; resíduos sólidos, que trata do seu gerenciamento, com ênfase nos estéreis e rejeitos; impactos sobre a atmosfera, incluindo poluição do ar, ruídos e sobrepressão acústica; e vibrações no solo causadas pelo desmonte por explosivos. As atividades de mineração afetam os ecossistemas (meio biótico), principalmente pela alteração ou destruição de habitats, o que, por sua vez, resulta em danos à fauna. A falta de um adequado gerenciamento das águas de drenagem das minas, em geral, pode provocar desde o assoreamento de rios até a contaminação do lençol freático e das águas superficiais, atingindo, num primeiro momento, a fauna aquática e a flora irrigada por estas águas, refletindo-se, em seguida, por toda a cadeia alimentar. A poluição do ar é capaz de causar danos a florestas situadas a distâncias consideráveis dos pontos de emissão. Os ruídos e as vibrações transmitidas pelo ar ou pelo solo, provenientes das operações de desmonte de rochas por explosivos, transporte e britagem, entre outras, podem causar prejuízos à fauna, seja afugentando-a das proximidades, seja causando tensão que venha a se refletir na capacidade de procriação ou de cuidar de suas crias. Os ecossistemas podem ser ainda afetados pela mineração através da destruição dos habitats por meio do desmatamento de áreas para a implantação da mina, pilhas de estéril, pátios de manobras, vias internas de circulação, bacias de rejeito e usinas de tratamento de minérios. Outra forma direta de alteração ou 
destruição de habitats é o desvio ou barramento de rios, seja para obtenção de água para as atividades de lavra ou tratamento de minérios, seja para permitir o acesso a depósitos minerais subaquáticos. Os impactos sobre o meio antrópico são usualmente classificados em: sociais, econômicos e culturais. Os principais impactos antrópicos sociais são: impacto visual; alteração da dinâmica demográfica; desconforto ambiental; remoção de pessoas; impactos sobre a saúde; qualificação de mão-de-obra; alteração das formas de uso do solo. Os principais impactos antrópicos econômicos são: aumento da demanda por serviços sociais; alteração das opções de uso do solo; aumento da demanda por infra-estrutura; aumento da oferta de empregos; aumento local de preços de bens e serviços; incremento da atividade econômica; substituição de atividades econômicas; indução ao desenvolvimento regional; diminuição da produtividade dos ecossistemas; aumento da arrecadação tributária. Os principais impactos antrópicos culturais são: perda de patrimônio; alteração das relações socioculturais.

Do controle dos impactos gerados pelas diversas atividades do homem nasceu a idéia de convivência amigável do ser humano com o seu meio e, conseqüentemente, o conceito de desenvolvimento sustentável. Sendo assim, a sociedade vem, de uma maneira bastante significativa e importante, mobilizando-se, a fim de difundir e praticar o controle dos impactos ambientais. Portanto, a implantação e desenvolvimento de atividades econômicas devidamente planejadas e operadas, observando, respeitando e interagindo com o meio é a única maneira de promover o bem-estar social juntamente com a manutenção do meio ambiente (Dias, 2001).

\subsection{Atividades de recuperação de áreas degradadas}

Assim como em qualquer outra temática relacionada à busca de soluções para problemas urbanos e ambientais, a recuperação de áreas degradadas tem envolvido abordagens interdisciplinares, reunindo e integrando o conhecimento de diferentes campos do conhecimento humano. Os procedimentos e atividades que envolvem a recuperação de áreas degradadas por mineração têm variado de acordo com cada caso ou experiência realizada, compreendendo basicamente, o planejamento da recuperação, a 
execução do plano de recuperação elaborado e a realização do monitoramento e a manutenção das medidas implementadas. A primeira atividade compreende a identificação e a caracterização dos processos de degradação atuantes e a análise de suas conseqüências ambientais, traduzindo quantitativa ou qualitativamente o grau da degradação existente e estimando a dimensão dos esforços técnicos e econômicos que deverão ser alocados na recuperação. A avaliação deve contemplar, entre outros aspectos, a análise dos riscos à saúde e segurança das comunidades eventualmente afetadas, bem como os usos do solo circunvizinhos. A consulta a essas comunidades é fundamental nesta atividade, de modo a obter informações importantes para uma avaliação completa da degradação e seu histórico (Bitar, 1997).

As atividades básicas no planejamento da recuperação geralmente incluem a definição dos objetivos, o estabelecimento do uso futuro da área, a elaboração de um plano de recuperação e o compromisso de recuperação da área pelo empreendedor. A tomada de decisão sobre o uso futuro da área deve levar em conta a relevância técnica, social e legal das alternativas propostas, bem como os custos e prazos envolvidos na sua implementação. Estudos desenvolvidos em vários países revelam que os custos das medidas de recuperação são sensivelmente reduzidos quando, desde o início da lavra, estabelece-se um projeto de recuperação da área, que contemple a remoção e o armazenamento da cobertura vegetal e da camada superficial do solo; aterros, material de empréstimo, contenção de taludes, aplainamentos e acabamento final das frentes de lavra; reposição da camada de solo fértil e revegetação. O uso de critérios arquitetônicos na elaboração e execução do plano de lavra, também deve ser considerado no planejamento da recuperação da área afetada. Com isso, é possível reduzir o desconforto humano em relação ao resultado final da mineração e permitir que o uso seqüencial do espaço ocorra quase naturalmente, ao final da atividade extrativa (Bitar, 1997).

A escolha das medidas a serem implementadas na recuperação de áreas degradadas requer análise cuidadosa das alternativas tecnológicas disponíveis e da provável eficácia que as medidas terão na correção ou estabilização da degradação. Há três grandes conjuntos de alternativas aplicadas à recuperação de áreas degradadas: revegetação, geotecnologias e remediação, visando sobretudo a estabilidade biológica, 
física e química do ambiente, respectivamente. Na prática, as medidas são comumente aplicadas de modo combinado. Os métodos de revegetação envolvem desde a fixação localizada de espécies vegetais até a implantação de reflorestamentos extensivos, tanto para fins de preservação ou conservação ambiental quanto para objetivos econômicos, incluindo a geração de condições propícias ao repovoamento da fauna e à regeneração de ecossistemas primitivos ou originais. Os métodos de fundamentação geotécnica podem envolver, desde a execução de medidas simples, até obras de engenharia relativamente complexas. As obras geotécnicas visam a estabilização física do ambiente. Terraplenagem, sistemas de drenagem e bacia de contenção de sedimentos, barragens, contenção de taludes, são possíveis procedimentos geotécnicos. Os métodos de remediação envolvem o uso de técnicas de tratamento que visam eliminar, neutralizar ou transformar elementos ou substâncias contaminantes presentes no ambiente e, assim, alcançar a estabilidade química do ambiente. As medidas de recuperação executadas requerem vistorias e inspeções periódicas, visando manter as condições necessárias ao cumprimento dos objetivos preestabelecidos no plano de recuperação. Resultados insatisfatórios podem exigir desde a reavaliação da área degradada e a reformulação das medidas executadas até, se necessário, sua complementação ou substituição (Bitar, 1997).

\subsection{Instrumentos Legais e institucionais incidentes sobre as áreas sujeitas às atividades de extração e recuperação de substâncias minerais}

\subsubsection{Das atividades de extração das substâncias minerais}

O Decreto-Lei no 227 de 28 de fevereiro de 1967 (Código de Mineração), conjugado com a legislação correlata, é o instrumento legal básico que dispõe sobre as formas e condições de habilitação e execução das atividades de pesquisa e lavra de substâncias minerais, sendo sua aplicação de alçada do Departamento Nacional de Produção Mineral (DNPM), órgão do Ministério de Minas e Energia (MME), que conta com unidades regionais nas capitais dos Estados brasileiros (Tanno \& Sintoni, 2003). 
Tais atividades devem estar, obrigatoriamente, enquadradas em uma das seguintes formas legais de aproveitamento, estabelecidas de acordo com a substância mineral a ser extraída:

- Regime de Autorização: representado pelo Alvará de Autorização de Pesquisa, outorgado a pessoa física ou jurídica, para realizar as pesquisas geológicas dentro da área com extensão máxima de 50,1.000 ou 2.000 hectares, de acordo com a substância e a região e dentro do prazo máximo de 3 anos.

- Regime de Concessão: representado pela Portaria de Lavra, outorgada a pessoas jurídicas, como conseqüência do cumprimento de todas as disposições legais e administrativas relativas ao regime de autorização, especialmente a aprovação do Relatório Final de Pesquisa e do Plano de Aproveitamento Econômico da jazida no DNPM e da emissão das Licenças Prévia e de Instalação pelo órgão ambiental competente, além de assentimento de outros órgãos competentes, quando em área de sua jurisdição.

- Regime de Licenciamento: representado pela licença do DNPM, facultada exclusivamente ao proprietário do solo ou a quem dele tiver expressa autorização, depende em primeiro lugar da licença específica expedida pelo Município, além do licenciamento ambiental estadual. A área máxima para o licenciamento está definida em lei, como sendo de 50 hectares, enquanto que a determinação do prazo de vigência e de outras condições é prerrogativa do Município. O regime de licenciamento é aplicável a um grupo restrito de substâncias minerais, cujo aproveitamento pode ser feito sem submissão a processo industrial de beneficiamento e, ainda, que a sua utilização não seja como matéria-prima destinada à indústria de transformação.

- Regime de extração, exclusivo para órgãos da administração direta ou autárquica da União, dos Estados ou dos Municípios: a área máxima permitida para registro é de 5 hectares, a extração deve se dar por prazo determinado, o produto da lavra deve ser utilizado exclusivamente em obras públicas e a comercialização das substâncias extraídas é vetada; as substâncias minerais admitidas por este registro são exclusivamente as de emprego imediato na construção civil, definidas em legislação. 
- Regime de permissão de lavra garimpeira: contempla as atividades de extração mineral consideradas garimpáveis, como ouro, diamante, cassiterita, entre outros; a área máxima permitida é de 50 hectares, para pessoa física ou firma individual e de 1.000 hectares, para cooperativa de garimpeiros, sendo o prazo máximo de validade do título igual a 5 anos.

- Regime de monopolização: enquadra as substâncias minerais objeto de monopólio estatal, como petróleo, gás natural, outros hidrocarbonetos fluidos e minerais e minérios nucleares; a pesquisa e o aproveitamento destas substâncias estão subordinados a leis especiais que condicionam sua execução direta ou indireta, pelo Governo Federal, e estão incursos em áreas de competências de outros órgãos específicos, vinculados ao MME, que não o DNPM (Tanno \& Sintoni, 2003).

A área requerida pelo minerador para extração a esse Departamento recebe o nome de poligonal DNPM, formada obrigatoriamente por segmentos de retas com orientação Norte-Sul e Leste-Oeste verdadeiros com um dos seus vértices amarrado a um ponto definido por coordenadas geográficas e os seus lados por comprimentos e rumos verdadeiros. Esta poligonal pode englobar diversas propriedades, podendo ser, muitas vezes, o proprietário da área e o titular do direito minerário, diferentes.

$\mathrm{O}$ proprietário do solo onde se localiza a mina tem direito à participação nos resultados da lavra, no valor equivalente a $50 \%$ do valor apurado no cálculo da Compensação Financeira pela Exploração de Recursos Minerais - CEFEM (Tanno \& Sintoni, 2003).

A CEFEM, estabelecida pela Constituição de 1988, em seu Art. 20, § 1º é devida pelas mineradoras, aos Estados, ao Distrito Federal, aos Municípios e aos órgãos da administração da União, como contraprestação pela utilização econômica dos recursos minerais em seus respectivos territórios. Ao DNPM, compete baixar normas e exercer fiscalização sobre a arrecadação da CEFEM (Lei $\mathrm{n}^{\circ}$ 8.876/94, art. $3^{\circ}$, inciso IX). A compensação financeira é calculada sobre o valor do faturamento líquido, obtido por ocasião da venda do produto mineral. Os recursos da CEFEM são distribuídos da seguinte forma: $12 \%$ para a União (DNPM e Instituto Brasileiro do Meio Ambiente e 
dos Recursos Naturais Renováveis - IBAMA); 23\% para o Estado onde for extraída a substância mineral; 65\% para o Município produtor. Os recursos originados da CEFEM, não poderão ser aplicados em pagamento de dívida ou no quadro permanente de pessoal da União, dos Estados, Distrito Federal e dos Municípios. As respectivas receitas deverão ser aplicadas em projetos, que direta ou indiretamente revertam em prol da comunidade local, na forma de melhoria da infra-estrutura, da qualidade ambiental, da saúde e educação.

\subsubsection{Da recuperação das áreas degradadas pela mineração}

A recuperação de áreas degradadas tem sido implantada em diferentes países como importante instrumento de política pública na área ambiental. As abordagens são variadas, mas perseguem o mesmo objetivo de assegurar a correção dos impactos ambientais considerados negativos e importantes.

A conscientização ambiental nacional e internacional, junto com o acúmulo do passivo ambiental causado pelas atividades minerárias têm resultado em pressões crescentes sobre o governo e as empresas mineradoras para implementar a recuperação ambiental efetiva. Hoje, o Brasil se encontra no meio de uma evolução de leis ambientais, de regulamentos, de atitudes empresariais e práticas de recuperação. Embora os processos de lavra, com os seus conseqüentes problemas ambientais, as metas de recuperação e as práticas disponíveis se assemelhem àqueles existentes em outras partes do mundo, o desafio é selecionar e adaptar os protocolos de recuperação às situações ambientais específicas do Brasil (Toy \& Griffith, 2002a).

No Brasil, o tema "recuperação de áreas degradadas", apesar de algumas referências anteriores em âmbito federal, foi previsto somente na Lei 6.938/81 (dispõe sobre a Política Nacional do Meio Ambiente) no inciso VIII ("recuperação de áreas degradadas"), do artigo $2^{\circ}$, como um dos seus princípios. No artigo $4^{\circ}$, inciso VII, a Política Nacional do Meio Ambiente visa "a imposição, ao poluidor e ao predador, da obrigação de recuperar e/ou indenizar os danos causados e, ao usuário, da contribuição pela utilização de recursos ambientais com fins econômicos". 
No artigo $9^{\circ}$, incisos III e IV, a Lei 6.938/81, preconiza a "avaliação de impactos ambientais" e o "licenciamento e a revisão de atividades efetiva ou potencialmente poluidoras" como instrumentos da Política Nacional do Meio Ambiente e compete esse licenciamento a órgão estadual integrante do Sistema Nacional do Meio Ambiente (SISNAMA) e do IBAMA. No artigo 14, estabelece que o não cumprimento às medidas de preservação e correção dos danos à qualidade ambiental implica em multa, perda de restrição de incentivos fiscais e perda de suspensão de participação em linhas de financiamento em estabelecimentos de crédito: “o Ministério Público dos Estados terá legitimidade para propor ação de responsabilidade civil e criminal por danos causados ao meio ambiente".

Com isso, em 1986, todos os empreendimentos poluidores, inclusive empreendimentos mineiros foram obrigados a ter licenciamento ambiental para sua instalação e operação. O Artigo $2^{\circ}$ da Resolução CONAMA n ${ }^{\circ} 01$ de 86, estabelece a apresentação do Estudo de Impacto Ambiental/Relatório de Impacto do Meio Ambiental (EIA/RIMA) e "aprovação pelo órgão estadual competente e pelo IBAMA em caráter supletivo". Quando a atividade for de competência federal, o EIA/RIMA será submetido à aprovação do IBAMA. A Resolução CONAMA nº 237/97 complementa a Resolução CONAMA $n^{\circ} 01 / 86$, revisando e aprimorando os procedimentos e critérios utilizados no licenciamento ambiental. Estas Resoluções dão competência aos Municípios para interferência no licenciamento ambiental, que passaram a incorporar o assunto recuperação em seus quadros legais, através de instrumentos de planejamento e gestão como Plano Diretor, Lei de Uso e Ocupação do Solo e Código Florestal Municipal.

A Constituição da República Federativa do Brasil, promulgada em 05 de outubro de 1988 dedica o Capítulo VI ao Meio Ambiente e estabelece no Artigo 225 que "todos têm direito ao meio ambiente ecologicamente equilibrado, bem de uso comum do povo e essencial à sadia qualidade de vida, impondo-se ao poder público e à coletividade o dever de defendê-lo e preservá-lo para as presentes e futuras gerações". No inciso IV do parágrafo $1^{\circ}$ incube ao Poder Público, a fim de assegurar a afetividade do direito ao meio ambiente, "exigir, na forma da lei, para instalação de obra ou atividade potencialmente causadora de significativa degradação do meio ambiente, estudo prévio de impacto 
ambiental, a que se dará publicidade". No parágrafo $2^{\circ}$ determina, especificamente, que as áreas degradadas pela mineração devem ser recuperadas, através do seguinte texto: "aquele que explorar recursos minerais fica obrigado a recuperar o meio ambiente degradado, de acordo com solução técnica exigida pelo órgão público competente, na forma da lei" e no parágrafo $3^{\circ}$ relata que "as condutas e atividades consideradas lesivas ao meio ambiente sujeitarão os infratores, pessoas físicas ou jurídicas, a sanções penais e administrativas, independentemente da obrigação de reparar os danos causados".

Castro (1998) atribui o uso da expressão "recursos minerais" a uma falha técnica dos constituintes de 1988, que particularizam a recuperação à extração mineral. A Constituição do Estado de Minas Gerais reproduz o mesmo texto com a expressão "recurso ambiental" em seu parágrafo $4^{\circ}$ do artigo 214: "quem explorar recurso ambiental fica obrigado a recuperar o meio ambiente degradado, na forma da lei".

No Direito Ambiental (Castro, 1998), a obrigação de reparar a lesão do meio ambiente não depende da culpa, mas sim da existência do dano. Este princípio baseia-se na "responsabilidade objetiva", que se baseia no exercício de certas atividades. A poluição causada pelo dano ambiental acaba sendo uma apropriação pelo poluidor dos direitos de outras pessoas, pois a emissão do poluente representa um confisco do direito do outro de respirar o ar puro, beber água saudável e viver com tranqüilidade.

Em 1989, o Decreto Federal no 97.632, de 10 de abril, regulamenta o artigo $2^{\circ}$, inciso VIII da Lei da Política Nacional do Meio Ambiente e preconiza em seu artigo $1^{\circ}$ que os empreendimentos mineiros devem apresentar nos seus Estudos de Impacto Ambiental, o Plano de Recuperação de Áreas Degradadas (PRAD). Para os empreendimentos já existentes, o PRAD deveria ser apresentado em 180 dias. A recuperação (artigo $3^{\circ}$ ) "deverá ter por objetivo o retorno do sítio degradado a uma forma de utilização, de acordo com um plano preestabelecido para o uso do solo, visando a obtenção de uma estabilidade do meio ambiente”. Para tanto, a Resolução da Secretaria do Meio Ambiente - SMA nº 18/89 regulamenta e determina a apresentação de Plano de Recuperação dos empreendimentos minerários em processo de licenciamento, estabelecendo um roteiro básico para a elaboração do PRAD. 
A Constituição do Estado de São Paulo, de 1989, no Capítulo IV do Meio Ambiente, dos Recursos Naturais e do Saneamento, na Seção I, do Meio Ambiente, estabelece que a licença ambiental para a exploração de recursos naturais de qualquer espécie, será sempre precedida da aprovação do EIA e seu respectivo relatório. No Artigo 194, reproduz o mesmo texto da Carta Magna em seu Artigo 225, porém a substituição de "recursos minerais" por "recursos naturais": "aquele que explorar recursos naturais fica obrigado a recuperar o meio ambiente degradado, de acordo com a solução técnica exigida pelo órgão público competente, na forma da lei”. Obriga, no parágrafo único, a recuperação, pelo responsável, da vegetação adequada nas áreas protegidas e no artigo 195, promulga sanções penais e administrativas aos infratores do meio ambiente.

As Resoluções CONAMA no 09/90 e n ${ }^{\circ}$ 10/90 resolvem que o empreendimento mineiro deve submeter seu pedido de licenciamento ambiental ao órgão estadual competente ou ao IBAMA, em três etapas: Licença Prévia - LP, Licença de Instalação LI e Licença de Operação - LO.

O Estado de São Paulo promulga diversos instrumentos legais que regulamentam e disciplinam o licenciamento ambiental no Estado: Resoluções SMA no 26/93, SMA n ${ }^{\circ}$ 42/94 e SMA no 04/99. Os órgãos licenciadores paulistas pertencentes à Secretaria do Meio Ambiente, articulados para análise são Departamento de Avaliação de Impacto Ambiental/Coordenadoria de Planejamento Ambiental (DAIA/CPLA), Departamento Estadual de Proteção aos Recursos Naturais (DEPRN), Companhia de Tecnologia de Saneamento Ambiental (CETESB) e Departamento de Uso do Solo Metropolitano (DUSM), quando a área localizar-se na Região Metropolitana de São Paulo.

Em 1998, a Lei no 9605/98 (Lei de Crimes Ambientais) dispõe sobre as sansões penais e administrativas derivadas de condutas e atividades lesivas ao meio ambiente, promulgando em seu artigo 55 que "executar pesquisa, lavra ou extração de recursos minerais sem a competente autorização, permissão, concessão ou licença, ou em desacordo com a obtida", penaliza o infrator em seis meses a um ano de detenção e multa; "nas mesmas penas incorre quem deixa de recuperar a área pesquisada ou explorada, nos termos da autorização, permissão, licença, concessão ou determinação do 
órgão competente" (parágrafo único). Tal regulamento penaliza claramente o funcionamento do empreendimento sem licença ambiental.

É imprescindível lembrar que a elaboração de qualquer projeto que vise a instalação e operação de uma atividade de extração mineral, englobando seus impactos ambientais e medidas mitigadoras deve englobar aspectos instituídos em outros documentos legais importantíssimos como:

- Lei no 4771 de 15/09/1965: Código Florestal

- Decreto no 24.643 de 10/07/1934: Código de Águas

- Lei n 9433 de 08/01/1997: Política Nacional de Recursos Hídricos

- Lei no 9985 de 18/06/2000: Sistema Nacional de Unidades de Conservação da Natureza.

- Resoluções CONAMA no 302 e no 303 de 20/03/2002: dispõe sobre parâmetros, definições e limites de Áreas de Preservação Permanente.

Antes de 1986 (década de 80) havia um descontrole geral nos empreendimentos minerários e na recuperação de tais áreas. As leis tinham pouca influência no licenciamento e a recuperação das áreas degradadas eram pouco mencionadas e questionadas. Os órgãos regulamentadores estavam minimamente capacitados na regularização e fiscalização dos impactos ambientais e na análise das medidas mitigadoras para tais impactos.

As forças motivadoras primárias para se fazer a recuperação vinha das organizações internacionais de financiamento, que exigiam a proteção e a recuperação ambiental das áreas mineradas para liberar o financiamento e dos Conselhos Municipais de Defesa Ambiental, que podiam fazer pressão política sobre os governos locais (Toy \& Griffith, 2002a).

Na década de 90 do século XX e no início do século XXI, a regulamentação para obrigatoriedade da recuperação das áreas degradadas proporcionou e proporciona aos órgãos públicos, um maior controle aos empreendimentos licenciados. 
No futuro, essa regulamentação ficará mais exigente, a fiscalização será mais freqüente e rigorosa e o cumprimento das leis será cobrado de pequenos e grandes empreendimentos.

A reabilitação de áreas degradadas, vai mais além do que uma simples formalidade legal e se fundamenta na obrigação de reparar o dano causado ao meio ambiente. Este dano pode ter origem, inclusive, em atividade permitida por lei, como é o caso da mineração e visa repor a área ao seu estado original. A obrigação da reabilitação prevista na legislação não é repor fisicamente a área exatamente como era antes, mas repor a área em uma situação de normalidade e estabilidade (Castro, 1998).

\subsection{Possíveis usos do solo para antigas áreas de mineração}

A exploração dos recursos minerais está diretamente relacionada à recuperação do sítio degradado, que sob a forma da lei, deve seguir uma solução técnica coerente, plausível e viável ao local e ao seu entorno.

Em geral, a melhor recuperação é encontrada nas empresas grandes, pois elas possuem os recursos financeiros, o pessoal e os conhecimentos necessários para produzir uma recuperação ao nível de padrões internacionais (Toy \& Griffith, 2002b).

$\mathrm{O}$ investimento realizado na área ambiental por grandes empresas de mineração, como a Companhia Vale do Rio Doce é bastante alto e engloba os inúmeros programas e projetos desenvolvidos nas diversas unidades da empresa e junto às comunidades vizinhas aos empreendimentos. Os dispêndios em ações ambientais, em 2002, por exemplo, atingiram a soma de $\mathrm{R} \$ 78$ milhões, sendo investidos $\mathrm{R} \$ 23$ milhões em reabilitação de áreas já mineradas. O Programa de Gestão Ambiental é responsável pelo processo de certificação ambiental e outras ações ambientais desenvolvidas pela empresa, que visam o aprimoramento da qualidade ambiental das suas atividades operacionais (Brasil Mineral, 2003).

Na mineração, é necessário pensar o projeto desde o seu planejamento até sua desativação, quando normalmente está associado o plano de recuperação ambiental de uma área que foi degradada pelo empreendimento. Numa área urbana, toda gleba passa 
por uma série de ocupações diferentes ao longo do tempo. Isso faz parte da dinâmica urbana, na qual a mineração também se insere, já que se trata do uso temporário de determinado sítio, dentro de um espaço urbano (ou rural) maior, que depois será sucedido por algum outro uso. Este uso futuro do local deve ser o ponto central dos projetos de recuperação (Sanchez, 1995).

Este mesmo autor (1995) cita casos norte-americanos e europeus, datados das décadas de 80 e 90, de usos para áreas pós atividades minerárias:

-EUA: mina de calcário, transformada num campo de golfe;

-EUA: mineração de areia, transformada numa área de uso residencial, com a construção de 190 residências, onde foram utilizadas não só a área da cava, mas a própria bacia de rejeitos;

-EUA: mina de calcário, utilizada para fins agrícolas, numa área de 243 hectares, com a particularidade de que a atividade de mineração continua operando; uma parte da área foi recuperada e outra continua sendo utilizada, de modo que cerca de 8 hectares são recuperados por ano; é um processo de recuperação concomitante ao desenvolvimento da atividade de mineração

-EUA: pedreira de calcário, ainda em funcionamento, deu origem a um centro comercial, localizado em terreno de propriedade da mineradora.

-Alemanha: construção de novo paço municipal, em área de uma antiga pedreira;

-Inglaterra: construção de aterro sanitário, em uma antiga pedreira e uma área de um parque de diversões, em outra;

-Inglaterra: recuperação de uma área com finalidade mista, de cunho ecológico e recreativo.

Para Willians et al (1990), os possíveis usos do solo para antigas áreas de mineração são:

a) Reflorestamento com espécies nativas para manutenção da vida selvagem, incluindo lagos, açudes, córregos, fauna e flora locais;

b) Reflorestamento de várzeas e banhados com espécies nativas; 
c) Reflorestamento comercial com espécies exóticas para a produção de celuloses, resinas, tanina, metanol, lenha, mourões, postes, madeira serrada para móveis e construção civil;

d) Parques, áreas de lazer, entretenimento, recreação;

e) Cultivo e colheita de plantas para alimento humano e animal;

f) Pastagem para animais;

g) Represamento de água para geração de energia elétrica, irrigação, fornecimento de água urbana e industrial;

h) Piscicultura;

i) Área urbana, residencial, comercial, serviços públicos;

j) Área industrial;

k) Resíduos urbanos e industriais, sólidos e líquidos: tratamento ou confinamento.

Ricciardi \& Sanchez (2004) apresentam vários exemplos de antigas áreas de mineração de agregados para construção civil em São Paulo, que hoje são utilizados para finalidades diversas:

a) reabilitação para aterros de resíduos inertes:

-pedreira Itaquera, localizada na Zona Leste do Município de São Paulo, começou como pedreira de cantaria em meados do século XIX; no início dos anos 90 foi selecionada como área para disposição de resíduos inertes; as operações de lavra de granito encerraram-se em agosto de 1999 e o aterro de resíduos inertes começou a operar em outubro de 1999. A área da antiga pedreira será recuperada topograficamente com a operação do Aterro Itaquera e deverá ser urbanizada, assim que se encerrarem as operações do aterro municipal.

-pedreira Itatinga, situada em Guarapiranga, Zona Sul do Município de São Paulo, que serviu como área de aterro de entulhos e inertes pela Prefeitura Municipal de São Paulo desde 1980 e teve sua recuperação topográfica concluída em 2004.

b) Reabilitação para aterro sanitário 
-pedreira Firpavi, localizada na divisa de Guarulhos com São Paulo, será aterrada com resíduos sólidos urbanos e foi ocupada anteriormente por mineração de quartzito para produção de areia para construção civil

-pedreira Firpavi, localizada em Santos

Os autores salientam para o uso temporário do solo que caracteriza os aterros, assim como ocorre na mineração, pois no encerramento das atividades um outro uso deverá suceder o aterro e um novo projeto de reabilitação será necessário.

c) Reabilitação para aterro de resíduos industriais

-aterro industrial Boa Hora, na região do ABC paulista, em funcionamento desde 1993, em um antigo porto de areia.

-pedreira Itaberaba, na Zona Norte de São Paulo, que funciona como aterro privado de resíduos industriais.

d) Reabilitação como "piscinão"

O problema freqüente de inundações em São Paulo levou os governos a apostar nas bacias de acumulação de cheias, vulgo "piscinões", como solução para o problema. A antiga Pedreira Lageado, na Zona Leste de São Paulo, começou as atividades minerárias em 1950 e as cessou em 2003. Hoje é utilizada pela Prefeitura Municipal de São Paulo para contenção de cheias do córrego Itaquera.

O porto de areia Caravelas, em Mogi das Cruzes tem a previsão futura para aproveitamento da cava como piscinão do Alto Tietê.

e) Reabilitação para urbanização (construção de edifícios comerciais ou residenciais).

• construção de um Hipermercado na pedreira Votorantim, na Zona Oeste do Município de São Paulo.

- construção de galpões comerciais e industriais nas antigas bacias de rejeitos argilosos remanescentes das atividades de extração de areia realizadas pela pedreira Sarpav, no Município de Barueri. 
f) Reabilitação como Reserva Florestal

-Pedreira Massaguaçu, em Caraguatatuba, ainda em operação: parte da área foi abrangida pela criação do Parque Estadual da Serra do Mar, em 1977.

g) Reabilitação em área rural

-Porto de areia Ponte Alta, zona rural de São Paulo: recuperação de taludes, redisposição de camada turfosa previamente removida e estocada e plantio de espécies nativas nos taludes e eucaliptos, nas áreas planas.

-portos de areia no Município de Araçariguama: recuperados com reflorestamento de espécies nativas, com fins agropecuários, fins agrícolas ou como "pesque-pagues".

h) Parques de uso público

-Parque Cidade de Toronto, na Zona Norte de São Paulo, antiga área de exploração de areia.

-Parque Francisco Rizzo, no Município de Embu das Artes, ex mineração de areia.

-Parque Ecológico Tietê, nos Municípios de São Paulo e Guarulhos, antiga área de exploração de areia.

Bittar (1997) estudou a recuperação de áreas degradadas pela mineração na Região Metropolitana de São Paulo e relatou que as antigas áreas de mineração hoje ocupadas por outros usos do solo compreendem duas situações distintas: áreas em que a ocupação ocorre de forma desordenada; e áreas em que se implementa um projeto planejado de uso do solo. A ocupação desordenada ocorre em $24 \%$ dos casos e se caracteriza pela ausência de um plano prévio, revelando modalidades de uso do solo cujas possibilidades de gerenciamento e sustentabilidade são extremamente incertas. Os tipos de uso atual do solo freqüentes nessas áreas são os depósitos de resíduos e as habitações de baixa renda. Os projetos de recuperação planejada compreendem $76 \%$ dos casos, sendo predominantes os de disposição de resíduos, seguidos pelos projetos de 
áreas de lazer, recreação, esportes comunitários, construções habitacionais e loteamentos.

Os projetos de recuperação de áreas degradadas para áreas de lazer, recreação e esportes comunitários revela modalidades de uso bastante favoráveis quanto à gerenciabilidade e à sustentabilidade local. A participação na recuperação dessas áreas é $100 \%$ do setor público, enquanto que o setor privado recupera as áreas visando habitações, loteamentos, indústrias e comércios. Ressalta-se o fato de que as empresas de mineração têm tido uma participação muito pequena $(5 \%)$ em relação ao total de projetos de reabilitação implementados (Bitar, 1997).

Esse autor cita as seguintes áreas verdes situadas na Região Metropolitana de São Paulo como antigas áreas de mineração reabilitadas: Lagos do Parque Ibirapuera, Parque Cidade de Toronto, Parque São Domingos, Parque Ecológico do Tietê e Parque Villlabos, sendo os três primeiros, responsabilidade da Prefeitura Municipal e os dois últimos, do Governo Estadual.

\subsection{Conservação e manutenção de áreas verdes}

A conservação e manutenção de todos elementos que compõem uma área verde pública devem merecer atenção continuada dos órgãos públicos que as gerenciam e da população que as utilizam. O uso público de uma área verde está intimamente ligado à manutenção, conservação e segurança que esta área recebe (Guzzo, 2003).

Todo elemento natural constituinte de uma área verde, principalmente a vegetação deve ser manejada constantemente, incluindo as seguintes técnicas de manejo: podas em galhos podres, secos ou lascados; extrações de árvores com risco de queda ou que apresentam algum problema fitossanitário irreparável; plantio de novas árvores, objetivando substituição das extraídas e/ou adensamento da vegetação de porte arbóreo; tratamento fitossanitário; roçada e coroamento. Com relação aos equipamentos de lazer e a todo mobiliário urbano que faz parte da área verde, deve-se reparar todo dano existente e paralelamente, desenvolver campanha educativa aos usuários para uso adequado e proteção dos mesmos. Um banco quebrado ou uma luminária que não 
funcione é motivo suficiente para reprodução desses e de outros tipos de danos. O que dá segurança em uma área verde na cidade é o seu uso constante pela população e uma guarda municipal que seja mais educativa que punitiva. Esse uso ocorrerá se a praça estiver dotada de iluminação eficiente, equipamentos funcionando, gramados capinados, árvores e copas altas e muitos outros itens relacionados à conservação e manutenção dos elementos existentes na área (Guzzo, 2003).

A manutenção do verde urbano é justificada atualmente pelo seu potencial em realçar aspectos associados à qualidade ambiental e interferir positivamente na qualidade de vida pela manutenção das funções ambientais, sociais e estéticas que venham mitigar ou amenizar a gama de propriedades negativas da urbanização (Oliveira, 1996).

Um plano de manutenção e conservação dos espaços públicos é essencial para o bom funcionamento destes espaços. De acordo com Silveira ${ }^{7}$ citado por Freire (2005), os parques, alvos de delitos praticados por delinqüentes, são espaços carentes de atividades e, por estarem degradados, conduzem a práticas anti-sociais que levam à sua própria autodestruição. Foram evidenciados indicadores de relação inversa entre variáveis de lazer (oferta de espaços livres públicos, sua manutenção e existência de programas socioculturais) e a violência urbana.

Apesar das importantes funções ambientais das áreas verdes urbanas, a população das cidades nem sempre está consciente a respeito da necessidade de um manejo adequado da mesma e, muitas vezes, não contribui para a sua manutenção. Aliado a isto, a falta de um planejamento adequado não permite aproveitar todas as vantagens e benefícios que as áreas verdes viárias proporcionam em uma cidade (Timo, 2001).

\section{8 Áreas degradadas urbanas e Áreas verdes}

É indiscutível a correlação existente entre a quantidade de verde de uma cidade e

\footnotetext{
7 SILVEIRA, S.V. A relação dos espaços livres públicos de lazer com a violência urbana: o caso do Distrito Federal. Brasília, 2000. 156p. Dissertação (Mestrado) - Faculdade de Arquitetura e Urbanismo, Universidade de Brasília.
} 
a qualidade de vida que essa cidade oferece a seus habitantes. O processo de urbanização desordenado que caracterizou o crescimento das cidades foi acompanhado, nas últimas décadas, por uma imprevidência quase sistemática dos setores público e privado, no que se refere à criação e principalmente à manutenção de áreas verdes associadas ao bemestar, à recreação e ao lazer. A necessidade de consumo do verde se intensifica a partir da consistência da busca de melhor nível de vida em termos de conforto urbano. O papel que o verde representa em um núcleo urbano não é apenas de mero agente despoluidor. $\mathrm{Na}$ verdade, os efeitos subjetivos gerados pela indisponibilidade do verde são mais importantes do que os efeitos diretos por ele gerados, quais sejam, redução das flutuações da temperatura do meio ambiente, eventual ação despoluidora e até mesmo aspecto paisagístico (Chaddad, 2000).

O verde, quando associado a equipamentos de recreação que estimulem o contato com a vegetação, assume um papel importantíssimo no aumento da qualidade de vida da população.

À medida que novas áreas verdes são oferecidas à população, desde os centros mais desenvolvidos até os mais periféricos, pode-se alterar decisivamente o tipo de vida e, conseqüentemente, a integração da comunidade. A existência do verde conduz a uma série de manifestações na comunidade, em termos artísticos, culturais, esportivos e recreativos. A proliferação dos espetáculos ao ar livre encontra nas áreas verdes o ambiente propício para sua implantação. Mas é o aspecto comunitário que é a resultante mais direta da disponibilidade de espaços livres transformados em áreas verdes, porque, sendo áreas naturais de convergência, exercem o papel de agente catalisador e motivador de congregação comunitária. $\mathrm{O}$ homem procura o verde porque se sente bem em meio à vegetação e, ao praticar esportes e ao desfrutar dessas áreas, ele realmente passa a receber seus benefícios. O importante é que, dentro da concepção de uma sociedade moderna, em que o efeito demonstração é um fato concreto, a necessidade do verde não é uma filosofia, mas um fator de sobrevivência urbana (Chaddad, 2000).

Portanto, a necessidade de cumprimento da legislação aliada à "urgência de espaços livres, de praças públicas, de 'squares', de jardins, de parques” (Franco, 2001), 
leva ao incentivo à transformação de áreas degradadas pela mineração em parques e áreas verdes, oferecendo aumento de qualidade de vida à população.

No Município de Curitiba, Estado do Paraná, a idéia de incremento da rede de parques públicos, a partir das preocupações ambientais, resultou em um bem estruturado esforço de planejamento de longo prazo, que teve como motivação inicial, a conservação dos remanescentes florestais e dos fundos de vales em seu papel no controle de enchentes e de outras áreas identificadas como ambientalmente sensíveis, como antigas jazidas de exploração mineral desativadas. No sentido de reforçar o caráter comunitário de tais espaços e assim envolver a população nas tarefas de conservação, em especial aquelas relacionadas à manutenção dos limites físicos, foram localizados nos parques, equipamentos públicos de fins culturais, ou construções de caráter simbólico, cujo sentido era servir de foco de atração para a comunidade. Em alguns casos, trata-se de grandes infra-estruturas, como o caso do Parque da Pedreira, em que se encontra a Ópera de Arame, um teatro com 2.600 lugares e um espaço para grandes eventos ao ar livre, que comporta cerca de 10 mil pessoas. Em outros casos, são construções de menor porte, como o centro de atividades artísticas do Parque São Lourenço ou a sede da Universidade Livre do Meio Ambiente (na verdade um centro de estudos de alternativas ambientais), no Bosque Zaninelli (Barcellos, 2005). Além desses, o Parque Tanguá, inaugurado em 1996, é considerado um dos mais belos parques da cidade, com paredões de pedras e cascatas e lagos e um túnel com aproximadamente 50 metros, escavado dentre as paredes rochosas. O Parque Ecológico Costa, inaugurado em 2000, foi construído em uma antiga pedreira de brita explorada até a década de 60.

No Estado de São Paulo algumas áreas verdes são conhecidas como locais outrora minerados:

- Parque Francisco Rizzo, Município de Itu, extração de areia;

- Parque Prefeito Luiz Roberto Jábali e Parque Dr. Luiz Carlos Raya, extração de basalto para brita, Município de Ribeirão Preto;

- Praça Dr. Ulisses Guimarães, extração de basalto para brita, Município de Campinas;

- Parque do Varvito, extração de varvito, Município de Itu; 
- Parque das Lavras e Parque da Rocha Mountoneé, extração de varvito, Município de Salto.

- Parque Cidade de Toronto, Parque Ecológico Tietê, Parque Ibirapuera e Parque Villa Lobos, extrações de areia, Município de São Paulo;

- Parque São Domingos, extração de basalto para brita, Município de São Paulo;

Tão importante quanto à criação de novas áreas verdes é a manutenção das áreas estabelecidas, através de programas de conservação e proteção. As áreas de preservação permanente, prioritariamente, deverão ser identificadas, demarcadas, protegidas por legislação específica e conservadas de modo adequado, a fim de preservar o patrimônio natural existente.

\subsection{Metodologia de análise: estudos de caso}

Dias (2001) relata várias discussões obtidas acerca dos estudos de caso. O estudo de caso enquadra-se no grupo de métodos de pesquisa denominados qualitativos, que se caracterizam por um foco maior na compreensão dos fatos do que na sua mensuração. $O$ estudo de casos tem sido empregado como método de pesquisa em numerosos campos do conhecimento, notadamente administração e políticas públicas e planejamento urbano e regional, tanto em aplicações práticas como em estudos acadêmicos. A principal característica do método é a realização de uma análise intensa de uma situação singular.

Yin (1994) acrescenta que o estudo de caso deve cobrir o fenômeno propriamente dito e o contexto no qual ele ocorre, sendo ideal para responder às perguntas "como" e "por quê". Na busca da compreensão do fenômeno, os limites entre este e o contexto nem sempre são claramente definidos. Assim, os fatos e seu contexto não se dissociam e as generalizações eventualmente resultantes da pesquisa devem considerar esta limitação. Um aspecto importante que permeia esta discussão diz respeito aos limites da generalização dos resultados obtidos em estudos de caso. Tendo em mente que os casos em estudo não constituem uma amostra no sentido estatístico, o objetivo do pesquisador deve ser o de formular, expandir ou generalizar teorias 
(generalização analítica) e não quantificar freqüências (generalização estatística). A necessidade de se proceder a uma análise profunda de cada caso limita, por razões de prazos e custos, o número de casos a ser estudados. A lógica, neste caso, é a da reprodução do fenômeno. O estudo de caso como método de pesquisa apresenta duas grandes variantes, o caso único e múltiplos casos. Um único caso pode ser adequado quando se tratar de um caso crítico capaz de confirmar ou refutar uma teoria bem elaborada. Também pode ser utilizado quando for um caso único, extremo ou revelador de determinado fenômeno. No estudo de casos múltiplos, cada caso estudado é completo em si e revela evidências que se acumulam em diferentes contextos. Deste modo, pode conduzir à reprodução literal, que ocorre quando cada caso apresenta as mesmas evidências, ou à reprodução teórica, quando os casos produzem evidências contrastantes, porém as diferenças podem ser satisfatoriamente explicadas.

O estudo de caso caracteriza-se pela análise em profundidade de um objeto ou um grupo de objetos, que podem ser indivíduos ou organizações. O pressuposto deste estudo é que, ao se conhecer muito bem como ocorre o fenômeno em um ou poucos indivíduos, pode-se levantar hipóteses sobre como o fenômeno acontece em geral. Por causa disto, o estudo de caso é bastante apropriado em pesquisas exploratórias e não apropriado para estudos explicativos, já que, neste caso, não se podem generalizar os resultados encontrados ( $\mathrm{Gil}^{8}$, citado por Acevedo \& Nohara, 2004).

\footnotetext{
${ }^{8}$ Gil, A. Como elaborar projetos de pesquisa . São Paulo: Atlas. 1996.
} 


\section{MATERIAIS E MÉTODOS}

O método de pesquisa utilizado foi o de estudo de casos, baseado nos casos múltiplos, já que se trata de uma pesquisa exploratória e descritiva de três locais que atualmente são áreas verdes e anteriormente foram minerações, que revelam evidências e se acumulam em diferentes contextos.

As áreas escolhidas para estudo foram o Parque Prefeito Luiz Roberto Jábali / Município de Ribeirão Preto / SP, o Parque do Varvito / Município de Itu / SP e a Praça Dr. Ulisses Guimarães / Município de Campinas / SP. Tais áreas concentram-se em atuais áreas verdes públicas, que foram mineradas para a extração de materiais aproveitados na construção civil e utilizaram o mesmo método de lavra - rocha para brita (em Ribeirão Preto e Campinas) e varvito (em Itu) - lavras em encosta, conduzidas a seco, desenvolvidas em maciços rochosos, em minas a céu aberto, por escavação mecânica com formação de bancadas, utilizando, quando necessário, o desmonte da rocha por explosivos.

\subsection{Parte teórica}

A parte teórica do trabalho consistiu no levantamento de dados bibliográficos sobre cada uma das áreas, a partir do levantamento dos seguintes aspectos básicos:

- Aspectos regionais da área de estudo

- História do Município

- Localização e acesso ao Município

- Aspectos físicos e populacionais do Município 
- Aspectos sociais e econômicos do Município

- Aspectos vegetacionais do Município

Esses aspectos foram levantados em pesquisas bibliográficas dirigidas à literatura disponível sobre os Municípios, em revistas, jornais e meios eletrônicos. Foram analisados documentos históricos locais e regionais, a fim de se conhecer a história da paisagem local e, conseqüentemente, sua evolução ao passar do tempo.

- Aspectos locais da área de estudo

- Características gerais da área verde

- Situação da área durante a atividade de extração do minério

- Legislações Municipais incidentes sobre a área

Envolveram três etapas de estudo:

a) Características gerais da área verde: pesquisas à bibliografia disponível nos diversos departamentos das Prefeituras Municipais locais, sobre as características da área verde estudada;

b) Situação da área durante a atividade de extração do minério, subdividida em:

- localização da área verde: medida com aparelho GPS, marca Magellan, através do sistema de projeção transversa de Mercátor (coordenadas UTM);

- plotagem da área no "overlay" (mapa do DNPM, em escala 1:50.000, baseado na folha cartográfica correspondente do IBGE, que possui todas as poligonais DNPM requeridas para extração mineral no Estado de São Paulo) e reconhecimento do número do processo DNPM, que engloba a área estudada;

- estudo do processo DNPM referente ao local: com o número do processo, é possível obter as informações básicas e o histórico do processo no programa de microcomputador, ambiente Windows, do mesmo departamento denominado "Cadastro Mineiro", que apresenta dados sobre todos os processos DNPM do país; caso o processo não exista mais, seja por indeferimento, desistência ou cancelamento do titular, é possível obter informações no programa de microcomputador para sistema operacional 
DOS, denominado "sicom", do mesmo departamento, do ano de 1999, que resume, em tópicos, o histórico dos processos DNPM.

c) Legislações Municipais incidentes sobre a área: pesquisas aos departamentos das Prefeituras Municipais locais, responsáveis pela legislação incidente sobre as áreas verdes e sobre as áreas degradadas do Município;

Os mapas ilustrativos foram organizados a partir de acervos cartográficos já existentes do Instituto de Pesquisas Tecnológicas - IPT, Instituto Geográfico e Cartográfico - IGC, Instituto Brasileiro de Geografia e Estatística - IBGE, Prefeitura Municipal de Ribeirão Preto e das representações de Tanno \& Sintoni (2003) e de Seitzer (1956).

\subsubsection{Parque Prefeito Luiz Roberto Jábali / Município de Ribeirão Preto / SP}

\subsubsection{Aspectos regionais da área de estudo}

\subsection{História do Município de Ribeirão Preto}

A Lei Provincial n ${ }^{\circ} 51$ de 02 de abril de 1870, criou o Distrito de Ribeirão Preto. O Município foi criado pela Lei Provincial $n^{\circ} 67$ de 12 de abril de 1871, com território desmembrado de São Simão, verificando-se a sua instalação a 04 de junho de 1874. Por força da Lei provincial no 34 de 07 de abril de 1879, passou a denominar-se Entre Rios, sendo porém restabelecido o nome anterior pela Lei nº. 99, de 30 de junho de 1881. Em 1885, foi criado o Distrito de Sertãozinho (elevado a Município em 1896) e, em 1893, o de Cravinhos, que obteve autonomia em 1897. A vila de Ribeirão Preto adquiriu foros de cidade por efeito da Lei Provincial $n^{\circ} 85$ ou 88 de $1^{\circ}$. de abril de 1880 . Há quem afirme que o Município de Ribeirão Preto teria sido criado em 06 de setembro de 1892. A 30 de novembro de 1938, quando se compunha dos Distritos de Ribeirão Preto e Bonfim, sofreu reestruturação administrativa, com a criação do Distrito de Guaiapara. 
Em 1953, Gaturama passou a denominar-se Bonfim Paulista. Pela Lei Estadual no 8092 de 28 de fevereiro de 1964, perdeu o distrito de Dumont, que foi elevado à categoria de Município e instalado em 1965. Atualmente está dividido em 3 Distritos: Ribeirão Preto, Bonfim Paulista e Guatapará (City Brazil, 2005a).

Ribeirão Preto era termo da Comarca de São Simão, quando o Decreto $n^{0} 7064$ de 31 de outubro de 1879, transferiu a sede da Comarca para seu termo, sendo instalado a 20 de dezembro de 1878. A Comarca de Ribeirão Preto, criada pela Lei n ${ }^{\circ} .80$ de 25 de agosto de 1892, foi instalada em 10 de outubro seguinte. O nome Ribeirão Preto deve-se aos rios que correm na cidade. A primeira Matriz de Ribeirão Preto que existiu na atual Praça XV de Novembro localiza-se onde, hoje, está a Fonte Luminosa (City Brazil, 2005a).

\subsection{Localização e acesso ao Município de Ribeirão Preto}

Ribeirão Preto situa-se no Nordeste do Estado de São Paulo (Anexo A), nas coordenadas $21^{\circ} 10^{\prime} 42^{\prime \prime}$ Sul e 47\%48'24" Oeste, a $313 \mathrm{~km}$ da capital. Os limites da cidade são dados pelos seguintes Municípios: ao sul, Guatapará; a sudeste, Cravinhos; ao norte, Jardinópolis; a leste, Serrana; ao oeste, Dumont; a noroeste, Sertãozinho; e ao nordeste, Brodósqui (Prefeitura Municipal de Ribeirão Preto, 2005).

A principal via de acesso ao Município é através da Via Anhanguera (SP 330), uma rodovia de pista dupla, que o liga à capital do Estado, à Campinas e ao Triângulo Mineiro. Além desta rodovia, o Município conta, ainda, com mais um conjunto de 5 rodovias que possibilita acesso fácil para diferentes regiões do Estado e do País. O Município de Ribeirão Preto ainda tem a característica de situar-se no caminho que liga a Grande São Paulo à região central do país, com destaque para Brasília, da qual dista $706 \mathrm{Km}$. Localiza-se relativamente próximo dos principais pólos econômicos do interior de São Paulo (Bauru, Campinas, São José do Rio Preto, entre outros) e do Triângulo Mineiro (Prefeitura Municipal de Ribeirão Preto, 2005). 


\subsection{Aspectos físicos e populacionais do Município}

O Município de Ribeirão Preto perfaz uma área de $651 \mathrm{~km}^{2}$, sendo $274,08 \mathrm{Km}^{2}$ de área urbana e 376,92 $\mathrm{Km}^{2}$ de área rural (Prefeitura Municipal de Ribeirão Preto, 2005).

O Município de Ribeirão Preto, (Instituto de Pesquisas Tecnológicas - IPT, 1981b) localiza-se, geomorfologicamente, nas Cuestas Basálticas (Anexo B), que apresenta um relevo escarpado nos limites com a Depressão Periférica (a leste), seguido de uma sucessão de grandes plataformas estruturais de relevo suavizado, inclinadas para o interior em direção à calha do Rio Paraná.

Ross \& Moroz (1997) denominam a unidade morfoescultural do Município de Ribeirão Preto como Patamares Estruturais de Ribeirão Preto, cujas formas de relevo denudacionais, constituem-se por colinas amplas e baixas com topos tabulares, tendo os vales entalhamento médio com menos de 20 metros e as dimensões interfluviais entre 750 até mais de 3.750 metros. As altimetrias variam entre 500 e 700 metros e as vertentes apresentam declividades médias entre 2 e $10 \%$.

Geologicamente (IPT, 1981a), Ribeirão Preto encontra-se na Formação Serra Geral, pertencente ao Grupo São Bento, da Bacia do Paraná (Anexo C). As eruptivas da Serra Geral compreendem um conjunto de derrames de basaltos toleíticos de coloração cinza a negra, textura afanítica entre os quais se intercalam arenitos finos a médios. Segundo descrição do Mapa Geológico do Estado de São Paulo (IPT, 1981a), os arenitos da Formação Botucatu interdigitam-se, em grande escala, com derrames da Formação Serra Geral, tornando complexa a delimitação de ambas, em âmbito regional.

A litologia da unidade morfoescultural do Município de Ribeirão Preto é basicamente constituída por basaltos e os solos são do tipo Latossolo Roxo, nos setores mais aplainados e Terra Roxa Estruturada nas vertentes mais inclinadas. Os principais rios que drenam esta unidade são os Rios Mogi-Guaçu, Pardo e Ribeirão Preto (Ross \& Moroz, 1997). 
Essas características estão associadas a lavra de basalto, conforme citado por Tanno \& Sintoni (2003), e explica a grande quantidade de exploração deste minério no Município de Ribeirão Preto.

O clima da região, segundo a classificação de Köeppen (Setzer, 1956), é do tipo Cwa (Anexo D) denominado quente, mesotérmico de inverno seco, com verões quentes e estação chuvosa no verão. A temperatura média do mês mais frio é inferior a $18{ }^{\circ} \mathrm{C}$, enquanto a do mês mais quente ultrapassa os $22^{\circ} \mathrm{C}$. $\mathrm{O}$ índice pluviométrico varia entre $1.100 \mathrm{~mm}$ e $1.700 \mathrm{~mm}$. A estação seca ocorre entre os meses de abril e setembro, enquanto a chuvosa; entre janeiro e fevereiro.

A precipitação pluviométrica média anual é $1.426,80 \mathrm{~mm}$ de chuva e a umidade relativa do ar anual é 71\% (Prefeitura Municipal de Ribeirão Preto, 2005).

Com 504.923 habitantes segundo o Censo Demográfico do IBGE de 2.000 (IBGE, 2005), o Município de Ribeirão Preto encontra-se entre os maiores do Estado de São Paulo e do Brasil. Ribeirão Preto apresentou um intenso crescimento populacional durante as décadas de setenta e oitenta. A taxa média de crescimento populacional reduziu-se significativamente entre 1991 e 1996, ficando abaixo da taxa média de crescimento do Estado. Pelo Censo do IBGE de 2.000, 99,5 \% da população reside em área urbana e 0,5\% reside em área rural, distribuída em aproximadamente $50 \%$ de homens e 50\% de mulheres (Prefeitura Municipal de Ribeirão Preto, 2005).

\subsection{Aspectos sociais e econômicos do Município}

O Município de Ribeirão Preto possui no ano de 2002, um Produto Interno Bruto - PIB per capita em torno de R \$ 7.700,00 (Instituto Brasileiro de Geografia e Estatística - IBGE, 2005) e se constitui no pólo de atração das atividades comerciais e de prestação de serviços, cuja área de influência extrapola os limites da própria região de governo, estendendo-se para as regiões de Franca, Barretos, São Carlos, São João da Boa Vista e outras do próprio Estado de São Paulo e de outros estados (Prefeitura Municipal de Ribeirão Preto, 2005). 
Em relação à indústria deve-se destacar, em primeiro lugar, a força da agroindústria, que está muito relacionada ao desempenho do setor primário. $\mathrm{O}$ Município de Ribeirão Preto e região são os maiores produtores mundiais de açúcar e álcool. As usinas representam uma das principais atividades econômicas da região, o que acaba estimulando o desenvolvimento de outros setores, como por exemplo, o de máquinas agrícolas e equipamentos para usinas. Outras indústrias também de destaque na região são as de suco de laranja, beneficiadoras de café, soja, amendoim, manga, limão, abóbora, indústrias alimentícias, indústrias de ração, fertilizantes, entre outras: há um amplo complexo agro-industrial na região. Além da agroindústria, Ribeirão Preto destaca-se pela indústria de equipamentos médicos-odontológicos e farmacêuticos (Prefeitura Municipal de Ribeirão Preto, 2005).

A indústria mineral representou $5 \%$ dos estabelecimentos industriais do Município de Ribeirão Preto em 2001, empregando 464 empregados diretos, num salário médio de 3,5 salários mínimos por empregado (Prefeitura Municipal de Ribeirão Preto, 2005).

\subsection{Aspectos vegetacionais do Município}

A região de Ribeirão Preto situa-se em área de transição entre Floresta Estacional Semidecidual e formações savânicas, sendo esta transição na forma de encraves (IBGE, 1993). A formação savânica corresponde ao Cerradão, que ocorre em aproximadamente um quarto da área do Município, predominantemente na região nordeste. A Floresta Estacional Semidecidual, ou Floresta Mesófila, predomina no restante do Município (Kotchetkoff-Henriques, 2003).

Oliveira Filho \& Fontes $^{9}$ citado por Kotchetkoff-Henriques (2003) destaca que a flora das matas semidecíduas do interior do Estado representa uma fração da flora das matas pluviais Atlânticas, compostas por espécies que apresentam tolerância aos períodos de seca que são tão mais longos quanto mais distantes do litoral. Esta

\footnotetext{
${ }^{9}$ OLIVEIRA FILHO, A.T., FONTES, M.A.L. Patterns of floristics differenciation among Atlantic Forests
} in Southeastern Brazil and the influence and climate. Bitropica, v. 32, p.793-810, 2000. 
sazonalidade na disponibilidade hídrica determina a menor diversidade de espécies nesta formação. Estas matas apresentam estrutura mais simples que as florestas pluviais.

A Floresta Estacional Semidecídua forma uma transição em composição de espécies entre a floresta pluvial tropical e o cerradão. O padrão de distribuição desses tipos de vegetação numa mesma região está relacionado ao tipo de rocha e à posição topográfica. Dentre as espécies que vicejam nas florestas semidecíduas encontram-se o pau-d'alho, o guatambu, o cedro, o jatobá, o jequitibá rosa, o pau-jangada, o capixingui, dentre outras. Nas matas ciliares são comuns o pau-espinho, o jenipapo, o ingá, o copaíba, o açoita-cavalo, a embira-sapo, o cedro-rosa, dentre várias outras espécies (Secretaria do Meio Ambiente - SMA, 2000).

A Floresta Estacional Semidecidual, caracterizada no Ministério de Minas e Energia - MME (1983), está presa à dupla estacionalidade climática, uma chuvosa seguida por estiagem e outra subtropical sem período seco, mas com secas fisiológicas provocadas pelo frio, com temperaturas abaixo ou próximas a $15^{\circ} \mathrm{C}$. Estes fatores condicionam uma estacionalidade foliar dos elementos arbóreos dominantes, que têm adaptação fisiológica à deficiência hídrica ou à baixa temperatura, durante certo tempo. As Florestas Estacionais Semideciduais estão em ambientes sobre litologia variada, com mais de 60 dias secos. A porcentagem de espécies arbóreas caducifólias em relação ao número total de árvores nos agrupamentos remanescentes situa-se entre 20 e $50 \%$ durante a época desfavorável.

A Savana (Cerrado) caracteriza-se pelas várias formações campestres nas áreas tropicais e subtropicais da Zona Neotropical intercaladas por plantas lenhosas arbóreas, de pequeno a médio porte, em geral serpenteadas por florestas-de-galeria. Ocupa uma área onde domina atualmente a fisionomia gramíneo-lenhosa, geralmente mantida pelo fogo, e pequenos agrupamentos dispersos nas formações arbóreas (MME, 1983).

O cerradão é uma formação florestal com aspectos xeromórficos. Caracteriza-se pela presença de espécies que ocorrem no cerrado sentido restrito e também de espécies de mata. Possui fisionomia florestal, mas similaridade florística maior com o cerrado. Apresenta dossel predominantemente contínuo e cobertura arbórea que pode oscilar de $50 \%$ a $90 \%$. A altura média do estrato arbóreo varia de 8 a 15 metros, proporcionando 
condições de luminosidade que favorecem a formação de estratos arbustivos e herbáceos diferenciados. Embora a formação seja perenifólia, algumas espécies podem apresentar deciduidade foliar acentuada. A presença de epífitas é reduzida. Oliveira Filho \& Ratter $^{10}$ citado por Kotchetkoff-Henriques (2003) relatam que as famílias mais importantes no cerrado em termos de número de espécies são Leguminosae, Malpighiaceae, Myrtaceae, Melastomataceae e Rubiaceae, embora muitas áreas apresentem vegetação dominada por Vochysiaceae.

\subsubsection{Parque do Varvito / Município de Itu / SP}

\subsubsection{Aspectos regionais da área de estudo}

\subsection{História do Município de Itu}

A palavra Itu tem origem Indígena (UTUGUAÇU = Cachoeira Grande). Itu foi a mais rica e populosa Vila da Capitania da São Paulo e o "Centro de Liberalismo Paulista". Foi elevada à Vila em 18 de abril de 1657, à Comarca em 02 de Dezembro de 1811 e recebeu a categoria de Cidade em 05 de fevereiro de 1842. Em 18 de Abril de 1873, realizou-se em Itu, a famosa "Convenção Republicana", que congregou os adeptos da forma republicana de governo, a fim de iniciarem a propaganda do novo regime. Daí a cidade de Itu ser cognominada "Berço da República". Em 19 de Setembro de 1978, foi instalada a Junta de Conciliação e Julgamento pela Justiça do Trabalho e em 29 de Setembro de 1979, a cidade de Itu foi transformada em Estância Turística (City Brazil, 2005b).

As famosas lajes da pedreira de Itu são historicamente conhecidas e utilizadas para construção e pavimentação de edifícios e calçadas das principais ruas da cidade de Itu desde, pelo menos, o início do século XVIII. José Bonifácio de Andrade e Silva e seu

\footnotetext{
${ }^{10}$ OLIVEIRA FILHO, A.T.; RATTER, J. Vegetations physiognomies and woody flora of the cerrado biome. In: The cerrados of Brazil. Ecology and natural history of a Neotropical savanna. Oliveira, P.S. \& Marquis, R.J. Columbia University Press, p.91-120, 2002.
} 
irmão Martim Francisco Ribeiro de Andrade referem-se a rochas sedimentares correspondentes ao varvito no relatório de sua "Viagem Mineralógica na Província de São Paulo", realizada em 1820. Outros pesquisadores que percorreram a região de Itu, no final do século XIX e princípios do século XX, fizeram também referências a esta rocha. O pintor ituano Miguelzinho Dutra deixou um registro visual da "Pedreira de Itu", em significativa aquarela datada de 1841 (Mendes, 1944).

O reconhecimento da laje de Itu como varvito, em 1938, deve-se inicialmente a Othon H. Leonardos, geólogo do então Serviço de Fomento da Produção Mineral do Brasil. Embora outras ocorrências de rochas similares já fossem conhecidas no Sul do Brasil (Leinz, 1937), Leonardos considerou a pedreira de Itu como "a mais linda exposição de varvito encontrada no país". O local tornou-se desde então geologicamente famoso e vem sendo, freqüentemente visitado por numerosos geólogos, cientistas, professores universitários, estudantes de geologia do Brasil e exterior interessados em examinar essa excepcional e rara exposição de rochas tão peculiares.

\subsection{Localização e acesso ao Município de Itu}

Itu situa-se na região Centro-Leste do Estado de São Paulo (Anexo A), nas coordenadas $23^{\circ} 16^{\prime} \mathrm{Sul}$ e $47^{\circ} 18^{\prime}$ Oeste, a $92 \mathrm{~km}$ da capital. Os limites da cidade são dados pelos seguintes Municípios: Salto, Elias Fausto, Porto Feliz, Sorocaba, Mairinque, Araçariguama, Cabreúva, Itupeva, São Roque e Indaiatuba (O Melhor de Itu, 2005).

As principais vias de acesso ao Município de Itu são: SP 330 - Anhangüera e SP 348 - Bandeirantes (interliga Itu a São Paulo e Campinas), SP 280 - Castelo Branco (interliga Itu a São Paulo diretamente), SP 75 - Rodovia Santos Dumont (interliga Itu a Sorocaba e Campinas diretamente), SP 308 - Rodovia do Açúcar (interliga Itu diretamente a Piracicaba) e SP 79 - Waldomiro Camargo (permite acesso a Castelo Branco e Sorocaba) (O Melhor de Itu, 2005). 


\subsection{Aspectos físicos e populacionais do Município}

O Município de Itu perfaz uma área de $640 \mathrm{~km}^{2}$, segundo o Censo Demográfico do IBGE de 2.000 (IBGE, 2005), sendo que $78 \mathrm{~km}^{2}$ pertencem a área urbana, enquanto que $562 \mathrm{~km}^{2}$ à área rural.

O Município de Itu (IPT, 1981b) localiza-se, geomorfologicamente, na Zona do Médio Tietê, na Depressão Periférica (Anexo B), constituída principalmente por sedimentos com áreas expressivas de intrusões de rochas básicas com reflexos na sua topografia.

Ross \& Moroz (1997) denominam a unidade morfoescultural do Município de Itu como Depressão do Médio Tietê, cujas formas de relevo denudacionais, constituemse por colinas de topos amplos tabulares, tendo os vales entalhamento médio até 20 metros e as dimensões interfluviais entre 750 a 3.750 metros. As altimetrias variam entre 500 e 650 metros e as vertentes apresentam declividades médias entre 5 e 10\%.

Geologicamente (IPT, 1981a), Itu encontra-se na Formação Itararé, pertencente ao Grupo Tubarão, da Bacia do Paraná (Anexo C). Segundo descrição do Mapa Geológico do Estado de São Paulo (IPT, 1981), a Formação Itararé caracteriza-se por depósitos glaciais continentais, glácio-marinhos, fluviais, deltaicos, lacustres e marinhos, compreendendo principalmente arenitos de granulação variada, siltitos e folhelhos.

A litologia da unidade morfoescultural do Município de Itu é basicamente constituída por diabásios e arenitos e os solos são do tipo Latossolo Vermelho-amarelo, Latossolo Vermelho-escuro e Latossolo Roxo. Os principais rios que drenam esta unidade são os Rios Tietê, Piracicaba e Sorocaba (Ross \& Moroz, 1997).

Essas características aparecem nos arquivos históricos do Município de Itu, que se apresenta como uma das mais antigas glaciações do mundo. Visitando o local, observa-se a alternância de leitos claros e escuros; a rocha clara corresponde a sedimentação de "verão" (que não chegava a ser quente, mas cuja temperatura atingia temperaturas próximas a zero, possibilitando a fusão do gelo e sua conseqüente mudança 
de estado) e as camadas escuras a de "inverno". A glaciação ocorrida na região durou cerca de um milhão de anos e terminou a aproximadamente 120 séculos (Itu, 1962).

O clima da região, segundo a classificação de Köeppen (Setzer, 1956), é do tipo Cwa (Anexo D), com inverno seco, verões quentes e estação chuvosa no verão.

O regime pluviométrico é tropical típico, com um período chuvoso, iniciando em outubro e findando em abril e um período de estiagem, de maio a setembro, variando localmente o início e o término de cada um dos períodos. Os índices de precipitação situam-se entre 1.200 e $1.800 \mathrm{~mm}$ anuais (Companhia de Tecnologia e Saneamento Ambiental - CETESB, 2003).

Com 135.366 habitantes segundo o Censo Demográfico do IBGE de 2.000 (IBGE, 2005), sendo 123.942 pessoas (91,5\%) residentes na área urbana e 11.424 pessoas $(8,5 \%)$ residentes na área rural, distribuída em aproximadamente $50 \%$ de homens e $50 \%$ de mulheres.

\subsection{Aspectos sociais e econômicos do Município}

O Município de Itu possui no ano de 2002, um PIB per capita em torno de R\$ 10.000,00 e a economia baseada na agricultura (distribuída em cana-de-açúcar, feijão, milho e tomate, como culturas temporárias e abacate, café, Citrus, manga, maracujá e uva, como culturas permanentes), pecuária, indústrias extrativas, de transformação e construção, comércio e turismo, de acordo com os dados da Produção Agrícola Municipal de 2002 (IBGE, 2005).

Não foram encontrados dados sobre a porcentagem da indústria mineral no Município de Itu.

\subsection{Aspectos vegetacionais do Município}

O Município de Itu situa-se em área de transição entre Floresta Ombrófila e a Savana (Cerrado) (IBGE, 1993). 
A Floresta Ombrófila Densa, também designada de Floresta Pluvial (MME, 1983), ou simplesmente Mata Atlântica, como é mais popularmente conhecida, ocupa a área tropical mais úmida, com período seco anual, variando de 0 a 60 dias e se caracteriza pela presença de fanerófitas perenifoliadas, com brotos foliares geralmente desprovidos de proteção contra seca.

O termo Floresta Tropical Atlântica destaca a presença, nesta cobertura vegetal, de epífitas (bromeliáceas, orquidáceas) e de árvores de folhas sempre verdes (perenifólias). As palmeiras, como o palmito-doce, o tucum e a brejaúva, emprestam às florestas tropicais a sua físionomia mais típica. Entretanto, quando se analisa a biodiversidade da Floresta Atlântica, os dados mais surpreendentes são o grande número de espécies de Myrtaceae e a quantidade de fungos associados à rizosfera (SMA, 2000).

A Pedreira de Varvitos é um espaço territorial especialmente protegido, caracterizado por Área Natural Tombada (SMA, 2000). O tombamento constitui instrumento jurídico de proteção ao patrimônio cultural e natural, implicando restrições de uso que garantam a proteção e manutenção de suas características históricas, arqueológicas, turísticas, científicas e/ou paisagísticas.

\subsubsection{Praça Dr. Ulisses Guimarães / Município de Campinas / SP}

\subsubsection{Aspectos regionais da área de estudo}

\subsection{História do Município de Campinas}

A data oficial da fundação da cidade de Campinas deu-se, pela Câmara Municipal, em 14 de julho de 1774.

Em 1739, Barreto Leme chegou a Campinas com sua gente, vindos de Taubaté. Formou-se o bairro rural e seus habitantes obtiveram autorização para construir uma Igreja, em 1773. Em 27 de maio de 1774, Dom Luiz Antônio, o Morgado de Mateus, ordenou a fundação da povoação, nomeando Francisco Barreto Leme seus fundador, diretor e administrador. E, em 14 de julho de 1774, Frei Antônio de Pádua, primeiro 
vigário de Campinas, rezou na capela provisória a missa que assinalou a instalação da freguesia de Nossa Senhora da Conceição, a nova paróquia, até então subordinada à Paróquia de Jundiaí. Em 1775, Campinas chega à qualidade de Distrito, com o nome de Distrito de Conceição de Campinas, e em 1797 atinge a condição de Vila (Vila de São Carlos), sendo desmembrada de Jundiaí. Os habitantes eram 2.107 e moravam em pouco mais de 400 casas. Mas o nome de São Carlos, que nunca chegou a ser aceito pela população local, deixou de existir quando, em 1847, a vila foi elevada à categoria de Cidade. Surgia, então, oficialmente, Campinas (City Brazil, 2005c).

\subsection{Localização e acesso ao Município de Campinas}

Campinas situa-se na região Centro Leste do Estado de São Paulo (Anexo A),

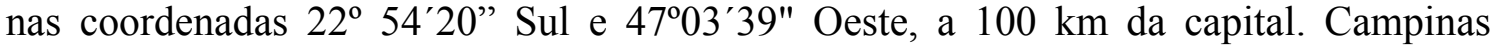
limita-se com os seguintes Municípios: Jaguariúna, Pedreira, Morungaba, Valinhos, Itupeva, Indaiatuba, Monte-Mor, Sumaré e Paulínia (City Brazil, 2005c).

$\mathrm{O}$ acesso à cidade de Campinas pode ser feito através das Rodovias Anhanguera (SP-330) e Bandeirantes (SP-348), que ligam Campinas e região à cidade de São Paulo; Rodovia Santos Dumont (SP-77), que leva à Sorocaba e também se entronca com a Rodovia Castelo Branco, interligando Campinas com o Oeste do Estado, Curitiba (PR) e com o Norte e Oeste do Paraná, Mato Grosso do Sul, Paraguai e Bolívia; Rodovia D. Pedro I (SP-65), que se entronca com a via Dutra no Município de Jacareí, ligando Campinas ao Rio de Janeiro; e a Rodovia Campinas-Mogi Mirim (SP - 340), fazendo a conexão com o Sul de Minas Gerais (City Brazil, 2005c).

\subsection{Aspectos físicos e populacionais do Município}

O Município de Campinas perfaz uma área de $887 \mathrm{~km}^{2}$, segundo o Censo Demográfico do IBGE de 2.000 (Prefeitura Municipal de Campinas, 2005), sendo que $417 \mathrm{~km}^{2}$ pertencem à área urbana e $470 \mathrm{~km}^{2}$ à área rural. 
O Município de Campinas (IPT, 1981b) localiza-se, geomorfologicamente, na Zona do Médio Tietê, na Depressão Periférica (Anexo B), constituída principalmente por sedimentos com áreas expressivas de intrusões de rochas básicas com reflexos na sua topografia.

Ross \& Moroz (1997) denominam a unidade morfoescultural do Município de Campinas como Depressão de Mogi-Guaçu, cujas formas de relevo denudacionais, constituem-se por colinas de topos amplos tabulares, tendo os vales entalhamento médio até 20 metros e as dimensões interfluviais entre 1.750 a 3.750 metros. As altimetrias variam entre 500 e 650 metros e as vertentes apresentam declividades médias entre 5 e $10 \%$.

Geologicamente (IPT, 1981a), Campinas encontra-se numa região de transição entre o Complexo Amparo do Pré-Cambriano e as Intrusivas Básicas Tabulares da Bacia do Paraná (Anexo C). Segundo descrição do Mapa Geológico do Estado de São Paulo (IPT, 1981), estas unidades litoestratigráficas caracterizam-se por biotita gnaisses, gnaisses migmatizados e diques básicos em geral, incluindo diabásios e soleiras diabásicas.

Campinas, com seus aspectos geológicos, engloba um dos grandes pólos produtores de brita no Estado de São Paulo (Tanno \& Sintoni, 2003).

A litologia da unidade morfoescultural do Município de Campinas é basicamente constituída por arenitos finos, arcóseos, argilito, siltitos, calcários e folhelhos e os solos são do tipo Latossolo Vermelho-amarelo, Latossolo Vermelho-escuro e Podzólico Vermelho-amarelo. Os principais rios que drenam esta unidade são os Rios Mogi-Guaçu e Pardo (Ross \& Moroz, 1997).

O clima da região, segundo a classificação de Köeppen, é do tipo Cwa (Anexo D) com uma estação quente e chuvosa de outubro a março, de temperatura média entre $22^{\circ}$ e $24^{\circ} \mathrm{C}$ e precipitação de $1.057 \mathrm{~mm}$ e uma estação seca de abril a setembro, de temperatura média entre $18^{\circ} \mathrm{C}$ e $22^{\circ} \mathrm{C}$ e precipitação de $325 \mathrm{~mm}$. (Ortolano et al, 1995).

A umidade relativa do ar média nos meses de outubro a março é $77 \%$ e nos meses de abril a setembro é de 65\% (City Brazil, 2005). 
Possui 969.596 habitantes, distribuídos em aproximadamente 50\% de homens e $50 \%$ de mulheres, segundo o Censo Demográfico do IBGE de 2.000 (Prefeitura Municipal de Campinas, 2005), sendo 953.218 pessoas (98,3\%) residentes na área urbana e 16.178 pessoas $(1,7 \%)$ residentes na área rural. O Município possui uma densidade demográfica de $1.118,83 \mathrm{hab} / \mathrm{km}^{2}$.

\subsection{Aspectos sociais e econômicos do Município}

Campinas é uma cidade de fortes expressões sócio-culturais, fluxos incessantes e circulação permanente. A cidade, propriamente "urbana", é adensada (construtiva e demograficamente), caracterizada como espaço de circulação e mobilidade (inclusive da população da região metropolitana), vivência coletiva e sociabilidades (Prefeitura Municipal de Campinas, 2005).

Economicamente, Campinas é marcada pela estruturação de um pólo de alta tecnologia, caracterizado pelas universidades, por uma rede complexa de comércio e serviços e por uma população migrante, demandada pelo pujante crescimento econômico dos anos 70, que permitiu à cidade enriquecer e desenvolver-se. Marcada por alto desenvolvimento econômico e humano, Campinas é uma cidade de diversidades e diferenças, de onde se projeta um mosaico de expressões, manifestações e tradições, que a torna uma cidade intensa, moderna e cosmopolita (Prefeitura Municipal de Campinas, 2005).

Conforme o Perfil Municipal da Fundação Sistema Estadual de Análise de Dados (SEADE), de 2001, apresentado pela Prefeitura Municipal de Campinas (2005), Campinas possui 2.653 estabelecimentos industriais, 8.505 estabelecimentos comerciais, 9.363 estabelecimentos ligados a serviços e 315 caracterizados como outros.

Não foram encontrados dados sobre a porcentagem da indústria mineral no Município de Campinas. 


\subsection{Aspectos vegetacionais do Município}

O Município de Campinas, assim como o Município de Itu, situa-se em área de transição entre a Floresta Ombrófila e a Savana (Cerrado) (IBGE, 1993).

Atualmente, Campinas encontra-se com sua cobertura vegetal nativa reduzida a 2.033,6 ha, o equivalente a 2,55\% da área total do Município. Aproximadamente 95\% dessa vegetação são formados por fragmentos da Floresta Estacional Semidecidual isolados, distanciados e submetidos a um grande número de fatores de perturbação, dentre os quais se destacam as invasões por gado, incêndios, extração seletiva, deposição de lixo e entulho. Os bosques naturais urbanizados da cidade de Campinas são resquícios da vegetação natural da região, dotados de infra-estrutura, transformados em áreas de lazer e abertos à visitação pública. As áreas de vegetação remanescente existente dentro dos parques e bosques municipais somam 38,01 ha e representam $1,87 \%$ da cobertura vegetal remanescente do Município, incluindo áreas que variam de 0,86 a 4,38 ha. Nessas áreas, foram encontrados $57,7 \%$ do total de espécies arbóreas registradas em Campinas até 1999, o que demonstra sua importância como testemunhos da flora arbórea da região e, conseqüentemente, a importância de sua conservação e o potencial educativo de fragmentos urbanizados. O aproveitamento desses fragmentos como bosques públicos minimiza a ação de alguns fatores de perturbação, tais como incêndios, extração seletiva e invasão pelo gado. Por outro lado, são áreas pequenas, com acentuado isolamento devido à urbanização do entorno e alvos de medidas de manejo inadequadas, como a introdução de espécies exóticas e nativas de outras regiões (Santin, 1999).

O Bosque dos Jequitibás é uma área natural tombada, localizada na parte central do Município de Campinas, considerada um monumento natural paisagístico do Estado, com remanescentes de vegetação original mesclados às espécies introduzidas, 0 zoológico, o museu histórico e áreas de lazer (SMA, 2000).

Estudos realizados por diversos pesquisadores nos bosques localizados em Campinas, descrevem a Floresta Estacional Semidecidual, como a vegetação de Mata 
Atlântica original do Município. Os estudos também podem indicar que, provavelmente, no passado, a vegetação de Campinas era constituída por cobertura vegetal contínua e que hoje se apresenta fragmentada, com remanescentes florestais entremeados por áreas urbanas e rurais, cujo processo de fragmentação pode estar influenciando para que os remanescentes se tornem cada vez mais distintos entre si (Santos \& Kinoshita, 2003).

No Bosque dos Alemães, localizado a aproximadamente 1.000 metros da Praça Dr. Ulisses Guimarães, conforme observado por Cielo Filho \& Santin (2002) em seu levantamento florístico, há espécies vegetais arbóreas nativas de outras regiões, nativas do próprio Município e indivíduos adultos de espécies exóticas, como Mangifera indica L. (mangueira).

\subsection{Parte prática}

A parte prática do trabalho consistiu no levantamento de dados a campo, sobre a situação atual de cada uma das áreas verdes estudadas. Para tanto, foram feitas visitas técnicas para coleta dos dados primários, através da comunicação e da observação.

O método de comunicação foi realizado com os respectivos responsáveis pela área, funcionários públicos ou terceirizados que, diariamente, estão presentes no local. A técnica de condução ao método de comunicação foi a entrevista informal, semelhante a uma conversa com o entrevistado; as perguntas foram feitas oralmente ao entrevistado, com o intuito de coletar dados sobre a área investigada.

$\mathrm{Na}$ análise técnica e observação direta sistemática, foi avaliado o estado de conservação das benfeitorias existentes na área verde, utilizando-se conceitos de 0 (zero) a 5 (cinco), onde foi considerado:

0 = não existe (quando a benfeitoria não existe)

1 = não funciona (quando a benfeitoria existe, mas não se encontra em uso, por falta de manutenção)

2 = péssimo (quando a benfeitoria encontra-se quebrada ou apresenta defeitos, que impedem seu uso pleno) 
3 = regular (quando a benfeitoria pode ser utilizada, apesar de defeitos ou falta de manutenção)

4 = bom (quando a benfeitoria está em boas condições de uso, apesar de antigas ou mal conservadas)

5 = ótimo (quando a benfeitoria encontra-se em plenas condições de uso e bem conservada)

Também foram analisadas, na observação direta sistemática realizada nas áreas de pesquisa, as medidas adotadas na estabilização dos processos de degradação outrora provocados pela atividade minerária.

A divulgação da área verde pelas respectivas Prefeituras foi avaliada, levando-se em consideração as placas de acesso ao local, distribuídas pelo Município, os folders de divulgação do local como um ponto turístico da cidade e outras maneiras de difusão da área como um ponto de atração municipal.

Após todas as informações coletadas, foram feitas a integração e a análise dos resultados obtidos e delineadas as conclusões sobre as áreas estudadas, além da delimitação de semelhanças, diferenças e demais generalizações para as verificações finais. 


\section{RESULTADOS E DISCUSSÕES}

\subsection{Parque Luiz Roberto Jábali / Município de Ribeirão Preto / SP}

\subsubsection{Aspectos locais da área de estudo}

\subsubsection{Características gerais do Parque Prefeito Luiz Roberto Jábali}

O Parque Prefeito Luiz Roberto Jábali localiza-se na região Centro-Leste do Município de Ribeirão Preto, nas coordenadas UTM 210.029 m E e 7.653 .537 m N ou

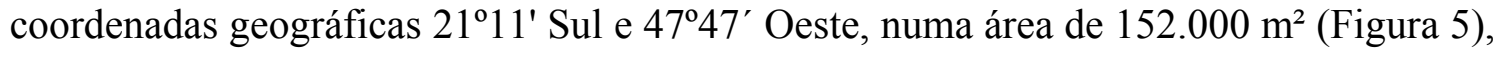
em uma área de antiga exploração de basalto. Localmente, principalmente nas bordas da pedreira, é possível observar aspectos da formação do solo litólico, derivado do basalto; o basalto ocorre na área, no nível mais baixo, como rocha-matriz, seguida dos matacões, amarelados por ação do intemperismo e, sobre este, a fina camada de solo litólico, cuja espessura máxima é de 30 centímetros de profundidade; por isso, armazena pouca água, sendo poucas as espécies de árvores que se adaptam a estas condições. É inteiramente formado, portanto, por vegetação de floresta tropical classificada como Mata Decídua, que tem como principal característica a perda total das folhas durante o inverno. Devido ao afloramento de rochas no solo, que impedem o surgimento de vegetação rasteira, a área possui aparência de bosque (Prefeitura Municipal de Ribeirão Preto, 2005). 


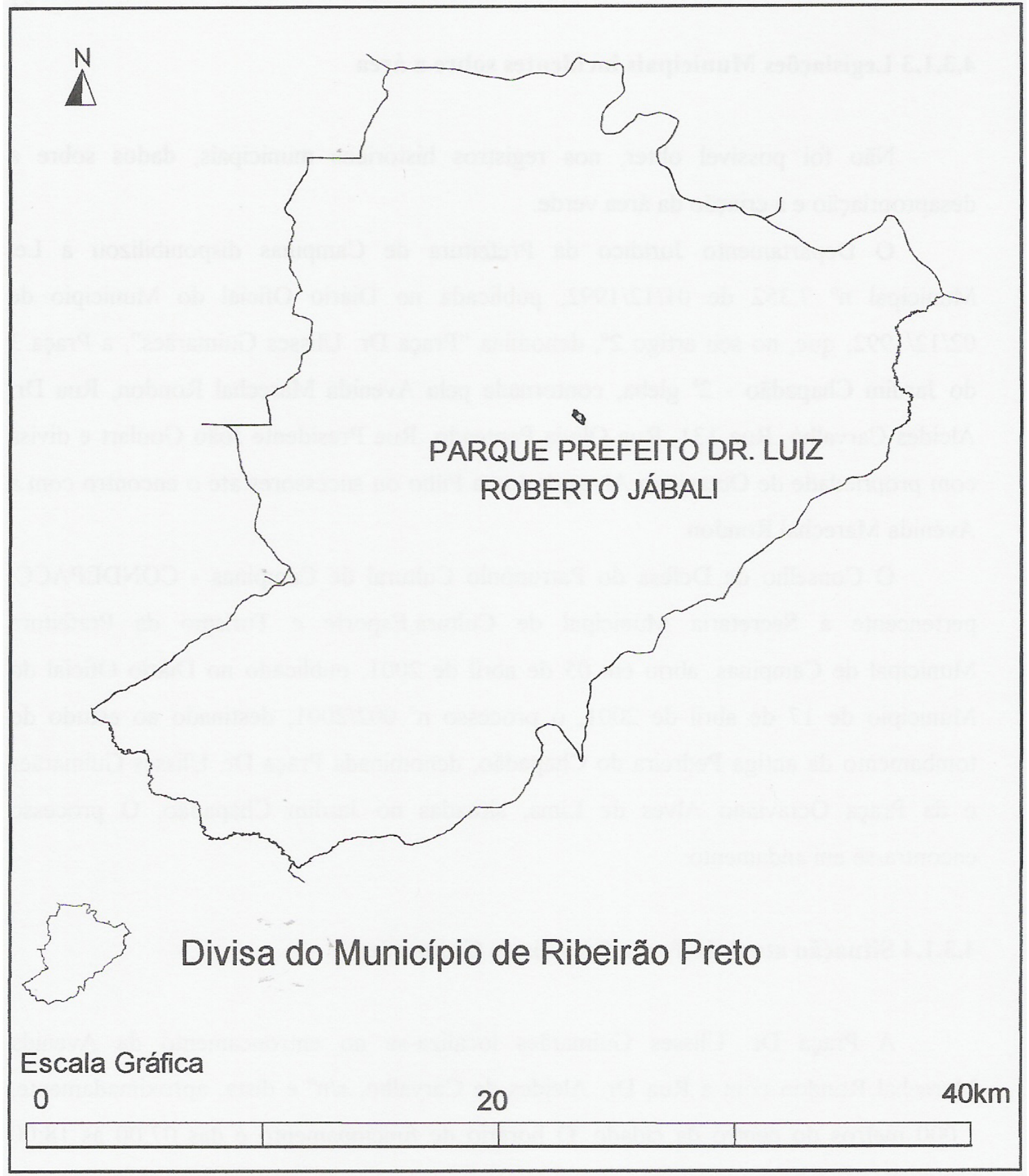

Fonte: Adaptado de Prefeitura Municipal de Ribeirão Preto (2005)

Figura 5 - Localização do Parque Prefeito Luiz Roberto Jábali no Município de Ribeirão Preto 
Inaugurado em 18 de novembro de 2000, o parque foi transformado no maior espaço de lazer da cidade. O projeto elaborado pela prefeitura, transformou o local num ambiente ideal para passeios e caminhadas. Foram construídos cachoeiras e lagos artificiais próximos a uma Praça de Eventos. Entrecortada por trilhas asfaltadas, a área é ideal para caminhadas e passeios de bicicleta. Também foi concebido um espaço para apresentações ao ar livre, com palco e capacidade para 20 mil pessoas (Prefeitura Municipal de Ribeirão Preto, 2005).

$\mathrm{O}$ parque possui três setores distintos. $\mathrm{Na}$ entrada fica o estacionamento, com capacidade para 200 carros; o setor destinado a eventos, possui $15.000 \mathrm{~m}^{2}$ e pode abrigar até 20 mil pessoas ou mais; no entorno, ficam as trilhas.

\subsubsection{Situação da área durante a atividade de extração do minério}

O $2^{\circ}$ Distrito (São Paulo) do DNPM não possui mais esse processo em seus arquivos e comunica que houve sua destruição na sede do DNPM em Brasília, em $01 / 11 / 1989$.

A área foi legalmente explorada, segundo o Decreto-Lei $\mathrm{n}^{\circ} 227$ de 28 de fevereiro de 1967 (Código de Mineração). Em 22 de setembro de 1976, foi protocolizado no DNPM, o requerimento de licenciamento para exploração da substância mineral basalto, perfazendo uma poligonal DNPM de 30,00 ha. O Processo recebeu $n^{\circ} 853.569 / 76$.

Durante o ano de 1977, foram cumpridas pelo requerente, exigências para esclarecimentos feitas pelo órgão responsável e em 07/03/1979, foi publicada no Diário Oficial da União, a autorização para extração do bem mineral citado na área requerida.

Não há registros de solicitação de fechamento da mina; porém se a autorização para exploração foi emitida em 1979 e o processo foi destruído no ano de 1989, a exploração do minério no local durou aproximadamente 10 anos.

Devido à falta de acesso ao processo, não foi possível analisar o plano de exploração da área e saber da existência de um projeto futuro de recuperação para o local. 
Quanto à autorização estadual, é possível afirmar a inexistência de uma Licença de Operação para o empreendimento, já que os empreendimentos mineiros já existentes só começaram a ser regularizados a partir do ano de 1989, com as Resoluções SMA nº 18/89, CONAMA nº 09/90 e no 10/90 e SMA no $26 / 93$.

O Município de Ribeirão Preto também não dispunha de legislação específica para a exploração de basalto na região.

A área do Parque Prefeito Luiz Roberto Jábali era de propriedade de Companhia City de Desenvolvimento, Anastácio Empreendimentos Imobiliários e Participações LTDA e São Bernardo - Imobiliária Administração e Representação LTDA. A atividade extrativa deu-se pela empresa Leão \& Leão LTDA., grupo responsável pela extração de basalto em diversas áreas na região de Ribeirão Preto.

Em 21 de julho de 2.000, foi lavrada a escritura de desapropriação amigável entre os proprietários da área subscritos e a Prefeitura Municipal de Ribeirão Preto representada pelo seu Prefeito Dr. Luiz Roberto Jábali, conforme Decreto $n^{\circ} 163$ de 27 de junho de 2.000, publicado no Diário Oficial do Município de 28 de junho de 2.000; o referido imóvel com uma área de $138.700,25 \mathrm{~m}^{2}$ foi declarado de utilidade pública.

A construção do Parque Prefeito Luiz Roberto Jábali foi realizada pela prefeitura, no ano de 2.000, segundo arquivos da Prefeitura Municipal de Ribeirão Preto. O parque foi inaugurado em novembro de 2.000 .

\subsubsection{Legislações Municipais incidentes sobre a área}

O "Parque Prefeito Luiz Roberto Jábali", inicialmente denominado "Parque Curupira”, foi constituído através da Lei complementar $n^{0} 1.009$ de 15 de maio de 2.000, que define o imóvel e declara a área de interesse especial. A lei descreve a área em seu artigo $1^{\circ}$, destaca a preservação da vegetação já existente no local e a recomposição da originária com o plantio de novas espécies, além de permitir a instalação de equipamentos de lazer e contemplação, de vias de circulação de pedestres, de mobiliários e construções compatíveis com a destinação do parque. A adequação do sistema viário local, através do prolongamento e/ou abertura de vias públicas, a fim de 
proporcionar pleno acesso ao "Parque Curupira", fica autorizada para o Poder Executivo Municipal, no artigo $2^{\circ}$ da referida lei.

O Decreto $n^{\circ} 163$ de 27 de junho de 2.000 declara de utilidade pública o imóvel descrito na escritura de desapropriação amigável ou judicial de 21 de julho de 2.000 , de propriedade de Companhia City de Desenvolvimento, Anastácio Imobiliária S/A e São Bernardo - Empreendimentos e Participações Ltda, para fins de implantação do "Parque Curupira", criado pela Lei Complementar nº 1.009/00.

O Decreto $\mathrm{n}^{\mathrm{o}} 630$ de 14 de novembro de 2.000 delega, em seu artigo $1^{\mathrm{o}}$, à Secretaria de Planejamento e Gestão Ambiental as atribuições de gerenciamento e administração do "Parque Curupira".

A Lei Complementar $n^{\circ} 1.204$ de 10 de abril de 2.001 acrescenta o $\S 3^{\circ}$ ao Artigo $1^{\mathrm{o}}$ da Lei Complementar $\mathrm{n}^{\mathrm{o}} 1.009 / 00$ de 15 de maio de 2.000: "fica proibida a comercialização e uso de bebidas alcoólicas, cigarros, charutos e similares nas dependências do Parque Curupira".

A Lei Complementar $n^{0} 1.272$ de 28 de novembro de 2.001 dispõe sobre $o$ Parque Curupira e estabelece disposições correlatas, cria restrições de uso de seu entorno e dá outras providências. Nos artigos $1^{\circ}$ a $8^{\circ}$ e em seus parágrafos e incisos, estabelece o zoneamento no entorno do Parque Curupira, definindo Zona de Entorno Imediato, Zona de Proteção à Paisagem, Zona de transição "A" e Zona de Transição "B" e estabelecendo os tipos de edificações permitidos nas respectivas zonas. O Artigo $9^{\circ}$ estabelece algumas restrições ao uso no entorno do Parque Curupira: proíbe a instalação e funcionamento de serviços e atividades geradoras de ruídos e emissões que causem danos à fauna, flora e infra-estrutura e usuários do parque; "as laterais e fundos dos lotes anexos à área do Parque Curupira deverão manter, sem edificação, uma faixa de proteção com 3,0 metros de largura, onde é vedado o uso de fogo para qualquer fim"; obriga o uso de fiação isolada nas calçadas adjacentes à bordadura do Parque e proíbe a instalação de elementos de comunicação visual em muros e alambrados do Parque.

O Decreto $n^{\circ} 185$ de 23 de junho de 2.003 regulamenta a Lei Complementar $n^{\circ}$ 1.009/00 de 15 de maio de 2000 e decreta as finalidades do Parque Curupira, subordina ao diretor do Departamento de Gestão Ambiental da Secretaria de Planejamento e 
Gestão Ambiental a direção do Parque Curupira, relacionando as atividades vedadas na área pertencente ao Parque Curupira. Também subdivide o Parque Curupira em zonas e destina a elas determinadas atividades e promulga o horário de funcionamento do Parque Curupira: das 6 às 21 horas, no período do ano em que vigorar o horário de verão e das 6 às 20 horas, nos demais meses do ano.

A Lei $\mathrm{n}^{\mathrm{o}}$ 10.186, de 15 de setembro de 2004, em seu Artigo $1^{\mathrm{o}}$, altera a denominação de CURUPIRA PARQUE DA CIDADE para "PARQUE PREFEITO LUIZ ROBERTO JÁBALI", à área de implantação do Programa de Estruturação Urbana e Ambiental, criada pela Lei Municipal $n^{\circ}$ 7105, de 16 de junho de 1995 e Lei Complementar $n^{\circ} 1009$, de 15 de maio de 2000. No seu Artigo 2º prevê a alteração da nomenclatura altamente gravada nas dependências do Parque Ecológico Municipal pelo Executivo Municipal.

O artigo 92 da Lei Complementar no 1.616 de 19 de janeiro de 2004, que institui o Código do Meio Ambiente, preconiza sobre a recuperação de áreas de mineração abandonadas ou desativadas, responsabilidade do minerador. A adoção de medidas pelo empreendedor de garantia de estabilidade dos taludes em minerações paralisadas são relatadas no artigo 93 do referido Código.

\subsubsection{Situação atual do Parque Prefeito Luiz Roberto Jábali}

O Parque Prefeito Luiz Roberto Jábali localiza-se à Avenida Costábile Romano, 337, Bairro Ribeirânia. O Parque limita-se ao Norte e ao Sul, com terras da Companhia City de Desenvolvimento; a Leste, com terras do espólio de Laurindo G. Farinha e terras da Imobiliária e Incorporadora Jardim Umuarama Ltda. (imóvel rural) e, a Oeste, com a Avenida Costábile Romano. O horário de funcionamento do parque tem sido seguido.

Conforme arquivos da Prefeitura Municipal de Ribeirão Preto, o Parque foi entregue à população com as seguintes benfeitorias: 4.000 metros de alambrado, pistas internas e pátio de estacionamento asfaltado, 4.000 mudas de árvores plantadas, poço profundo com vazão de 25.000 litros/hora, sistema de recalque para formação das quedas d'água, palco para apresentações artísticas-culturais e lagos artificiais. 
$\mathrm{Na}$ visita à área foi possível confirmar a existência das seguintes benfeitorias:

- Área central do parque: Praça de Eventos, na grande cava de pedreira, resultante da exploração de basalto (Figura 6), onde estão instaladas pistas para caminhadas e para passeios de bicicleta, 06 lagos artificiais, palco para apresentações, gramado (com cerca de $8.000 \mathrm{~m}^{2}$ ), para usos múltiplos; 02 cachoeiras artificiais (Figura 7) com 30 metros de queda e ainda 02 outras menores (nas duas quedas principais, a água circula a uma vazão de $1.500 \mathrm{~m}^{3} /$ hora, sendo $1.000 \mathrm{~m}^{3} / \mathrm{h}$ destinados para a maior e 500 $\mathrm{m}^{3} /$ hora para a menor).

口 Área externa à Praça de Eventos: 12.000 metros de pistas asfaltadas destinadas a caminhadas e ciclismo. A ciclofaixa encontra-se demarcada na pista (Figura 8), de modo a se evitar acidentes com os pedestres.

口 Área externa à Praça de Eventos (faixa limítrofe à Avenida Costábile Romano): maciços de vegetação natural (Figura 9), que recebem manejo adequado e permanente, de modo a garantir a recuperação dos mesmos .

- Ponto mais alto do Parque (altitude de 580 metros): situam-se o reservatório de água que abastece o Parque, bebedouros e duchas para banhos (Figura 10). A capacidade total do reservatório é de 100.000 litros destinados a: irrigação, combate a incêndios, consumo humano após cloração e complementação do nível dos lagos, quando necessário.

口 Entrada do parque: situam-se o estacionamento (Figura 11) e a área de alimentação (Figura 12); o estacionamento comporta em torno de 200 carros de passeio.

口 A área do Parque Prefeito Luiz Roberto Jábali é cercada com alambrado e possui, além da vegetação implantada (Figura 13) para o parque, um fragmento florestal remanescente, em estágio avançado de regeneração, de Floresta Estacional Semidecidual, (Figura 9) cujas espécies que mais se destacam, de acordo com os arquivos da Prefeitura Municipal de Ribeirão Preto, são: abiu (Pouteria ramiflora Mart.) Radik.), açoita-cavalo (Luehea divaricata Mart.), angico (Anadenanthera macrocarpa (Benth.) Brenan), aroeira (Myracrodruon urundeuva Fr. All.), amendoim (Pterogyne nitens Tul.), cafezinho (Rhamnidium elaeocarpus Reiss.), cedro (Cedrela fissilis Vell.), embaúba (Cecropia pachystachya Trec.), embira de sapo (Lonchocarpus guillemineanus 
(Tul.) Malme), embiruçu (Eriotheca pubescens Schott et Endl.), farinha-seca (Albizia hasslerii (Chodat) Burr.), figueira branca (Ficus guaranitica Schodat), goiabeira (Psidium guajava L.), grão de galo (Cordia superba Cham.), grumixama (Eugenia brasiliensis Lam.), guariroba (Syagrus oleracea (Mart.) Becc.), ingá (Inga uruguensis Hook. \& Arn.), ipê amarelo (Tabebuia alba (Cham.) Sandw.), ipê rosa (Tabebuia heptaphylla (Vell.) Tol.), jacarandá (Dalbergia nigra (Vell.) Allemao ex Benth.), jaracatiá (Jacaratia spinosa (Aubl.) A. DC.), jenipapo (Genipa americana L.), jequitibá branco (Cariniana estrellensis (Raddi) Kuntze), jerivá (Syagrus romanzoffiana (Cham.) Glassm.), lixa (Aloysia virgata (Ruiz et Pav.) A. L. Juss.), macaúba (Acrocomia acuelata (Jacq.) Lodd.), mamica de porca (Zanthoxylum rhoifolium Lam.), mutambo (Guazuma ulmifolia Lam.), paineira (Chorisia speciosa St. Hil.), pau-brasil (Caesalpinia echinata Lam.), pau-ferro (Caesalpinia férrea Mart. ex Tul.), pitanga (Eugenia uniflora L.), peito de pombo (Tapirira guianensis Aubl.), sapuvão (Machaerium stipitatum (DC.) Vogel), tamanqueira (Aegiphila sellowiana Cham.) e tamboril (Enterolobium contortisiliquum (Vell.) Morong).

- A fauna silvestre é representada por aves como o pica-pau e o quero-quero, por mamíferos como o sagui ou mico-estrela, por répteis e tantos outros (Prefeitura Municipal de Ribeirão Preto, 2005).

A área possui um plano de manejo da vegetação natural e implantada elaborado em março de 2.001, com o intuito de administrar os plantios realizados destinados à recomposição florestal, controlar as espécies invasoras e manejar a área gramada. Foi assinado entre a Prefeitura Municipal de Ribeirão Preto e o Departamento Estadual de Proteção aos Recursos Naturais Renováveis - DEPRN, um termo de compromisso, comprometendo-se a primeira a executar as medidas previstas no Plano de Manejo apresentado.

A manutenção do Parque Prefeito Luiz Roberto Jábali (e de cinco outros parques do Município de Ribeirão Preto) é feita pela Companhia de Desenvolvimento de Ribeirão Preto - CODERP, fundada em 1972, como uma empresa de economia mista. A Lei Complementar n 1.215 , de 04 de maio de 2001, publicada no Diário Oficial do 
Município de 17 de maio de 2.001, regulamenta os convênios da Prefeitura Municipal de Ribeirão Preto com empresas, associações culturais, esportivas ou de serviços, Universidades, instituições de ensino, associações de profisssionais ou de classe, sindicatos, associações de moradores e similares, para a estruturação e manutenção dos parques e das Unidades de Conservação municipais.

O Parque Prefeito Luiz Roberto Jábali está sob responsabilidade de seis funcionários, no total, entre faxineiros, serventes e responsáveis por manutenção geral de equipamentos. Há um chefe geral, que supervisiona os outros parques e cinco guardas civis metropolitanos, que se dividem nos períodos matutino, vespertino e noturno da seguinte maneira: de segunda a sexta-feira, dois pela manhã, dois pela tarde e um de noite e madrugada; de finais de semana, dois a mais são escalados, para permanecerem três no período da manhã, três à tarde e um à noite.

O parque apresenta-se muito bem cuidado; não se vê papéis jogados no chão e sinais de abandono quanto à manutenção.

Nas áreas com riscos de desmoronamento de pedaços de rocha, resultantes da extração mineral outrora realizada no local, há placas indicativas de "PERIGO DESMORONAMENTO", faixas amarelas de isolamento dos locais mais suscetíveis à queda de materiais (Figura 14) e emendas com ganchos, quando suficiente, a fim de evitar acidentes com a população visitante.

O estado de conservação das benfeitorias existentes no Parque Prefeito Luiz Roberto Jábali foram avaliados e conceituados, conforme parâmetros a seguir:

a $\quad$ administração - nota 0

Segundo o administrador local, há previsão para instalação, ainda no ano de 2.005, de uma construção com administração, guarita da guarda municipal e ambulatório.

ㅁ alambrado - nota 5 (Figura 17)

ㅁ bancos - nota 4 
ㅁ banheiros - nota 5

O sanitário feminino apresenta quatro lavatórios e cinco boxes com bacias sanitárias, sendo um deles para deficiente físico. O sanitário masculino apresenta quatro lavatórios, quatro mictórios e cinco boxes com bacias sanitárias, sendo um deles para deficiente físico. Não faltam, nos banheiros, os produtos de higiene necessários à utilização do local (papel higiênico, sabonete e papel toalha).

ㅁ bebedouros - nota 4

Existem quatro bebedouros no parque inteiro, quantidade considerada pequena, haja vista o tamanho do local. Há testemunhos de reclamação por parte da população, quanto ao número de bebedouros existentes no parque.

․ cachoeira (s) - nota 5

Existem quatro cachoeiras em perfeito funcionamento no Parque Prefeito Luiz Roberto Jábali, que, ocasionalmente apresentam problemas, solucionados pelos responsáveis pela manutenção local.

duchas - nota 5

- equipamentos para ginástica - nota 5

Há três áreas em diferentes locais do parque para a realização de atividades físicas pela população. Os equipamentos são de madeira e ferro (Figura 16).

a gramado - nota 4

A área gramada pertencente à área central do parque apresenta problemas de drenagem (Figura 15), aspecto negativo encontrado no Parque Prefeito Luiz Roberto Jábali, apontado como um elemento a ser observado e corrigido.

guarita - nota 4 
a $\quad$ lago (s) - nota 4

No trabalho de campo, foi observado o transbordamento de um dos lagos (Figura 18), num dia de muita chuva. Apesar de ser um efeito negativo esporádico, a capacidade de armazenamento de água desse lago deve ser reavaliada e o local reformado, caso necessário.

- lanchonete (área de alimentação) - nota 5

A lanchonete (Figura 12) foi construída pela Prefeitura em convênio com a Coca-Cola. O funcionamento foi cedido pela Prefeitura a três entidades de caridade, que dividem os lucros obtidos. Existe também uma barraca, conhecida por quiosque do coco, com lucros divididos entre uma entidade filantrópica e o responsável do local.

ㄴ lixeiras - nota 5

O parque possui uma grande quantidade de lixeiras, distribuídas por todo o local, subdivididas em cestos menores, ao longo das pistas de caminhadas e lixeiras maiores, próximas ao bar e estacionamento.

ㅁ monumentos - nota 5

O Parque Prefeito Luiz Roberto Jábali possui quatro monumentos em perfeitos estados de conservação: Monumento à Bíblia, que traz curiosidades presentes na Bíblia, Monumento ao Curupira, Monumento ao palco de apresentações e Monumento ao Parque, informando a mudança de nome do parque.

$\mathrm{Na}$ entrada do Parque, há um painel apresentando um "layout" do local, com informações históricas do parque e recomendações importantes para os visitantes (Figura 19).

$\quad$ palco para apresentações - nota 5

口 pátio de estacionamento - nota 5 
口 pistas para caminhadas - nota 5

As pistas para caminhadas possuem marcas indicativas de metragem no chão e de trânsito para pedestres (de um lado) e tráfego para bicicletas e patins, de outro lado.

몬 para bicicletas - nota 5

口 placas explicativas - nota 5

O parque inteiro possui placas indicativas de trânsito para pedestres, bicicletas, patins (Figura 8), direção das duchas, bebedouros (Figura 20). As atividades e locais do parque estão muito bem sinalizados.

"playground" - nota 5

portaria - nota 0

- quadras de jogos - nota 0

Este tipo de atividade não é permitido no parque, conforme legislação vigente, com o intuito de preservação do habitat da fauna presente no local.

quiosques - nota 5

Os quiosques do Parque Prefeito Luiz Roberto Jábali localizam-se próximo à área de alimentação.

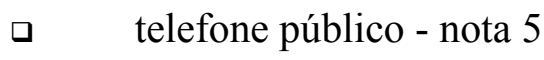

• vegetação nativa implantada (espécies arbóreas isoladas) - nota 5

- vegetação nativa remanescente (fragmento florestal) - nota 5 
o outros:

• edificação reservada para prática de tai-chi-chuan - nota 5

O Parque Prefeito Luiz Roberto Jábali possui convênio com empresas colaboradoras, denominadas parceiras no "Programa de Estruturação e Manutenção do Parque". Estas empresas são identificadas no acesso aos sanitários e junto à área de alimentação (Figura 21) e são: 3M, Gael, Socicam, Coca-Cola, Cia de Bebidas Ipiranga, Evac e Pró-Verde Paisagismo.

A água que abastece o parque é de poço artesiano local e do Departamento de Água e Esgotos de Ribeirão Preto - DAERP.

O acesso ao Parque Prefeito Luiz Roberto Jábali pode ser feito por três linhas de ônibus municipais. As placas indicativas ao local apontam Ribeirânia, bairro onde se situa a referida área verde e levam, do centro, diretamente à Avenida Costábile Romano.

O "site” do Município de Ribeirão Preto traz o Parque Prefeito Luiz Roberto Jábali como um dos atrativos turísticos da cidade, destacando sua história e algumas fotografias locais. Alguns "folders" de divulgação do parque, como ponto turístico do Município, foram elaborados: um, datado de novembro de 2000, traz informações para os usuários em geral, como histórico do parque, recomendações importantes na sua utilização, mapa de acesso e mapa do parque; outro, datado de julho de 2001 é um informativo de atividades no parque para escolas e orientações gerais para visitas de recreação.

Há registros da Prefeitura Municipal de Ribeirão Preto da visitação da população no Parque Prefeito Luiz Roberto Jábali. Os dados apresentam, em média, a visita de 7.000 pessoas aos sábados e domingos e 5.000 pessoas durante a semana, totalizando por volta de 48.000 visitas mensais. 


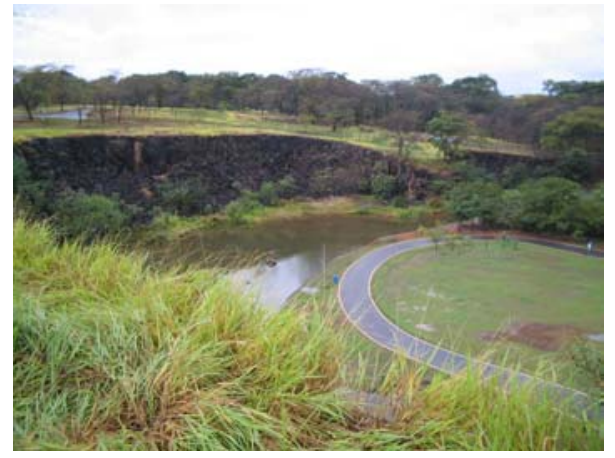

Figura 6 - Cava da pedreira

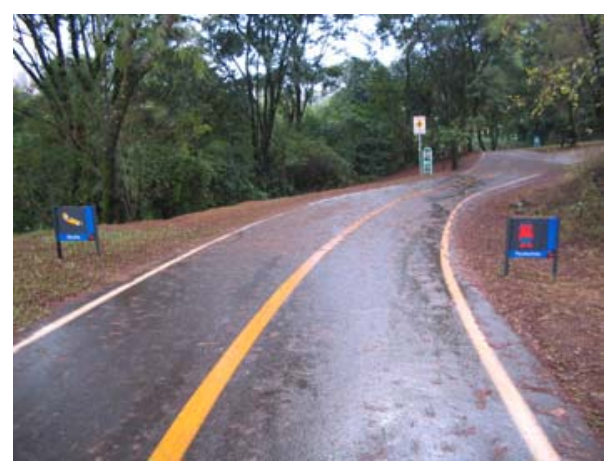

Figura 8 - Faixa para pedestres e bicicletas

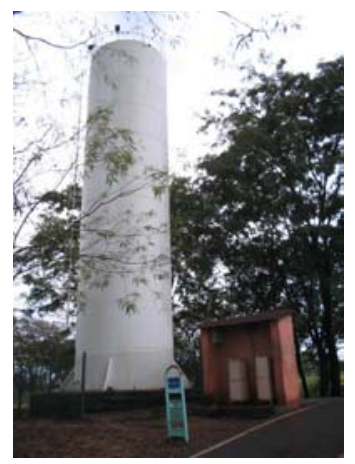

Figura 10 - Reservatório de água e bebedouros

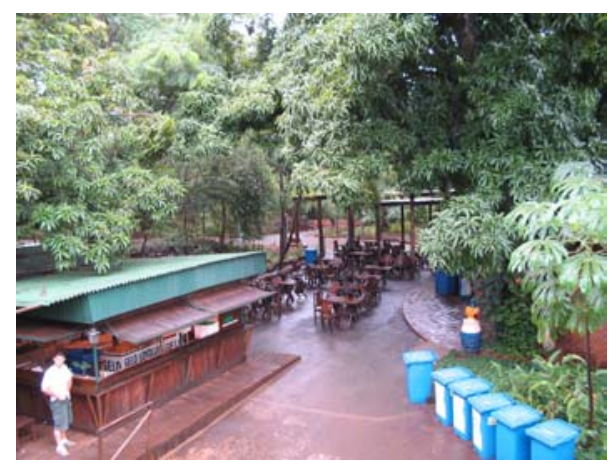

Figura 12 - Área de alimentação

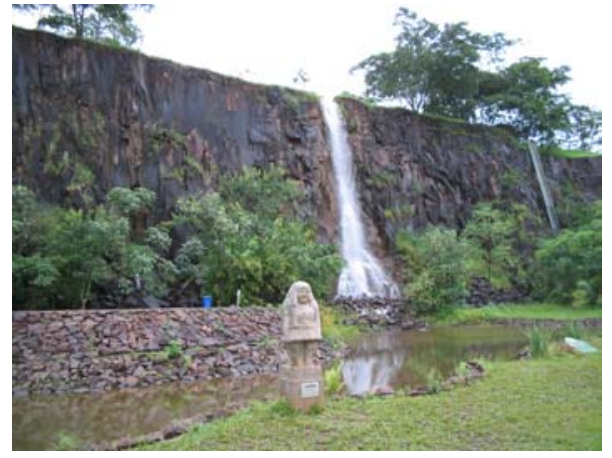

Figura 7 - Cachoeira artificial

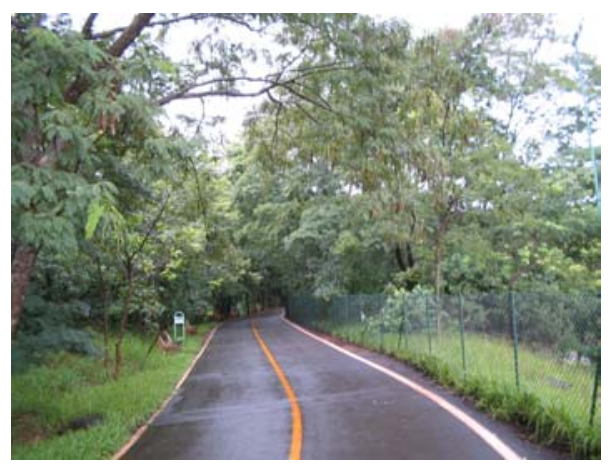

Figura 9 - Maciço de vegetação natural

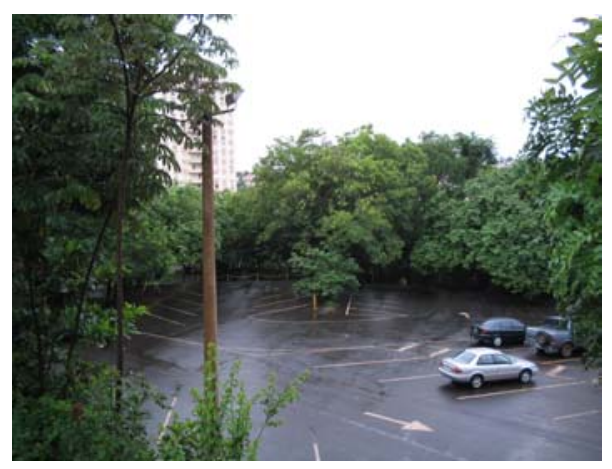

Figura 11 - Estacionamento

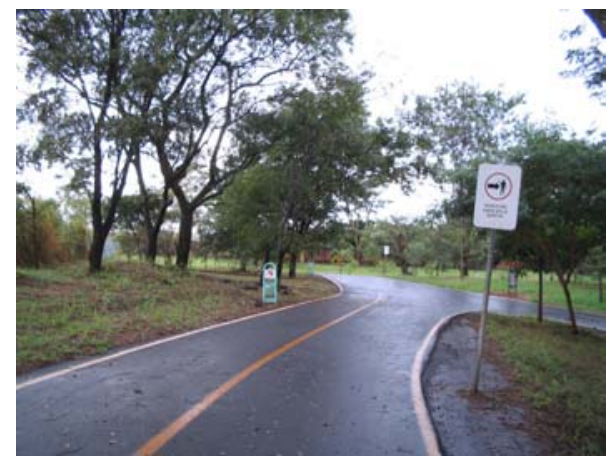

Figura 13 - Vegetação implantada no parque 


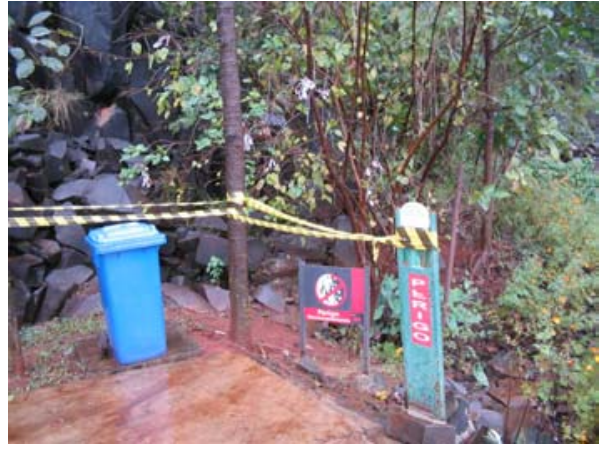

Figura 14 - Aviso de "PERIGO” em áreas de risco

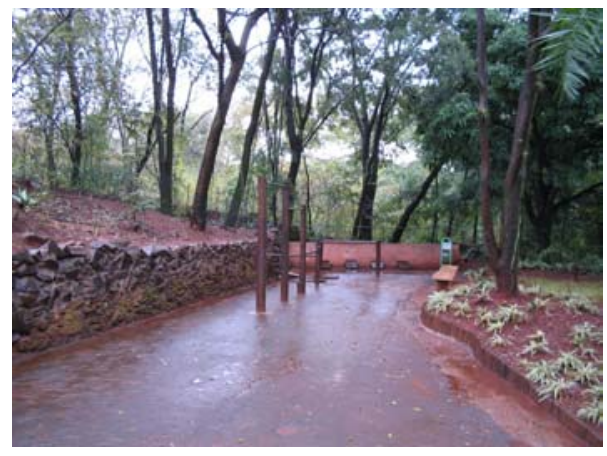

Figura 16 - Equipamentos para ginástica

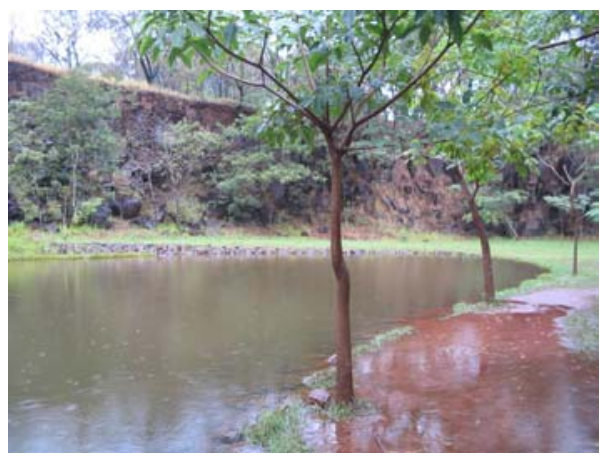

Figura 18 - Lago com transbordo de água

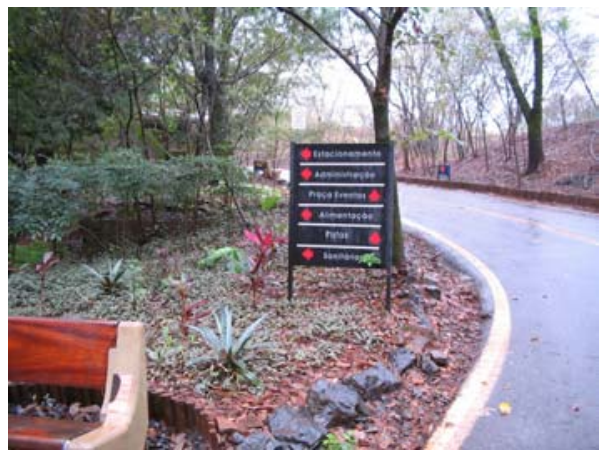

Figura 20 - Placas indicativas de direção

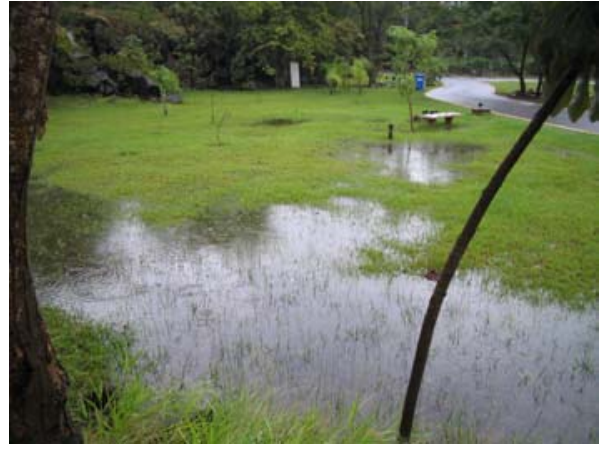

Figura 15 - Gramado com problemas de drenagem

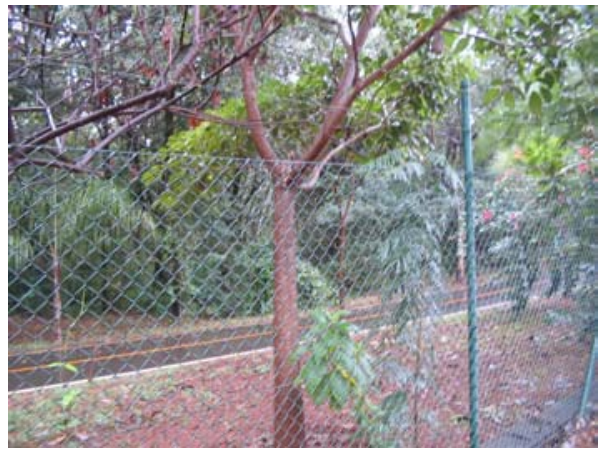

Figura 17 - Alambrado

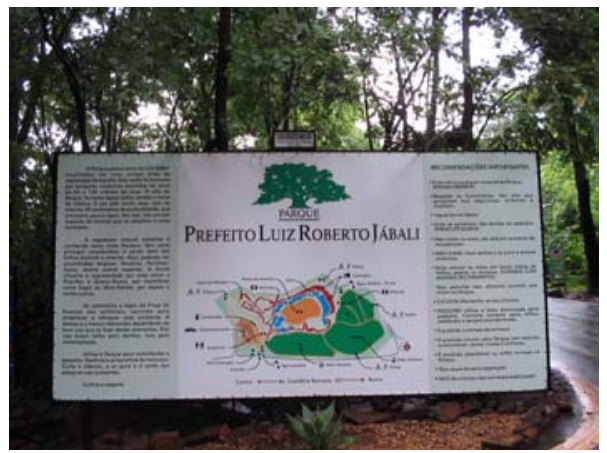

Figura 19 - Painel na entrada do Parque

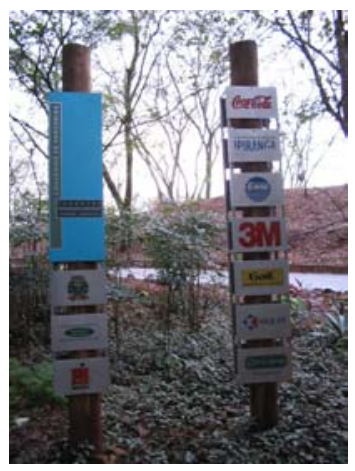

Figura 21 - Empresas parceiras do Parque 


\subsection{Parque do Varvito / Município de Itu / SP}

\subsubsection{Aspectos locais da área de estudo}

\subsubsection{Características gerais do Parque do Varvito}

O Parque do Varvito foi construído ao redor de uma pedreira de varvito, na região Centro-Norte do Município de Itu, nas coordenadas UTM $262.741 \mathrm{~m}$ E e 7.424.917 m N ou coordenadas geográficas $23^{\circ} 16^{\prime}$ Sul e $47^{\circ} 19^{\prime}$ Oeste, numa área de $44.346 \mathrm{~m}^{2}$ (Figura 22).

Inaugurado no dia 23 de julho de 1995, o parque recebe anualmente muitas pessoas entre turistas, estudantes e pesquisadores. O Parque do Varvito, além de oferecer ambiente agradável em contato com a natureza e com painéis didáticos sobre a manifestação geológica, mantém outros atrativos para os visitantes: lanchonete/restaurantes, bosques, lago, cascata, quiosques, "playground", anfiteatro ao ar livre e espaço para exposições, além de estacionamento para carros, motos e ônibus (PARQUE, s.d.).

\subsubsection{Situação da área durante a atividade de extração do minério}

O registro histórico que se tem sobre a exploração da Pedreira de Itu, para a obtenção de suas famosas lajes, exposto nos murais do Parque do Varvito, data de, aproximadamente, 1720. É muito provável porém, que o uso do varvito como pedra de construção seja contemporâneo da fundação da cidade de Itu, em 1610. O artista ituano Miguelzinho Dutra reproduziu, em 1847, em painel uma vista da pedreira.

A pedreira, em tempos idos, fazia parte de uma extensa propriedade rural, com 98 alqueires (219,52 ha) aproximadamente (Navarro, 1993). No início do século XIX, o latifúndio pertencia ao Sr Antônio Inácio dos Santos, que, ao falecer, deixou essa imensa

gleba para seus herdeiros, sua viúva D. Júlia Augusta de Almeida e filhos. À Dona Júlia 


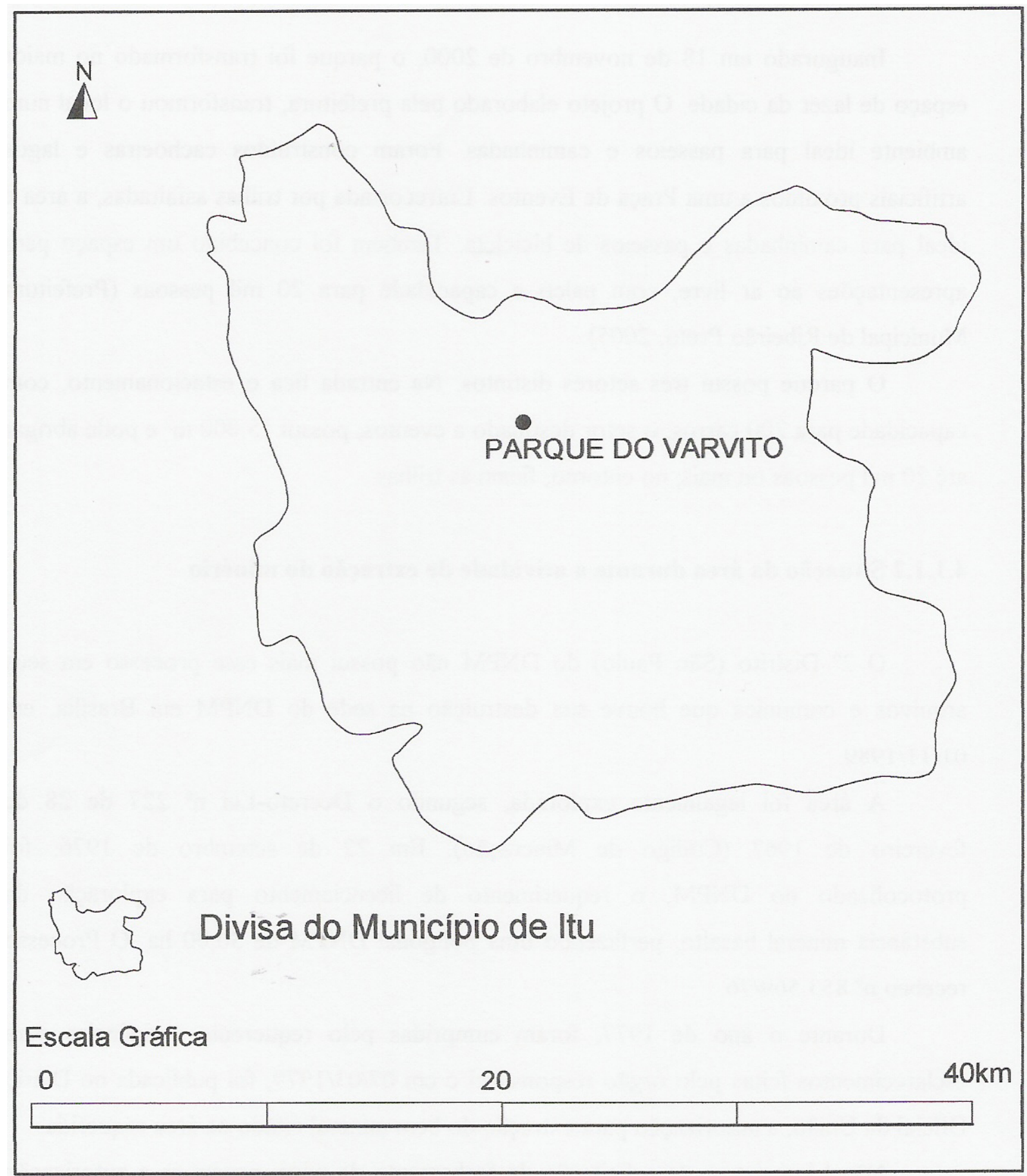

Fonte: Adaptado de SMA (2000)

Figura 22 - Localização do Parque do Varvito no Município de Itu 
Augusta, coube a "Chácara da Pedreira", de 21 alqueires (47,04 ha), onde se localizava a Pedreira do Varvito, nos arredores da cidade, no Bairro Alto. Essa propriedade limitavase com as Estradas Guatapendá (atual do Jacu), do Barreto e Rio Itaim-Mirim.

A "Chácara da Pedreira”, em 1926, foi desmembrada em duas partes iguais, devido ao falecimento do Sr. Felício Iarussi, com quem se casara Dona Júlia Augusta de Almeida. Uma metade ficou para a viúva e a outra para a única filha do casal, Dona Benedita Iarussi Galvão, casada com o Sr. Francisco Mendes Galvão. Ao falecer, em 11 de agosto de 1959, Dona Júlia Augusta deixou como herança, os 10 alqueires e meio (23,52 ha) dessa antiga chácara para seus 12 filhos do casamento anterior. O Sr. Renato Inácio dos Santos, seu filho mais velho, casado com Dona Sebastiana Dias Pacheco, na década de 70, vendeu ao Sr. Osmar Peixoto, os 2 alqueires (4,48 ha) que herdara, no qual estava incluído um lado inexplorado da pedreira. A firma do Sr Osmar, desde 1968, vinha extraindo o varvito, num terreno, também de 2 alqueires, vizinho ao que adquirira do Sr Renato, separados apenas por uma estrada de acesso (Navarro, 1993).

Em 1974, o Conselho de Defesa do Patrimônio Histórico, Artístico, Arqueológico e Turismo do Estado de São Paulo (CONDEPHAAT) tombou a pedreira tradicional ou "velha" (restrita a uma área de $7.420 \mathrm{~m}^{2}$ ) em atenção às solicitações do Prefeito vigente e do Secretário Municipal de Cultura e Turismo. Efetivado o tombamento, a firma do Sr. Osmar, devidamente autorizada pelo Ministério das Minas e Energia, passou para o terreno contíguo de sua propriedade e deu início à extração do varvito na pedreira "nova" (Navarro, 1993).

Todo este registro histórico mostra que a extração do varvito foi feita na área do parque durante anos e anos, e teve fim em 1974, com o tombamento do local. Portanto, fica clara a exploração do minério para aplicação no calçamento de cidades e no reforço a alicerces de construções, sem a aplicação de planos de exploração e recuperação.

A extração do varvito era realizada pelos próprios proprietários dos terrenos, onde o minério se depositava.

A Prefeitura da Estância Turística de Itu desapropriou a área do atual Parque do Varvito em 05 de maio de 1979 e iniciou, em outubro de 1993, as obras para a implantação do parque, que foi inaugurado em julho de 1995. 


\subsubsection{Legislações Municipais incidentes sobre a área}

O "Parque do Varvito" foi tombado pela Resolução sem numeração da Secretaria de Estado da Cultura, Esportes e Turismo, de 18 de março de 1974 (SMA, 2000).

A desapropriação de toda a área da pedreira e arredores, num total de $44.346 \mathrm{~m}^{2}$, incluindo a parte anteriormente tombada, foi feita pela Prefeitura Municipal de Itu, em 1993.

\subsubsection{Situação atual do Parque do Varvito}

O Parque do Varvito localiza-se à Rua Parque do Varvito $s / \mathrm{n}^{\circ}$, Parque Nossa Senhora da Candelária, na zona urbana da cidade de Itu. O horário de funcionamento do parque é das 07:00 às 17:00 horas, de terça-feira a domingo.

De acordo com notícias jornalísticas municipais, na época de inauguração, "folders" sobre o parque e, conforme observações no trabalho de campo, entre as atrações do parque estão o "Bosque Bucólico" (Figura 23), a "Cascata do Antanho" e o "Lago dos Fósseis" (Figura 24), a "Vereda dos Seixos" (Figura 25), a "Praça Cívica" (Figura 26), o "Lago Jurássico" (Figura 27), o "Anfiteatro Gondvana" (Figura 28), a "Gruta Lágrima do Tempo", a "Trilha dos Bentônicos" (FIGURA 29), o "Parque Cenozóico (Figura 37),"Bosque dos Matacões" - quiosques (Figura 30), lanchonete, "playground" (Figura 31) e estacionamento para carros, motos e ônibus (Figura 32).

Além disso, a área do Parque do Varvito é cercada com alambrado (Figura 33) e possui vegetação implantada (Figura 23) para o parque e espécies vegetais resultantes de regeneração natural causada pelo abandono das atividades minerárias.

A Pedreira do Varvito, não possui fragmento florestal remanescente de vegetação original da Mata Atlântica. As espécies vegetais nativas encontradas na área, identificadas por placas que possuem seus nomes vulgar e científico, são: amendoim bravo (Platypodium elegans Vogel), angico (Anadenanthera macrocarpa (Benth.) Brenan), aroeira brava (Lithraea molleoides (Vell.) Engl.), aroeira salsa (Schinus molle L.), bico-de-pato (Machaerium acutifolium Vogel), cabreuva (Myrocarpus frondosus 
Allemao), cambará (Gochnatia polymorpha (Less.) Cabr.), embaúba (Cecropia pachystachya Trec.), figueiras (Ficus spp), goiabeira (Psidium guajava L.), guarantã (Esenbeckia leiocarpa Engl.), ipê (Tabebuia chrysotricha (Mart. ex DC.) Standl.), ipê felpudo (Zeyheria tuberculosa (Vell.) Bur.), jacarandá (Dalbergia nigra (Vell.) Allemao ex Benth.), guapuruvu (Schizolobium parahyba (Vell.) S.F. Blake), mulungu (Erythrina crista-galli L.), oiti da praia (Licania tomentosa (Benth.) Fritsch.), pata de vaca (Bauhinia forficata Link), pau-brasil (Caesalpinia echinata Lam.), pau-amendoim (Pterogyne nitens Tul.). Também se identificou algumas espécies vegetais exóticas implantadas, como: canela (Cinnamomum zeylanicum Nees), caracasana (Euphorbia cotinifolia L.), chapéu de sol (Terminalia catappa L.) e coração de negro (Albizia falcataria (L.) Fosberg).

Não há registros da fauna no Parque do Varvito.

A manutenção do Parque do Varvito é feita pela Prefeitura Municipal de Itu. O Parque está sob responsabilidade de oito funcionários, no total, entre administrador, faxineiros, serventes e responsáveis por serviços gerais. Há dois guardas municipais responsáveis pela segurança do Parque do Varvito, que se dividem nos períodos diurno e noturno.

O parque apresenta-se bem cuidado, quanto à faxina geral. As placas explicativas do processo geológico ocorrido no local há milhões de anos, referente ao Período da Glaciação e a história do parque, não se encontram num bom estado de conservação, estando, muitas vezes, apagadas e inelegíveis. Segundo o administrador do parque, há um projeto a caminho prevendo a reforma dos painéis, que apresentará os textos em português e inglês, a fim de atender ao número expressivo de visitantes estrangeiros, devido a importância geológica do local.

A área encontra-se em estabilidade geotécnica, demonstrada, também, pelos vários anos de abandono da lavra de varvito, sem acidentes causados pelo desmoronamento de pedaços de rocha.

Os estados de conservação das benfeitorias existentes no Parque do Varvito foram avaliados e conceituados, conforme parâmetros a seguir:

$\quad$ administração - nota 5 (Figura 34) 
ㅁ alambrado - nota 5 (Figura 33)

$\quad$ bancos - nota 5 (Figura 35)

ㅁ banheiros - nota 5 (Figura 34)

O sanitário feminino central apresenta três lavatórios e cinco boxes com bacias sanitárias. Havia, nos banheiros, os produtos de higiene necessários à utilização do local (papel higiênico e sabonete, com exceção de papel toalha).

O sanitário masculino não foi visitado.

Não havia, no sanitário feminino, cabine adaptada para deficientes físicos.

ㅁ bebedouros - nota 3

Foram contados cinco bebedouros no Parque do Varvito, no qual dois não funcionavam.

A nota fornecida foi uma média das condições encontradas nos bebedouros do local.

cachoeira (s) - nota 5 (Figura 25)

․ duchas - nota 0

- equipamentos para ginástica - nota 0

ㅁ gramado - nota 5 (Figura 36)

guarita - nota 0

$\quad$ lago (s) - nota 5

O "Lago Jurássico" (Figura 27) apresenta um chafariz central em bom estado de conservação, na parte mais alta do Parque. 
O "Lago dos Fósseis" (Figura 24), na parte mais baixa do parque, localiza-se na "Praça do Eco", junto à "Cascata do Antanho".

- lanchonete (área de alimentação) - nota 5

A lanchonete é terceirizada e possui um contrato de pagamento de aluguel do local com a Prefeitura. Existe um banheiro masculino e um feminino na lanchonete, em complemento aos sanitários localizados na "Praça Cívica".

ㄴ lixeiras - nota 5

Há lixeiras comuns, distribuídas por todo o parque e lixeiras específicas para material reciclável (Figura 37).

monumentos - nota 5

O Parque do Varvito possui um orelhão gigante na Praça Cívica, (Figura 34) próximo aos banheiros e à administração, símbolo da cidade de Itu.

Há um monumento na chegada do Parque, antes da portaria de entrada.

Possui, ainda, um Monumento da Sociedade Brasileira de Paleontologia do Paraná, congratulando-se com o Prefeito de Itu pela construção do Parque do Varvito e uma placa de identificação do Parque, logo na entrada (Figura 38).

口 $\quad$ palco para apresentações - nota 5 (Figura 28)

口 pátio de estacionamento - nota 5 (Figura 32)

$\quad$ pistas para caminhadas - nota 5

口 pistas para bicicletas - nota 0

É proibida a entrada de animais, patins e bicicletas no Parque do Varvito.

口 $\quad$ placas explicativas - nota 3 
O parque inteiro possui placas explicativas do processo geológico ocorrido no local há milhões de anos, referente ao Período da Glaciação e a história do parque. Algumas estão inelegíveis e apagadas; outras se encontram em condições de leitura, mas em estado ruim de conservação.

a "playground" - nota 4

Existe um "playground" de tamanho menor, próximo ao "Bosque Bucólico", com equipamentos de madeira e outro maior, próximo à lanchonete, com equipamentos de ferro, em boas condições de uso, apesar de mal conservados.

ㅁortaria - nota 5

a quadras de jogos - nota 0

ㅁ quiosques - nota 5 (Figura 30)

Há oito quiosques redondos com uma mesa e quatro bancos cada.

ㄴ telefone público - nota 5

$\quad$ vegetação nativa implantada (espécies arbóreas isoladas) - nota 5

- vegetação nativa remanescente (fragmento florestal) - nota 0

A água que abastece o parque vem do Serviço Autônomo de Água e Esgoto de Itu - SAAE.

Todos os diferentes locais existentes dentro do Parque do Varvito são denominados por termos relacionados à Geologia e aos períodos geológicos remotos. $\mathrm{Na}$ portaria, existe um painel que organiza a visita aos principais pontos de interesse histórico, geológico e turístico do parque, assinalados em planta. Há um roteiro a ser seguido, indicado por números das paradas, para um melhor aproveitamento da visita. 
O Parque está sob responsabilidade da Secretaria de Turismo, que possui uma equipe de guias para turismo interno. O passeio custa $\mathrm{R} \$ 70,00$, em período integral e $\mathrm{R} \$ 50,00$ em meio período, sendo gratuito para entidades carentes.

A Prefeitura tem projetos para criação de um "site", que ainda não se encontra instalado. Serão criados também, segundo o administrador, "folders" estudantis sobre a história e a geologia do Parque do Varvito.

O acesso ao local pode ser feito, por carro, do centro da cidade de Itu ("Praça do Orelhão") pela Avenida Dr. Graciano Geribello, ou pela Rodovia do Açúcar, aproximadamente a $93 \mathrm{~km}$ da capital paulista. Desta rodovia, há placas indicativas que sinalizam e indicam o "Parque do Varvito". Por ônibus, o acesso é feito através do circular 11, que parte da Rodoviária de Itu.

O "site" do Município de Itu traz o Parque do Varvito como um dos atrativos turísticos da cidade, destacando sua história e algumas fotografias locais. Há um "folder", sem data de elaboração, que o divulga como ponto turístico do Município e destaca seus pontos mais importantes de visitação.

Arquivos da Prefeitura Municipal de Itu trazem o depoimento do Prefeito Lázaro José Punti, responsável pela construção do Parque do Varvito, atestando o investimento de R\$ 400 mil na infra-estrutura do Parque, não incluindo gastos com as desapropriações.

Existe um controle do número de visitantes, através de uma catraca, existente na entrada do Parque. Segundo o administrador, este número varia muito, pois há dias da semana em que recebe grupos de terceira idade e/ou crianças e há fins de semana chuvosos, em que recebe muito poucos visitantes. No ano de 2.005 , há registros de 6.080 visitantes em fevereiro, 3.774, em março, 7.722, em abril e 8.930 em maio, numa média de 6.626 visitas mensais.

O Parque do Varvito, segundo depoimentos existentes nos arquivos da Prefeitura Municipal de Itu foi construído para um público flutuante de 30 mil pessoas por dia. No dia da inauguração do Parque, estimou-se a participação de, aproximadamente, 2.500 pessoas. 


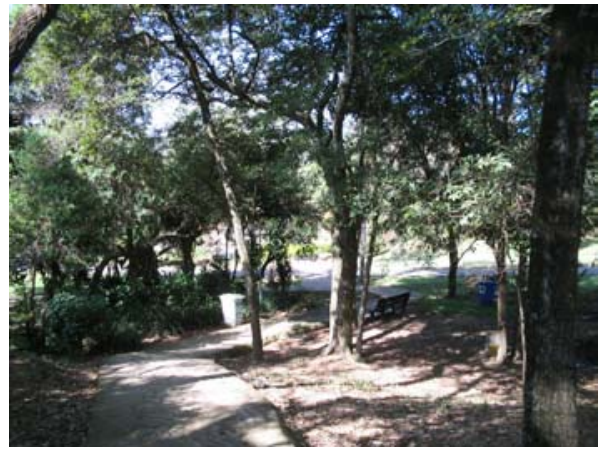

Figura 23 - Bosque Bucólico

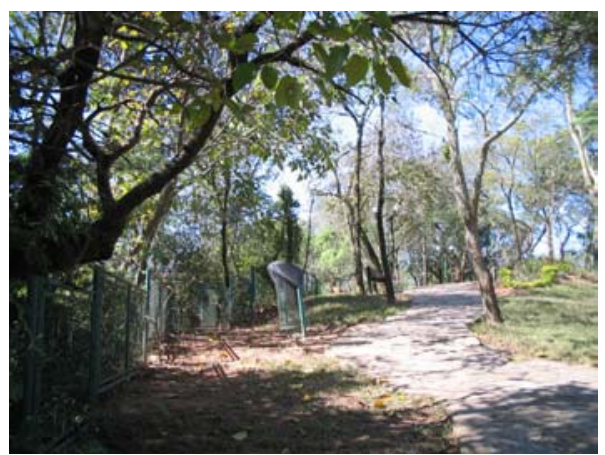

Figura 25 - Vereda dos Seixos

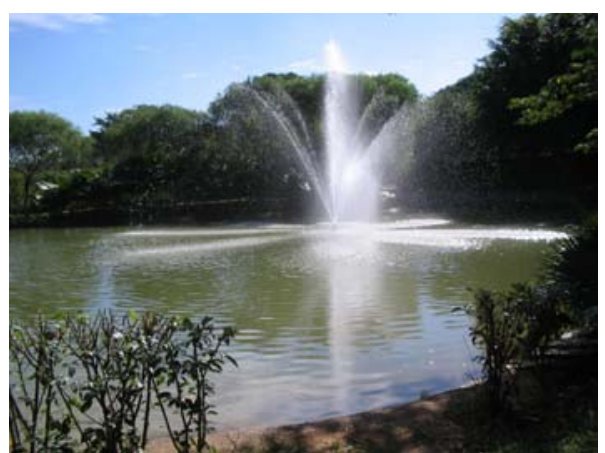

Figura 27 - Lago Jurássico

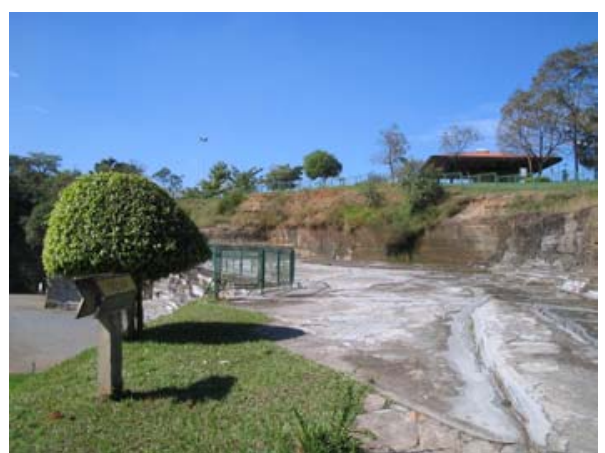

Figura 29 -Trilha dos Bentônicos

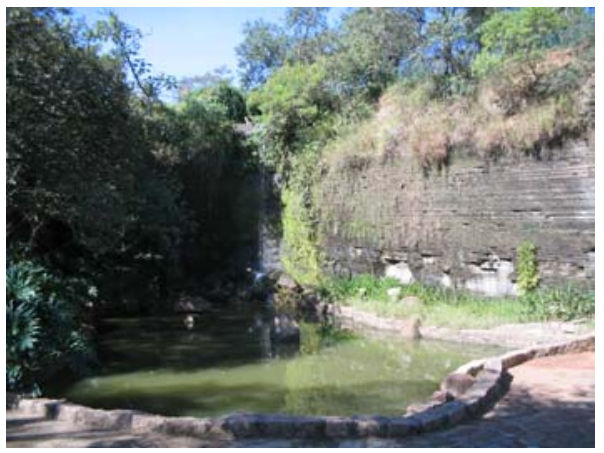

Figura 24 - Cascata do Antanho (fundo) e Lago dos Fósseis

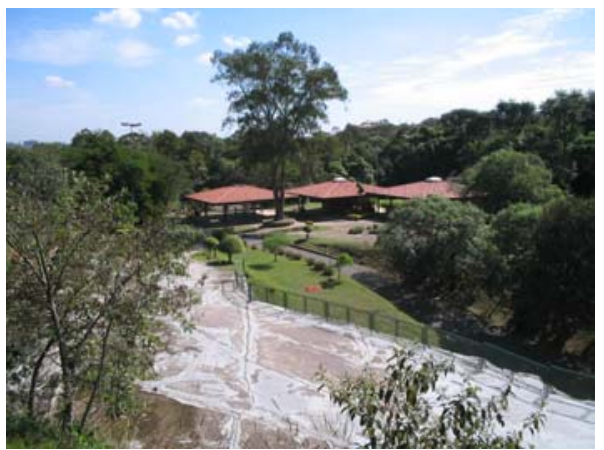

Figura 26 - Praça Cívica/Galpão Didático

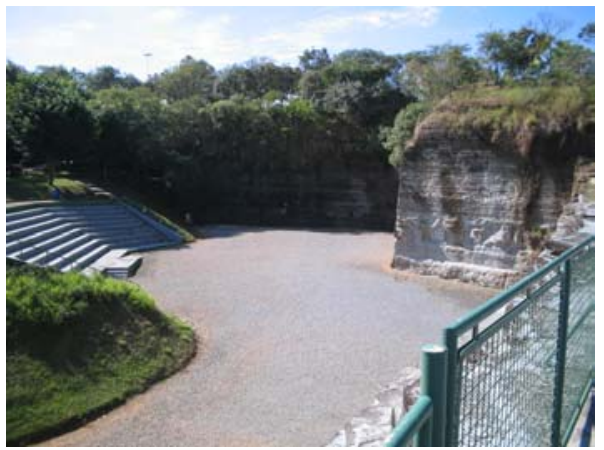

Figura 28 - Anfiteatro Gondvana

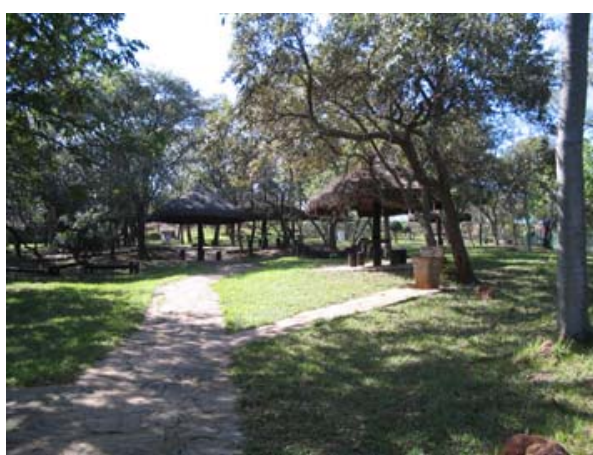

Figura 30 - Bosque dos Matacões 


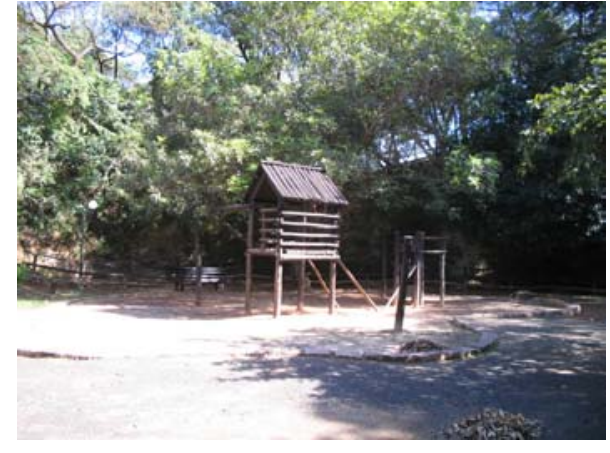

Figura 31 - "Playground"

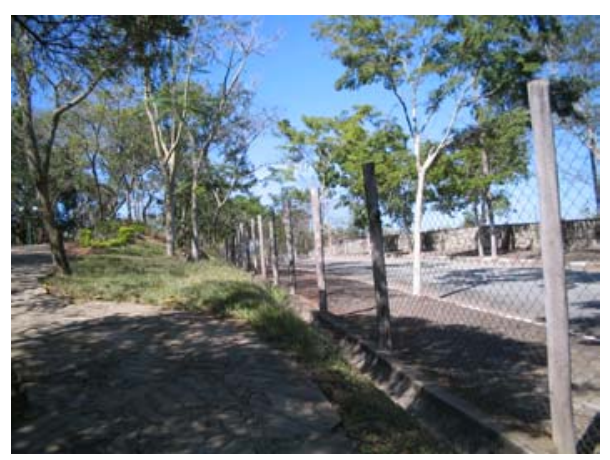

Figura 33 - Alambrado do Parque do Varvito

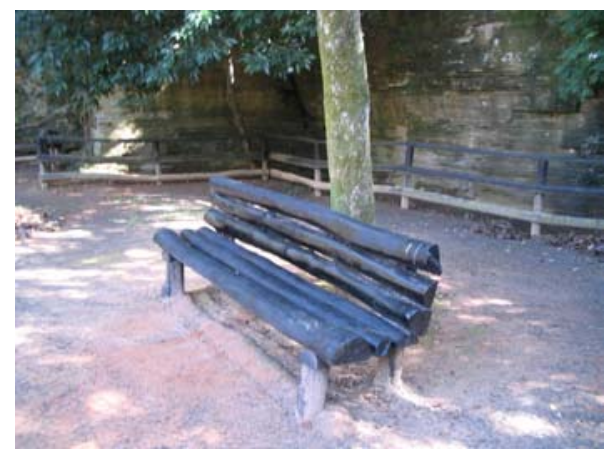

Figura 35 - Bancos do Parque do Varvito

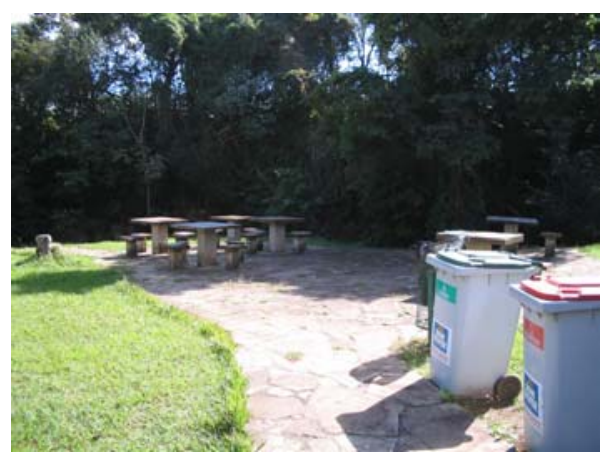

Figura 37 - Parque Cenozóico

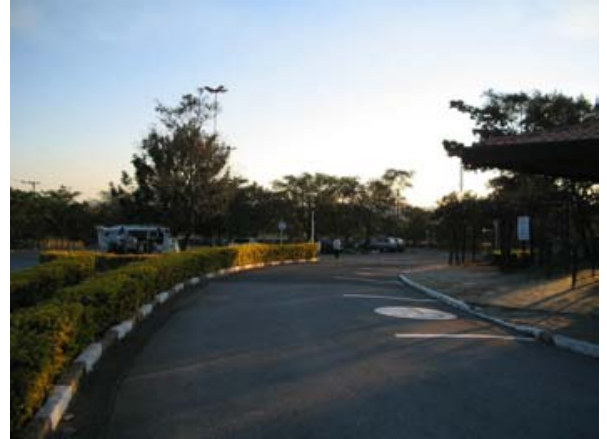

Figura 32 - Estacionamento

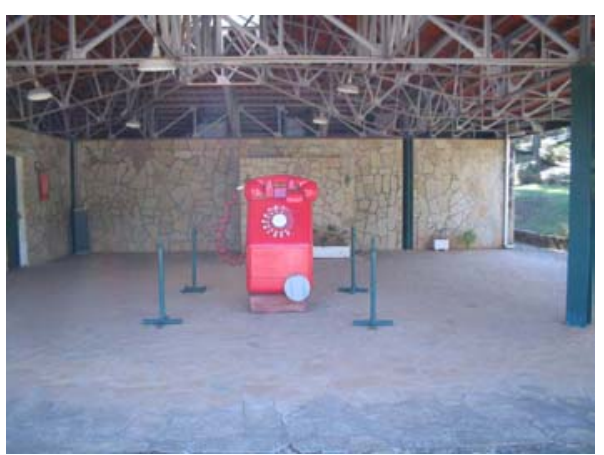

Figura 34 - Administração à esquerda, banheiros ao fundo e orelhão gigante

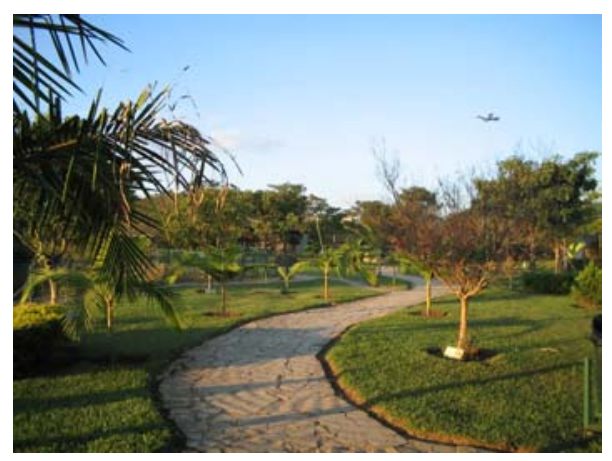

Figura 36 - Gramados

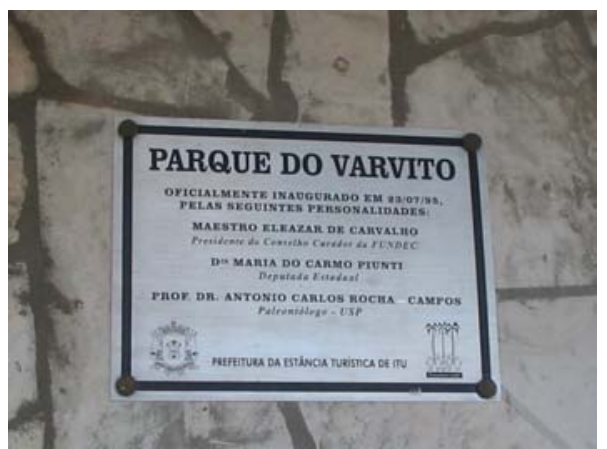

Figura 38 - Placa da entrada do Parque 


\subsection{Praça Dr. Ulisses Guimarães / Município de Campinas / SP}

\subsubsection{Aspectos locais da área de estudo}

\subsubsection{Características gerais da Praça Dr. Ulisses Guimarães}

A Praça Dr. Ulisses Guimarães localiza-se na região Centro-Sul do Município de Campinas (Figura 39), nas coordenadas UTM $285.680 \mathrm{~m}$ E e $7.467 .000 \mathrm{~m} \mathrm{~N}$ ou coordenadas geográficas $22^{\circ} 53^{\prime}$ Sul e $47^{\circ} 05^{\prime}$ Oeste, numa área de cerca de $130.000 \mathrm{~m}^{2}$, conforme a Prefeitura Municipal de Campinas (2005).

Inaugurada no dia 14 de julho de 1992, a Praça Dr. Ulisses Guimarães, também conhecida como antiga Pedreira do Chapadão, possui, além de uma praça central para shows, outras atrações como espelho d'água com cascata, canteiro e plantas, pista de "cooper" e ciclismo e o Memorial Ulisses Guimarães, com um grande busto em ferro do "Senhor Diretas", incrustado na rocha (Prefeitura Municipal de Campinas, 2005), resultante da extração de diabásio para brita, outrora realizada na área.

\subsubsection{Situação da área durante a atividade de extração do minério}

Não há registros históricos sobre a exploração do minério na área.

As únicas informações obtidas vieram do atual administrador do local, que confirma ter havido a extração do minério na área durante 72 anos e a paralisação das atividades há 37 anos.

Portanto, é possível afirmar que a extração mineral foi feita até 1968 e, durante 24 anos, a área permaneceu abandonada, sem nenhum tipo de reabilitação, até a data de inauguração da praça. O local foi recuperado como área de lazer pelo Departamento de Parques e Jardins (DPJ) da Prefeitura Municipal de Campinas.

A propriedade era de Octaviano Alves de Lima Filho e a extração do minério na área foi feita pelo mesmo. 


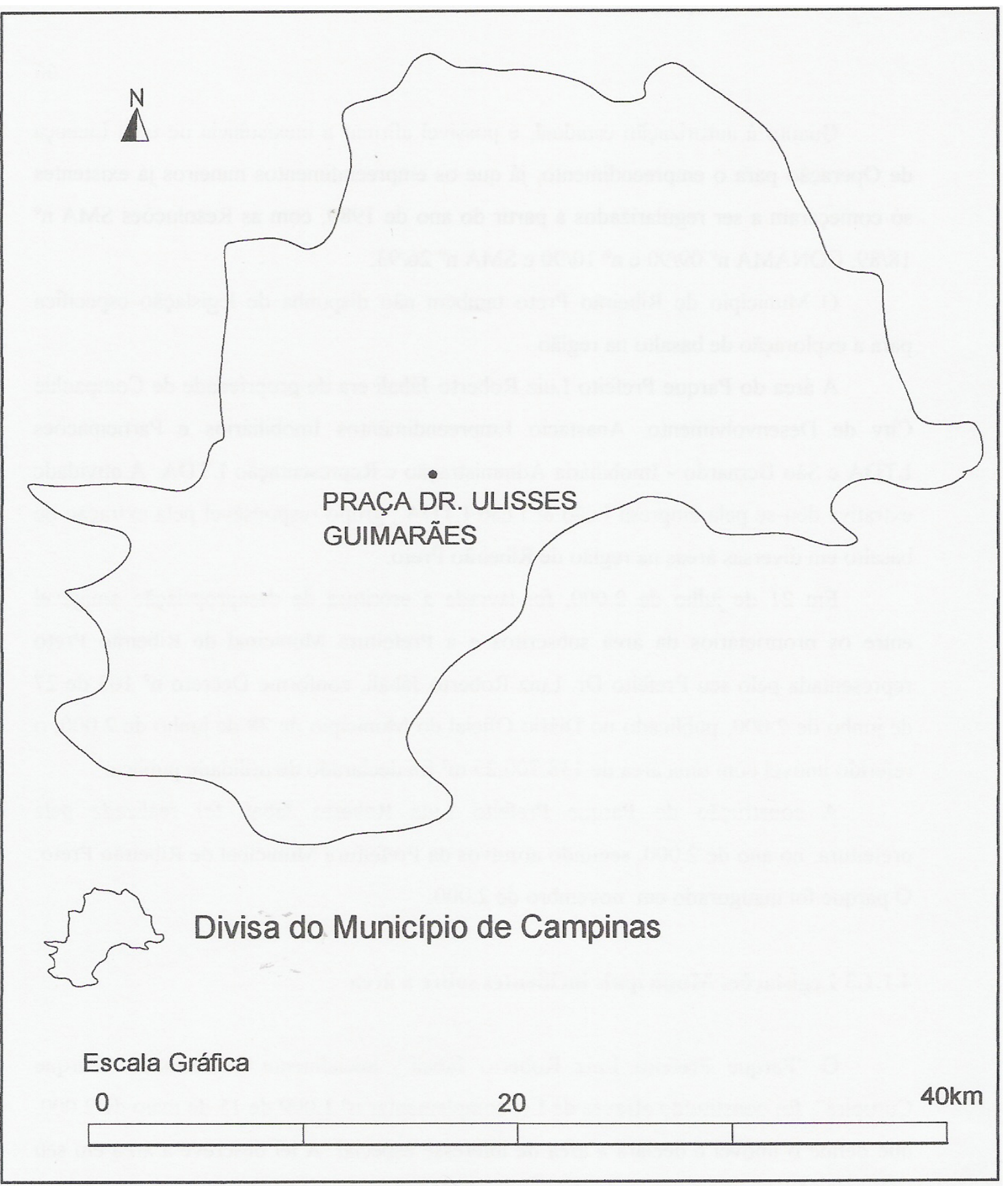

Fonte: Adaptado de Mapas Terra (2005)

Figura 39 - Localização da Praça Dr. Ulisses Guimarães no Município de Campinas 


\subsubsection{Legislações Municipais incidentes sobre a área}

Não foi possível obter, nos registros históricos municipais, dados sobre a desapropriação e a criação da área verde.

O Departamento Jurídico da Prefeitura de Campinas disponibilizou a Lei Municipal $\mathrm{n}^{\mathrm{0}} 7.352$ de 01/12/1992, publicada no Diário Oficial do Município de 02/12/1992, que, no seu artigo $2^{\circ}$, denomina "Praça Dr. Ulisses Guimarães", a Praça 3 do Jardim Chapadão - $2^{\mathrm{a}}$ gleba, contornada pela Avenida Marechal Rondon, Rua Dr. Alcides Carvalho, Rua 131, Rua Olívia Penteado, Rua Presidente João Goulart e divisa com propriedade de Octaviano Alves de Lima Filho ou sucessores até o encontro com a Avenida Marechal Rondon.

O Conselho de Defesa do Patrimônio Cultural de Campinas - CONDEPACC, pertencente à Secretaria Municipal de Cultura,Esporte e Turismo da Prefeitura Municipal de Campinas, abriu em 05 de abril de 2001, publicado no Diário Oficial do Município de 17 de abril de 2001, o processo $\mathrm{n}^{\circ}$ 002/2001, destinado ao estudo do tombamento da antiga Pedreira do Chapadão, denominada Praça Dr. Ulisses Guimarães e da Praça Octaviano Alves de Lima, situadas no Jardim Chapadão. O processo encontra-se em andamento.

\subsubsection{Situação atual da Praça Dr. Ulisses Guimarães}

A Praça Dr. Ulisses Guimarães localiza-se no entroncamento da Avenida Marechal Rondon com a Rua Dr. Alcides de Carvalho, $\mathrm{s} / \mathrm{n}^{\mathrm{o}}$ e dista, aproximadamente, 1.000 metros do centro da cidade. O horário de funcionamento é das 07:00 às 18:00 horas, diariamente.

O Memorial Ulisses Guimarães, localizado na Pedreira, consta de uma escultura composta por cerca de 2.000 chapas de aço recortadas e soldadas, formando o conjunto que pesa 2,5 toneladas com 13 metros de altura. Faz parte do conjunto, uma frase do Dr. Ulisses Guimarães, marcada no chão e na parede de pedra "Nós não viemos aqui para ter medo". A obra é do escultor Fábio Penteado (Prefeitura Municipal de Campinas, 2005). 
A área da Praça Dr. Ulisses Guimarães é cercada com alambrado (Figura 40) e possui vegetação introduzida (Figura 41 e 42), para a formação da área de lazer; não possui fragmento florestal remanescente de Floresta Estacional Semidecidual original.

Algumas espécies vegetais encontradas na área foram: amoreira (Morus nigra L.), palmeira jerivá (Syagrus romanzoffiana (Cham.) Glassm.), palmeira imperial (Roystonea borinquena O. F. Cook), mangueira (Mangifera indica L.), espatódea (Spathodea campanulata Beauv.), falsa murta (Murraya paniculata L.), eucalipto (Eucalyptus sp) e ligustro (Ligustrum japonicum Thumb.).

Não foram encontrados registros da fauna do local.

A manutenção da Praça Dr. Ulisses Guimarães é feita pela Prefeitura Municipal de Campinas. A área está sob responsabilidade de um administrador e mais três funcionários, incluindo um guarda, que não trabalha no período noturno, quando permanece fechada.

O local apresenta sinais de abandono quanto à manutenção, com papéis jogados no gramado (Figura 43). O Memorial Ulisses Guimarães exibe claros vestígios de falta de manutenção, com ferrugens e teias de aranha (Figura 44). Não há placas indicativas de perigo de desmoronamento em locais mais suscetíveis à queda de rochas, que, eventualmente, podem ocorrer, apesar do tempo de paralisação das atividades de lavra.

Os estados de conservação das benfeitorias existentes na Praça Dr. Ulisses Guimarães foram avaliados e conceituados, conforme parâmetros a seguir:

a administração - nota 0

alambrado - nota 5 (Figura 40)

ㅁ bancos - nota 4 (Figura 45)

$\quad$ banheiros - nota 3 (Figura 46)

O sanitário feminino apresenta cinco lavatórios e seis boxes com bacias sanitárias. O sanitário masculino apresenta cinco lavatórios, seis mictórios e seis boxes 
com bacias sanitárias. Não havia, no banheiro, os produtos de higiene necessários à utilização do local (papel higiênico, sabonete e papel toalha).

Não há, em ambos os banheiros, cabines adaptadas para deficientes físicos.

a bebedouros - nota 3

Existem oito bebedouros na área inteira, sendo que dois deles, localizados próximo ao quiosque, não funcionam.

a cachoeira (s) - nota 1

A cachoeira existente no local não funciona há dois anos.

duchas - nota 0

- equipamentos para ginástica - nota 0

a $\quad$ gramado - nota 3

- guarita - nota 4 (Figura 53)

Há duas guaritas na entrada da área.

$\quad$ lago (s) - nota 5 (Figura 47)

lanchonete (área de alimentação) - nota 0

ㄴ lixeiras - nota 0

A Praça Dr. Ulisses Guimarães possui somente um grande "container", para despejo de materiais recicláveis (Figura 48).

a monumentos - nota 3 
A Praça Dr. Ulisses Guimarães possui o Memorial Ulisses Guimarães, feito com chapas de aço recortadas e soldadas (Figura 49). Uma placa afixada abaixo do monumento apresenta sua data de inauguração, autor e autoridades presentes na inauguração (Figura 50).

$\quad$ palco para apresentações - nota 5 (Figura 51)

口 pátio de estacionamento - nota 0

- pistas para caminhadas - nota 0

Não foram identificadas pistas exclusivas para caminhadas de pedestres na área estudada.

$\quad$ pistas para bicicletas - nota 4 (Figura 52)

As pistas para passeios com bicicletas, não possuem marcas indicativas de passagem de ciclistas.

口 placas explicativas - nota 0

ㅁ "playground" - nota 4

a portaria - nota 0

$\quad$ quadras de jogos - nota 0

- quiosques - nota 4 (Figura 54)

Há um quiosque retangular, com duas mesas e quatro bancos cada.

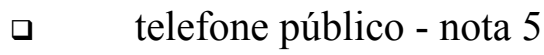


$\quad$ vegetação nativa implantada (espécies arbóreas isoladas) - nota 5 (Figura 42)

- vegetação nativa remanescente (fragmento florestal) - nota 0

A Sociedade de Abastecimento de Água e Saneamento S/A - SANASA, de Campinas, é responsável pelo abastecimento de água à Praça Dr. Ulisses Guimarães.

A área encontra-se sob a responsabilidade do Departamento de Cultura da Prefeitura do Município de Campinas.

A Prefeitura Municipal de Campinas distribui gratuita e mensalmente em bancas de jornal, a revista chamada "Ver e Ouvir", uma publicação da Secretaria de Cultura, Esportes e Turismo, que traz a Praça Dr. Ulisses Guimarães (Pedreira do Chapadão) como uma das áreas de lazer da cidade, na seção "Parques e Bosques", apesar do erro cometido no número telefônico da área.

O acesso à Praça Dr. Ulisses Guimarães pode ser feito, por carro, do centro da cidade de Campinas, através da Avenida Brasil, que possui placas indicativas para o bairro Chapadão. Por ônibus, a Linha Jardim Chapadão, circular que passa pelo centro e por outros pontos importantes do Município, leva à área estudada. Acessos mais rápidos e fáceis, como por exemplo, pela Avenida Radial Penido Burnier, conhecida por Suleste, que passa próximo à área, não fazem qualquer referência à mesma.

O "site" do Município de Campinas traz, com pequeno destaque, a Praça Dr. Ulisses Guimarães como uma área de lazer da cidade.

O número médio de visitantes, por dia, atestado pelo administrador do local, é de 90 pessoas, em média, de segunda a sexta-feira e de 1.000 pessoas nos dois dias do fimde-semana. Portanto, a média mensal de visitantes à Praça Dr. Ulisses Guimarães é de 6.000 pessoas. 


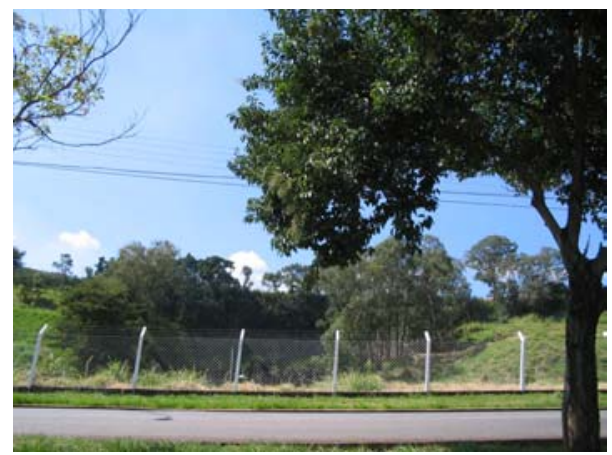

Figura 40 - Alambrado

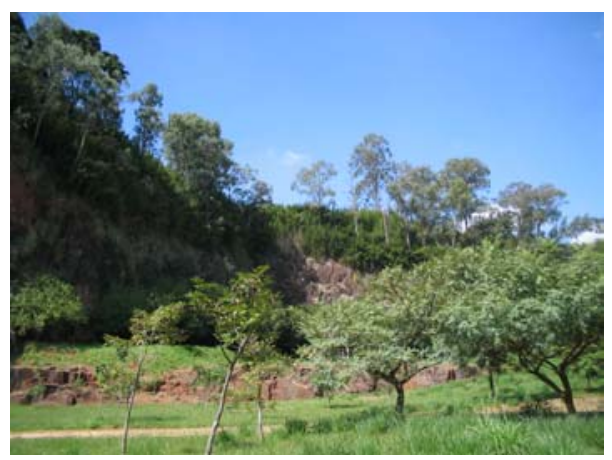

Figura 42 - Vegetação implantada

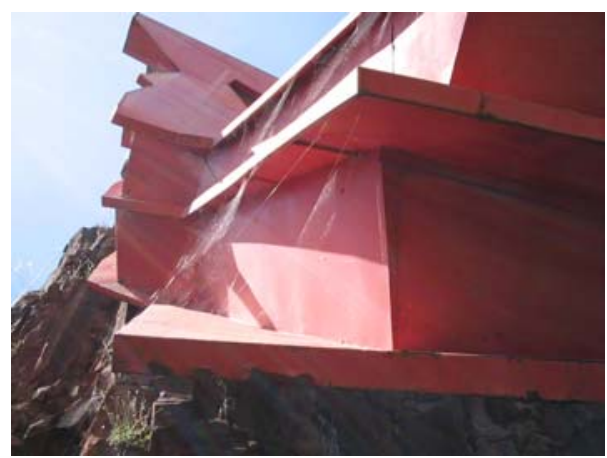

Figura 44 - Falta de manutenção do memorial

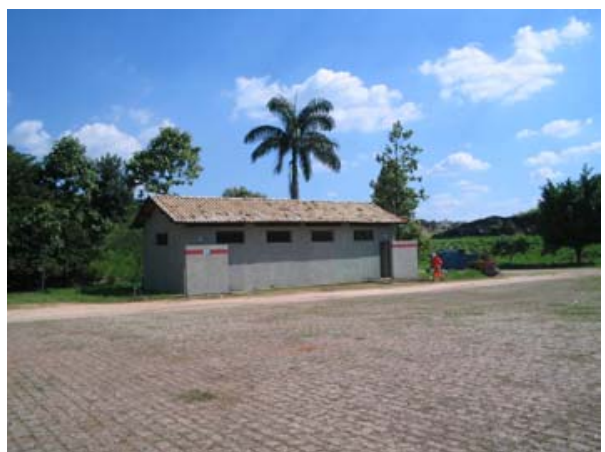

Figura 46 - Banheiro

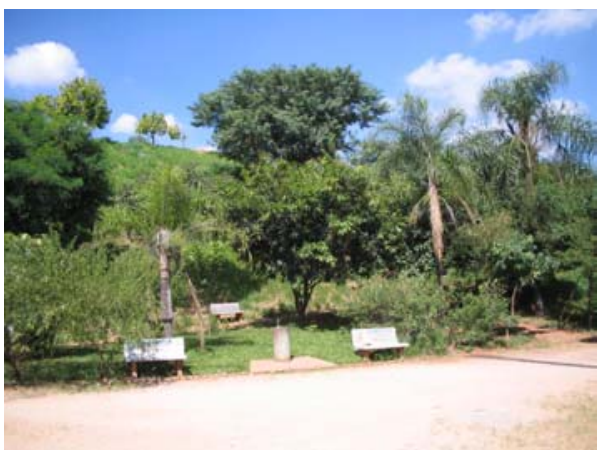

Figura 41 - Vegetação implantada

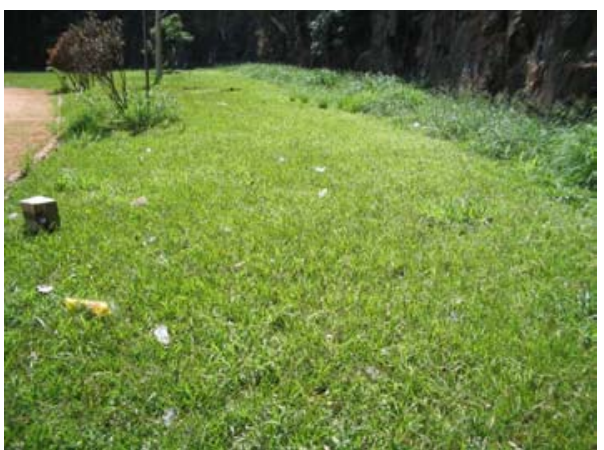

Figura 43 - Falta de manutenção do gramado

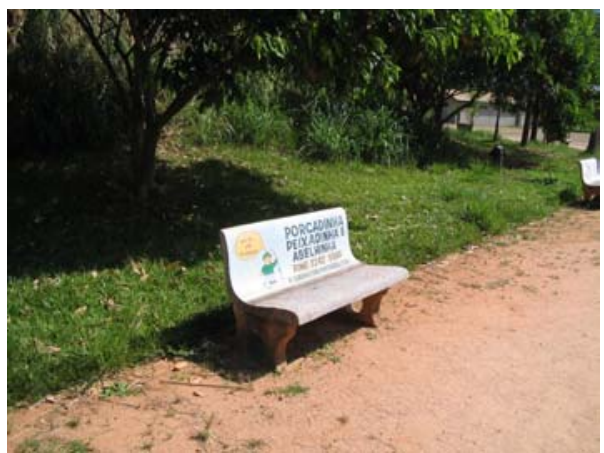

Figura 45 - Banco

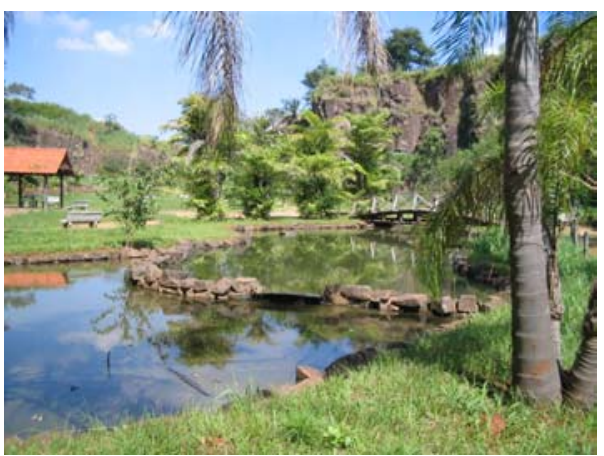

Figura 47 - Lago 


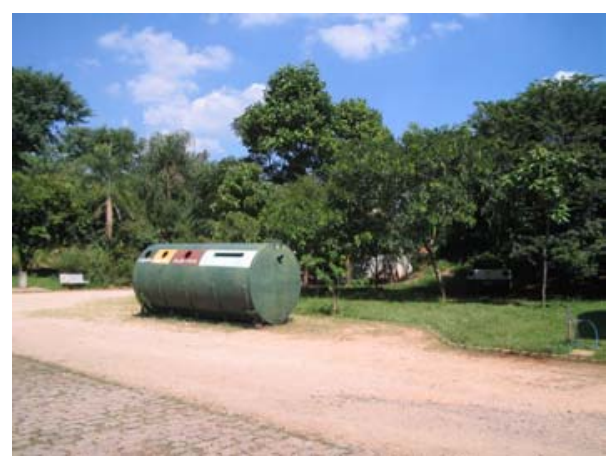

Figura 48 - Lixeira para materiais recicláveis

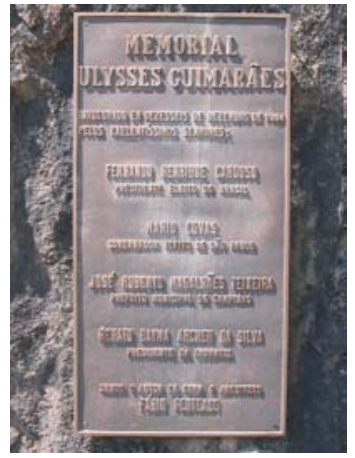

Figura 50 - Placa ao memorial

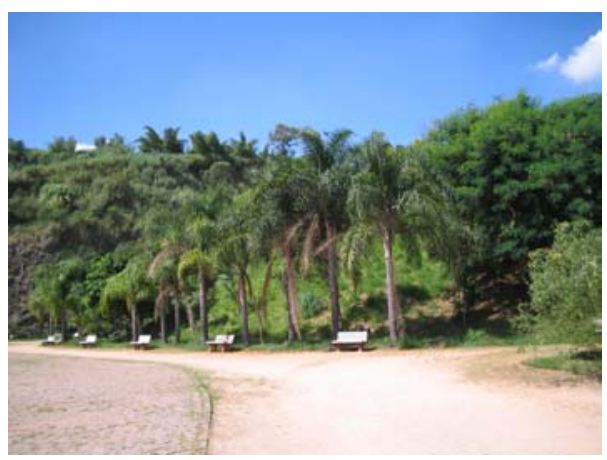

Figura 52 - Pista para ciclismo

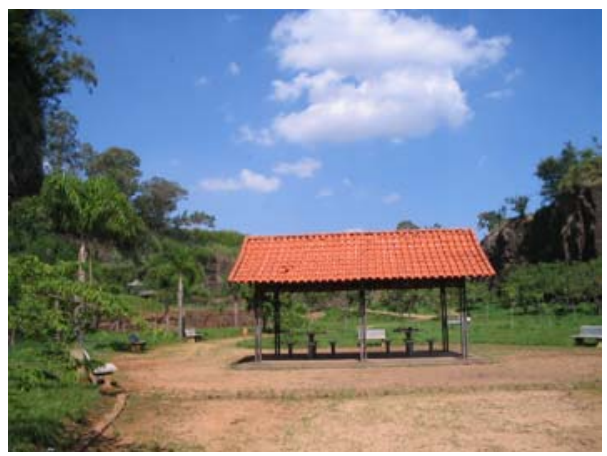

Figura 54 - Quiosque

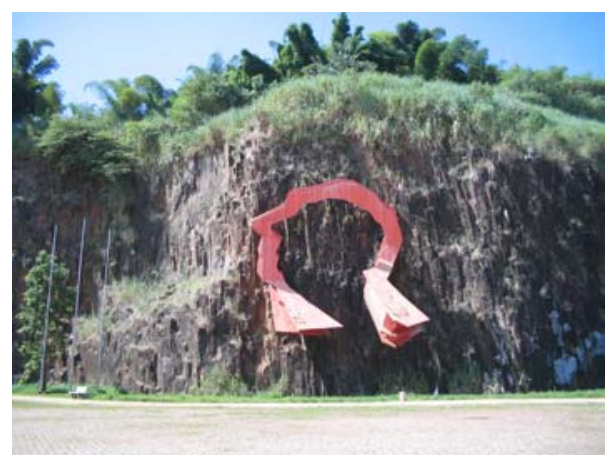

Figura 49 - Memorial Ulisses Guimarães

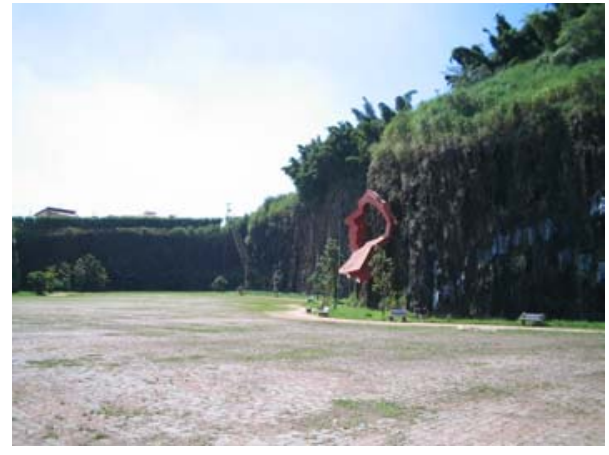

Figura 51 - Palco para apresentações

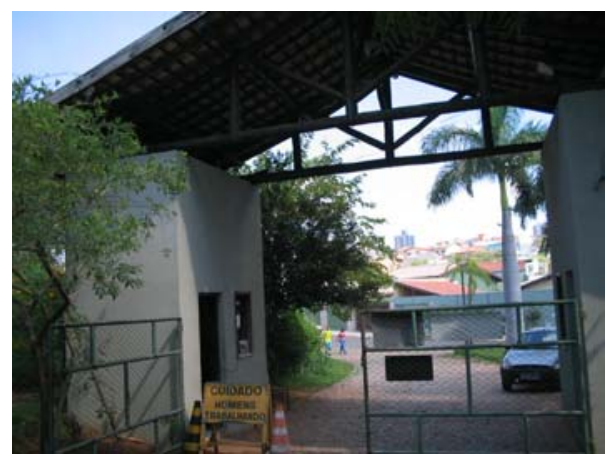

Figura 53 - Guaritas

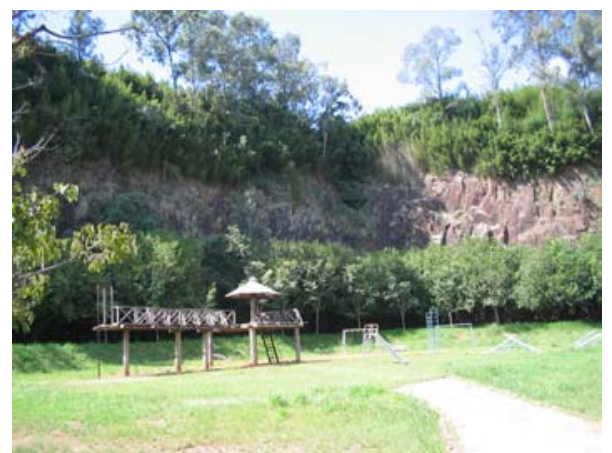

Figura 55 - "Playground" 
Os três locais de estudo localizam-se em pólos produtores de materiais aproveitados para construção civil no Estado de São Paulo (Ribeirão Preto, Campinas e Sorocaba), conforme atestado por Tanno \& Sintoni (2003).

Os sítios analisados estão muito próximos ao centro urbano das cidades, o que contribui para a diminuição do preço de transporte, e conseqüente, valor dos produtos para o consumidor final.

Todas as áreas degradadas pelas atividades minerárias, localizadas em áreas urbanas, ou em áreas rurais, conforme atestado nesse trabalho, devem ser recuperadas, restauradas, reabilitadas ou remediadas, conforme legislações federal, estadual e, se existir, municipal.

Apesar da prática e da tendência brasileiras pelo uso do termo recuperação, importado da legislação, os Parques Prefeito Luiz Roberto Jábali e Varvito e a Praça Dr. Ulisses Guimarães, pelas definições de Willians et al (1990) foram reabilitados, pois os sítios degradados retornaram a um estado biológico apropriado e ambientalmente favorável, visando a recreação e a valorização estético-ecológica do local, sem regressarem ao uso do solo original.

Porém, especificamente para essa dissertação, o conceito definido como o mais apropriado às situações apresentadas foi "redestinação", apoiado em Rodrigues \& Gandolfi (2001), pois houve a conversão do ecossistema degradado "mineração", ao ecossistema estável, diferente do original local, "áreas verdes públicas".

O Município de Ribeirão Preto possui o Código do Meio Ambiente que trata da proteção ambiental e da mineração, responsabilizando o minerador pela "recuperação" da área degradada, reforçando, assim, as legislações federais (Lei $n^{0}$ 6.938/81, que dispõe sobre a Política Nacional do Meio Ambiente, a Constituição da República Federativa do Brasil de 1988, o Decreto Federal 97.632/89, que estabelece a apresentação do PRAD, para os empreendimentos já existentes) e estaduais (Resolução SMA n ${ }^{0}$ 18/89, que regulamenta e determina a apresentação de plano de recuperação dos empreendimentos minerários em processo de licenciamento, estabelecendo um roteiro básico para a elaboração do PRAD e a Constituição do Estado de São Paulo, de 1989), incidentes sobre o empreendimento. 
O Município, com a ampla gama de áreas atualmente existentes, cuja degradação foi resultante de extração de basalto para brita, possui uma preocupação particular com o assunto e inaugurou, em dezembro de 2004, outro parque municipal em área outrora minerada (Parque Municipal dr. Luiz Carlos Raya).

Outros usos para o solo foram observados no Município, com o intuito de recuperar e redestinar áreas degradadas pelas minerações de basalto para brita: o Santuário Sete Capelas, localizado no centro do Município; o Condomínio Residencial Jardim das Pedras, de classe média baixa, criado em 1986, com uma população moradora atual de 18.000 habitantes; a Usina de asfalto da Prefeitura Municipal de Ribeirão Preto, localizada próxima à Universidade de São Paulo, em terreno da Prefeitura Municipal e da universidade.

O Município de Itu legisla sobre uma Área de Proteção Ambiental denominada Estrada Parque, regulamentando as atividades próximas a este local. Por outro lado, não foram disponibilizadas leis locais, que regulamentem e obriguem a recuperação de áreas degradadas existentes no Município.

O Município de Campinas não possui legislação municipal que obriga o empreendedor degradador a recuperar ou reabilitar a área. O Município conta, atualmente, com as obrigações impostas pelas legislações estaduais e federais. A Secretaria de Planejamento e Meio Ambiente está em fase de elaboração do Código Ambiental, com previsão para entrar em vigor até o final de 2005. Há arquivos municipais de uma pedreira abandonada no local denominado "Pedra Brasil", no Jardim Garcia, de propriedade particular, sem indícios ou projetos de recuperação.

As áreas estudadas, pela história de extração, deveriam ter licenciamento regularizado somente no DNPM, já que a legislação estadual é muito recente e não repercute sobre tais áreas. A área de Campinas foi minerada sem qualquer documentação do DNPM. Já as áreas de Ribeirão Preto e Itu tiveram seus funcionamentos devidamente autorizados por este Departamento.

A partir das definições relatadas dos termos "parques" e "praças", é possível contestar a utilização da expressão "praça" para a área verde estudada em Campinas, já que possui função ecológica, estética e de lazer (Lima et al, 1994), dimensão 
significativa e predomínio de elementos naturais (Kliass, 1993) e é destinado à recreação de massa, com estrutura morfológica auto-suficiente, sem influência com nenhuma estrutura construída em seu entorno (Macedo \& Sarata, 2003).

A manutenção do Parque Prefeito Luiz Roberto Jábali, em Ribeirão Preto, pode ser considerada como altamente positiva, conforme observado nas visitas de campo. A população cobra pelos bons tratos ao local e exige, dos funcionários, a limpeza e a manutenção dos equipamentos presentes. Assim, a área acaba funcionando e pode ser considerada um exemplo de área verde de sucesso.

O Parque do Varvito tem limpeza geral em bom estado, porém alguns equipamentos e algumas placas explicativas, envelhecidas com o tempo, não foram reformados, prejudicando a avaliação da manutenção geral; pode ser considerada, pelos parâmetros avaliados, uma área intermediária em manutenção.

A Praça Dr. Ulisses Guimarães encontra-se totalmente abandonada pela Prefeitura Municipal, sem funcionários para faxina geral. A divulgação da área mal existe no "site" da Prefeitura, sendo destacada muito mais por seus eventos culturais, do que por uma área de lazer, destinada à visita rotineira da população.

O Parque Prefeito Luiz Roberto Jábali possui quatro bebedouros, quantidade considerada insuficiente para o tamanho do parque. Já sua quantidade de lixeiras impede que o visitante, onde quer que esteja, não tenha um local para despejo de lixos, algo importantíssimo para induzir à educação da população.

O Parque do Varvito poderia ter uma maior quantidade de cestos de lixo, para impedir que dejetos sejam atirados em qualquer lugar.

A Praça Dr. Ulisses Guimarães, sem nenhuma lixeira na área inteira, dificulta qualquer iniciativa relacionada a trabalhos de educação ambiental no local e a conservação da área verde.

As três áreas pesquisadas foram desflorestadas para o desenvolvimento da atividade minerária e somente o Parque Prefeito Luiz Roberto Jábali, possui um fragmento florestal remanescente da Floresta Estacional Semidecidual original, resultante da área de Reserva Florestal Obrigatória, preservada pelo proprietário. Este parque possui, também, plano de manejo da vegetação natural e implantada, com o 
intuito de administrar os plantios realizados destinados à recomposição florestal, controlar as espécies invasoras e manejar a área gramada. As espécies vegetais plantadas são espécies nativas da Floresta Estacional Semidecidual.

O Parque do Varvito apresenta espécies vegetais de diversas formações vegetais paulistas: Cerrado, Floresta Ombrófila Densa, Floresta Semidecidual, além de espécies exóticas. Tal fato leva a uma idéia de falta de planejamento nas espécies vegetais implantadas no parque e falta de interesse na manutenção de um remanescente florestal nativo local e regional.

A Praça Dr. Ulisses Guimarães confirma os estudos de Santos \& Kinoshita (2003), realizados nos bosques do Município de Campinas, que evidenciam a fragmentação dos remanescentes florestais, cada vez mais diferentes entre si, apresentando mistura de espécies nativas com espécies exóticas e pouca preocupação em preservação da história vegetacional local e regional.

A identificação das espécies vegetais, através de plaqueamento, no Parque do Varvito, não ocorre em nenhuma outra área estudada e foi avaliada como um instrumento interessantíssimo para as atividades de cunho ambiental e cultural ocorridas no local, despertando curiosidades pela ecologia em crianças, jovens e adultos.

A reivindicação da comunidade pelo cuidado aos espaços livres, bem como a exigência por sua manutenção, são imprescindíveis para que as áreas tornem-se locais de lazer, realmente usufruídos pela população, e não somente, áreas verdes que aumentam quantitativamente, o índice de áreas verdes do Município.

Os três Municípios dispõem de transportes públicos para as áreas verdes, o que facilita o acesso da população de baixa renda. Os pátios de estacionamento do Parque Prefeito Luiz Roberto Jábali e do Parque do Varvito facilitam a visita de pessoas de média e alta renda, fato que não ocorre na Praça Dr. Ulisses Guimarães, já que as únicas maneiras de parada de automóveis são nas ruas próximas ao local..

A divulgação das áreas verdes com "folders", propagandas em veículos de comunicação e "sites" informam melhor a população sobre os locais, despertando maiores interessados pela visita. 
O conhecimento da história local é imprescindível para levantar curiosidades na população e pode gerar estudos multidisciplinares sobre as áreas verdes.

A relação, em porcentagem, entre a população residente nos respectivos Municípios e a visitação às áreas é de 9,5\% para Ribeirão Preto, 5\% para Itu e 0,6\% para Campinas. Isso demonstra a aceitação popular pelas áreas, principalmente às bem cuidadas, e sua funcionalidade como espaço de lazer e de recreação para a população local. 


\section{CONCLUSÃO}

1. O Parque Prefeito Luiz Roberto Jábali, localizado em Ribeirão Preto, foi considerado, dentre as três áreas de estudo, o sítio, cujas benfeitorias analisadas, encontram-se em melhor estado de conservação, já que $70 \%$ delas obtiveram nota 5 (cinco), 19\% obtiveram nota 4 (quatro) e 11\% obtiveram notas abaixo de 4 (quatro). A área possui um fragmento florestal remanescente da Floresta Estacional Semidecidual original e um plano de manejo da vegetação natural e implantada, com o intuito de administrar os plantios realizados destinados à recomposição florestal, controlar as espécies invasoras e manejar a área gramada. As espécies vegetais plantadas são espécies nativas da Floresta Estacional Semidecidual. O Município de Ribeirão Preto possui o Código do Meio Ambiente, que trata da proteção ambiental e da mineração, responsabilizando o minerador pela "recuperação" da área degradada, reforçando, assim, as legislações federais e estaduais, incidentes sobre o empreendimento. A extração do basalto realizada na área do Parque Prefeito Luiz Roberto Jábali foi devidamente autorizada pelos órgãos públicos competentes. A manutenção local é feita pela empresa de economia mista, CODERP, conveniada com a Prefeitura, para estruturação e manutenção dos parques municipais. O parque apresenta-se muito bem cuidado, pois não se vê papéis jogados no chão e sinais de abandono quanto à manutenção. A cobrança da população pelos bons tratos ao local auxilia na boa conservação da área verde. O Município de Ribeirão Preto dispõe de três linhas de ônibus municipais, que permitem o acesso da população de baixa renda ao parque e o pátio de estacionamento da área facilita a visita de pessoas de média e alta renda. A área verde é bem divulgada no "site" do Município e por "folders", que destacam as principais características do 
local. O Parque Prefeito Luiz Roberto Jábali recebe por volta de 48.000 visitas mensais, o que representa, 9,5\% da população do Município de Ribeirão Preto.

2. O Parque do Varvito, localizado em Itu, foi considerado, dentre as três áreas de estudo, o sítio, cujas benfeitorias analisadas, encontram-se num estágio intermediário de conservação, já que $65 \%$ delas obtiveram nota 5 (cinco), $4 \%$ obtiveram nota 4 (quatro) e $31 \%$ obtiveram notas abaixo de 4 (quatro). A área não possui fragmento florestal remanescente de vegetação original da Mata Atlântica, somente espécies vegetais nativas e exóticas isoladas, identificadas por placas com seus nomes vulgar e científico. Não foram disponibilizadas, leis ituanas, que regulamentem e obriguem a recuperação de áreas degradadas existentes no Município. A extração do varvito realizada na área foi devidamente licenciada pelos órgãos públicos competentes. A manutenção do Parque do Varvito é feita pela Prefeitura Municipal de Itu. O parque apresenta-se bem cuidado, quanto à faxina geral. O Município de Itu dispõe de uma linha de ônibus municipal, que permite o acesso da população de baixa renda ao parque e o pátio de estacionamento local facilita a visita de pessoas de média e alta renda e de turistas vindo de cidades próximas. O "site” do Município de Itu traz o Parque do Varvito como um dos atrativos turísticos da cidade, destacando sua história e algumas fotografias locais. Há um "folder", sem data de elaboração, que o divulga como ponto turístico do Município e destaca seus pontos mais importantes de visitação. O Parque do Varvito recebe por volta de 6.626 visitas mensais, o que representa, 5\% da população do Município de Itu.

3. A Praça Dr. Ulisses Guimarães, localizada em Campinas, foi considerada, dentre as três áreas de estudo, o sítio, cujas benfeitorias analisadas, encontram-se em pior estado de conservação, já que 19\% delas obtiveram nota 5 (cinco), 19\% obtiveram nota 4 (quatro) e 62\% obtiveram notas abaixo de 4 (quatro). A área não possui fragmento florestal remanescente de Floresta Estacional Semidecidual original, somente espécies vegetais isoladas nativas e exóticas. O Município de Campinas não possui legislação municipal, que obriga a recuperação e a reabilitação de áreas degradadas pelos respectivos responsáveis. O Município conta, atualmente, com as obrigações impostas 
pelas legislações estaduais e federais. A área da Praça Dr. Ulisses Guimarães foi minerada sem qualquer licenciamento do órgão público competente. A manutenção da Praça Dr. Ulisses Guimarães é feita pela Prefeitura Municipal de Campinas. O local apresenta sinais de abandono, quanto à faxina geral. O Município de Campinas dispõe de uma linha de ônibus municipal, que permite o acesso da população de baixa renda à praça, porém, a falta de um pátio de estacionamento, dificulta a visita de pessoas de média e alta renda. O "site" do Município de Campinas traz, com pequeno destaque, a Praça Dr. Ulisses Guimarães como uma área de lazer da cidade. A Praça Dr. Ulisses Guimarães recebe por volta de 6.000 visitas mensais, o que representa, $0,6 \%$ da população do Município de Campinas.

\subsection{Considerações gerais}

A redestinação de áreas degradadas pela mineração para áreas verdes públicas é uma boa forma de reutilização do local, pois cumpre a legislação vigente e repara o dano causado pela atividade minerária ao meio ambiente, retornando a área para usufruto da população, outrora prejudicada pelo empreendimento instalado, além de buscar uma situação de normalidade e estabilidade ao sítio deteriorado. Porém, somente a maneira como é conduzida a sua manutenção indica se o local presta-se à finalidade das áreas verdes urbanas: oferecer à população dos grandes centros urbanos, oportunidades de lazer, recreação, bem-estar, aumentando, assim, sua qualidade de vida e seu contato com a natureza.

A manutenção das áreas verdes municipais pode variar de positiva para negativa, de acordo com a gestão pública vigente. No trabalho realizado, isso foi claramente comprovado, através do contato feito com as Prefeituras locais. Em Ribeirão Preto, existe uma Secretaria de Planejamento e Gestão Ambiental instalada, responsável pelas áreas verdes municipais, que apresenta organização com relação à documentação da área estudada, o que, provavelmente refletiu na manutenção do local estudado. Em Itu, a Secretaria de Turismo responde pelo Parque do Varvito, mas é a Secretaria da Cultura que possui os dados históricos da área verde. A Prefeitura de Campinas possui o 
Departamento de Parques e Jardins, responsável pelas áreas verdes do Município. Porém, o local de estudo, pertence à Secretaria da Cultura, fato que gera uma certa confusão, entre os próprios funcionários públicos municipais. O Departamento Jurídico desconhece leis incidentes sobre a área, relativas à desapropriação do local ou a criação da área verde. O CONDEPACC detém um processo em andamento, paralisado, sobre o tombamento da Pedreira do Chapadão, como é popularmente conhecida, a Praça Dr. Ulisses Guimarães. Esses fatos, coincidem e refletem sobre a área em estudo, considerada completamente abandonada, quanto à sua manutenção, cujas informações e história só foram possíveis, devido à existência de um administrador antigo no local, que tem, pela área, afetividade e emoção.

O Parque Prefeito Luiz Roberto Jábali cumpre as funções primordiais de uma área verde, além de contribuir para o aumento do índice de áreas verdes do Município de Ribeirão Preto. O Parque do Varvito apresenta algumas benfeitorias mal conservadas, porém cumpre suas funções culturais e paisagísticas, elevando, também, o índice de áreas verdes do Município. A Praça Dr. Ulisses Guimarães, embora eleve o índice de áreas verdes do Município, não atinge os objetivos básicos de uma área verde municipal.

A manutenção das áreas verdes públicas é realmente eficaz e positiva, quando a população cobra os funcionários e o órgão público municipal e reivindica os cuidados à área, como limpeza geral, preservação de equipamentos e conservação da infra-estrutura.

Atualmente, as extrações de minerais têm sido alvo de solicitações de instalação e funcionamento aos órgãos públicos estaduais, federais e municipais. As atividades básicas no planejamento da recuperação, que envolvem, definição dos objetivos, estabelecimento do uso futuro da área, elaboração de um plano de recuperação e compromisso de recuperação da área pelo empreendedor, são levados em consideração, tanto na elaboração dos Relatórios Ambientais e Planos de Recuperação de Áreas Degradadas, quanto na sua análise para licenciamento.

Porém, o uso futuro da área pode ser modificado, pois muitos projetos são elaborados, estimando uma vida útil longa ao empreendimento. Este fato pode causar mudanças nos interesses do proprietário da área, da população local e regional e dos órgãos públicos. Isto deve ser observado, analisado e acompanhado, durante toda a 
operação do empreendimento e oportunamente modificado, sempre levando em conta os interesses da população e a legislação vigente.

A reabilitação de áreas degradadas pela mineração em áreas verdes públicas é uma das maneiras mais eficientes de aumentar o índice de áreas verdes das grandes cidades, ampliar suas áreas de lazer e, conseqüentemente, diminuir seus índices de criminalidade, proporcionando à população, maiores atrativos paisagísticos e ambientais, ampliando seus interesses pela natureza e sua qualidade de vida.

A legislação referente às áreas degradadas ainda é muito deficiente e pouco respeitada pelos infratores. O cumprimento das leis pelo infrator e a plena implementação do Plano de Recuperação de Áreas Degradadas pelos empreendedores devem ser rigorosamente fiscalizados por todos os órgãos públicos (federais, estaduais e municipais) e pela população.

A existência de legislação municipal, principalmente nas grandes cidades e a fiscalização para seu cumprimento são essenciais para evitar o abandono de áreas utilizadas por empreendimentos minerários e industriais. 
ANEXOS 


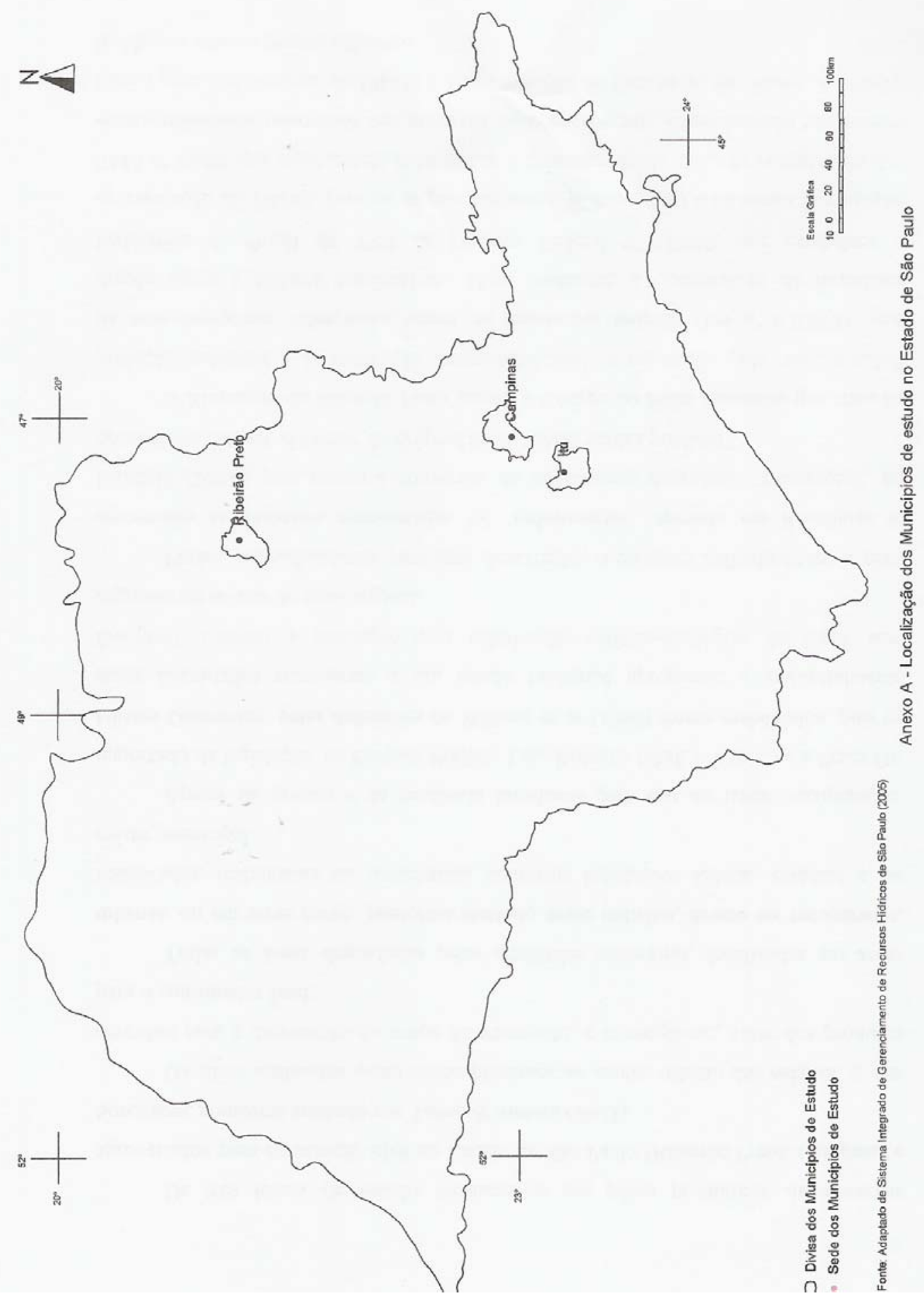




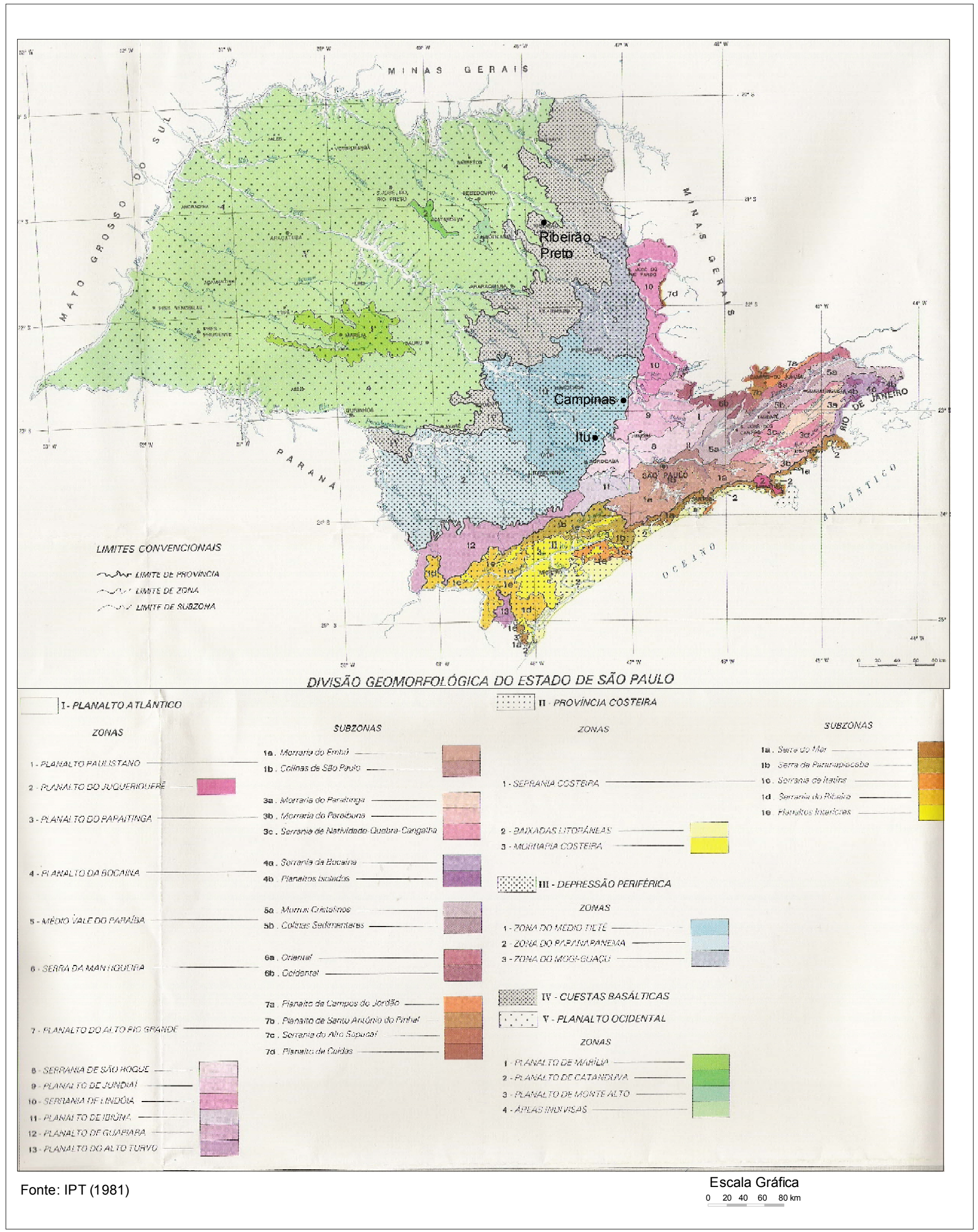




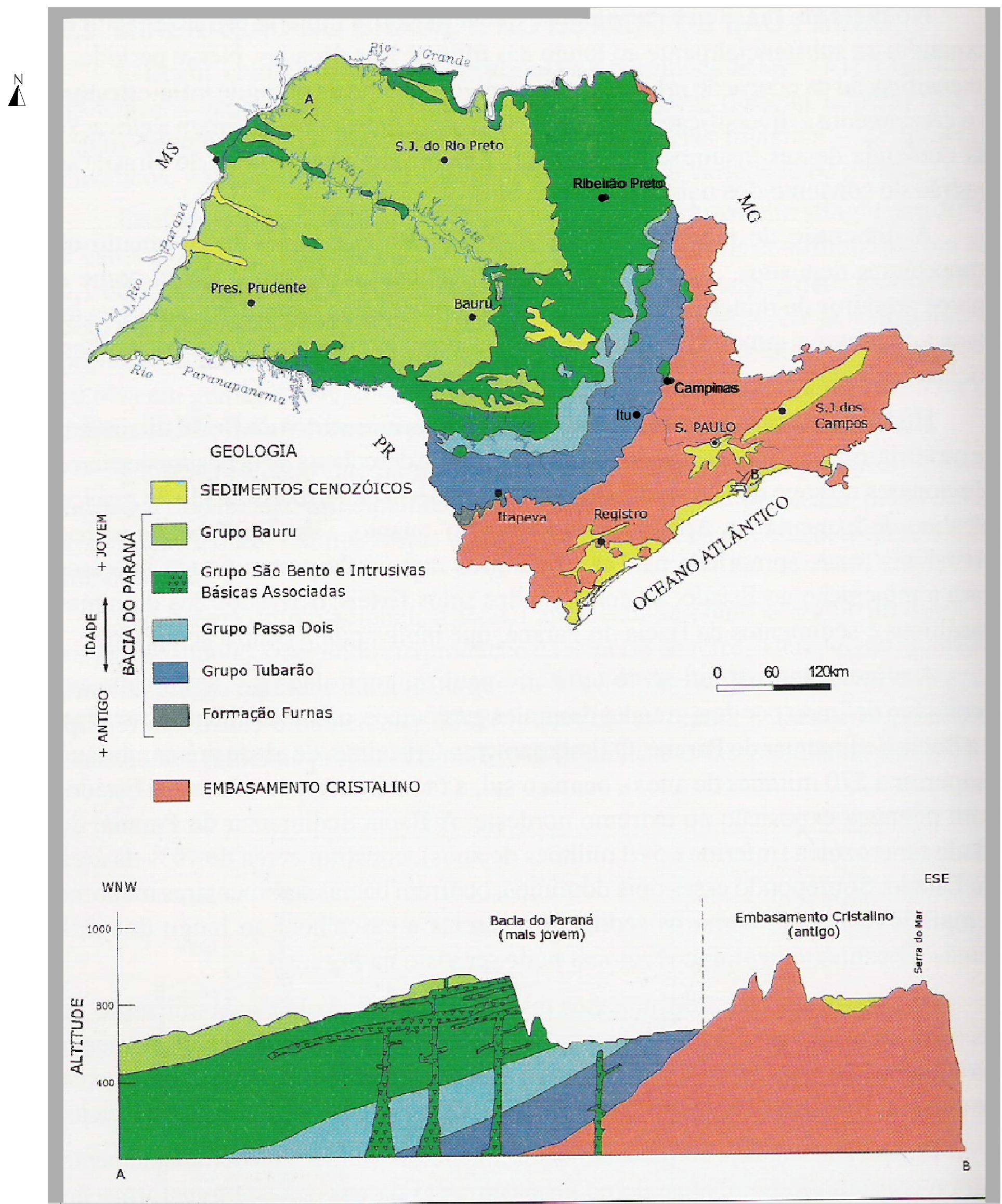

Fonte: Tanno \& Sintoni (2003) 


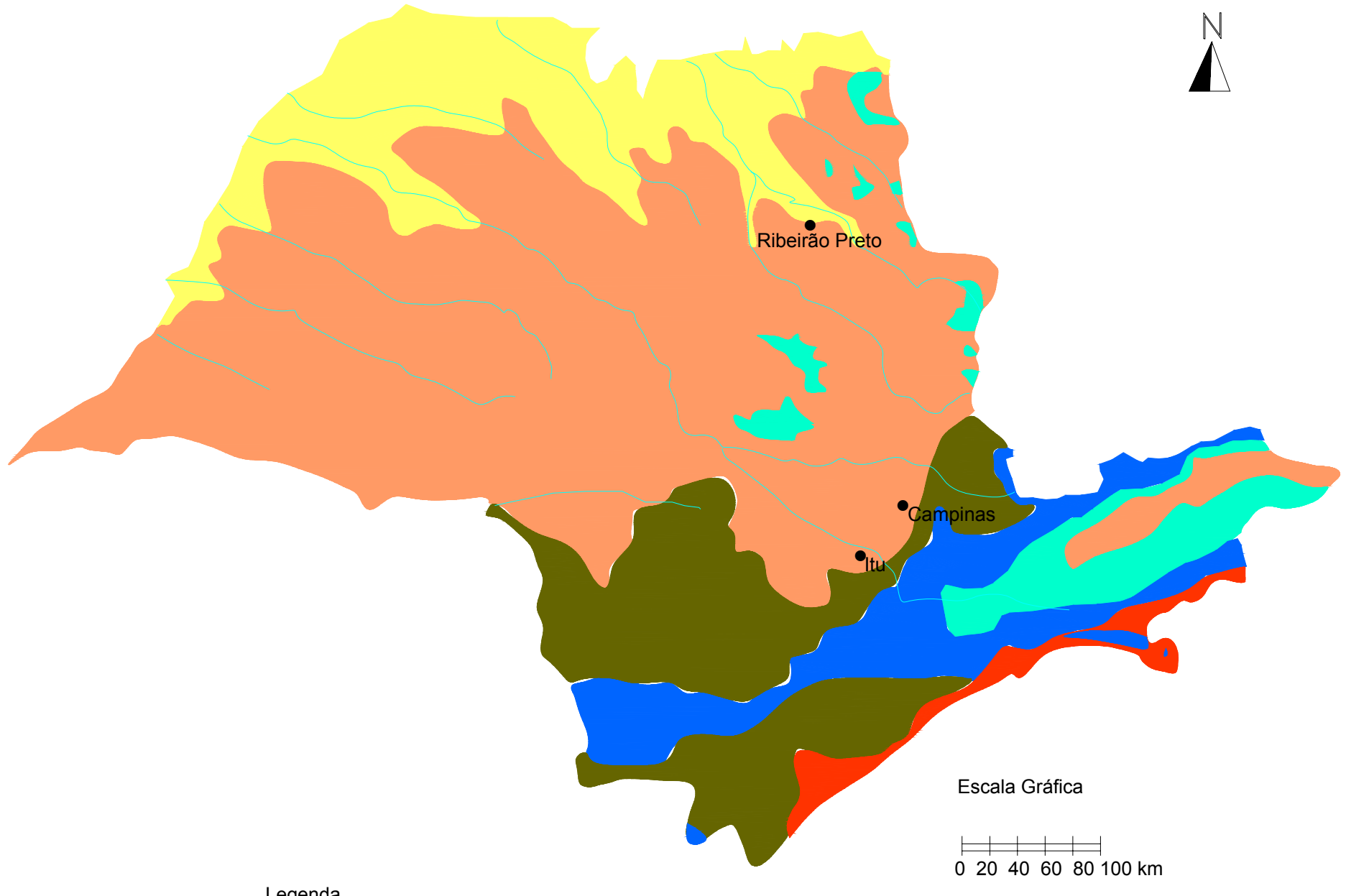

Legenda

Af - Tropical Úmido

Aw - Tropical

Cwa - Quente

Cwb - Temperado

Cfa - Quente

Cfb - Temperado

- $\quad$ Áreas de Estudo

Fonte: Setzer (1944)

Anexo D - Divisão Climática do Estado de São Paulo 


\section{REFERÊNCIAS BIBLIOGRÁFICAS}

ACEVEDO, C.R.; NOHARA, J.J. Monografia no curso de administração: guia completo de conteúdo e forma. São Paulo: Atlas, 2004. 181p.

BARCELLOS, V.Q. Os novos papéis do parque público: o caso dos parques de Curitiba e do projeto orla de Brasília. www.unb.br/fau/pos_graduacao/cadernos_eletronicos/ parques/parques.html (08 maio 2005).

BITAR, O.Y. Avaliação da recuperação de áreas degradadas por mineração na Região Metropolitana de São Paulo. São Paulo, 1997. 185p. Tese (Doutorado) - Escola Politécnica, Universidade de São Paulo.

BRASIL MINERAL 2003. A Mineração e o Meio Ambiente. Abril/2003 p.12-15. (Edição Especial, 217).

BRASIL. Constituição da República Federativa do Brasil. São Paulo: Editora Ipê, 1988. 79p.

BRASIL. Decreto $\mathrm{n}^{\mathrm{o}} 24.643$ de 10 de julho de 1934 (Código de Águas). www.aneel.gov.br/cedoc/dec193424643.pdf (05 abr. 2005). Decreta o Código de Águas. 
BRASIL. Decreto $\mathrm{n}^{\mathrm{o}}$ 97.632, de 10 de abril de 1989. http://www.mct.gov.br/legis/decretos/97632_89.htm (05 abr. 2005). Dispõe sobre a regulamentação do artigo $2^{\circ}$, inciso VIII, da Lei ${ }^{\circ} 6.938$ de 31 de agosto de 1981 e dá outras providências.

BRASIL. Decreto-Lei no 227 de 27 de fevereiro de 1967. www.dnpm.gov.br/portal/ conteudo.asp IDSecao $=67 \&$ IDPagina $=84 \&$ IDLegislacao $=4$ (05 abr. 2005). Código de Mineração.

BRASIL. Lei $\mathrm{n}^{\mathrm{o}} 4.771$ de 15 de setembro de 1965 (Código Florestal). www.lei.adv.br/4771-65.htm (05 abr. 2005). Institui o Novo Código Florestal.

BRASIL. Lei no 6.938 de 31 de agosto de 1981. www.silex.com.br/leis/1_6938.html (05 abr. 2005). Dispõe sobre a Política Nacional do Meio Ambiente, seus fins e mecanismos de formulação e aplicação e dá outras providências.

BRASIL. Lei $\mathrm{n}^{\mathrm{o}} 8.876$ de 02 de maio de 1994. www.planalto.gov.br/ccivil_03/LEIS/L8876.htm (05 abr. 2005). Autoriza o Poder Executivo a instituir como Autarquia o Departamento Nacional de Produção Mineral (DNPM), e dá outras providências.

BRASIL. Lei $n^{\circ} 9.433$ de 08 de janeiro de 1997 (Política Nacional de Recursos Hídricos). www.lei.adv.br/9433-97.htm (05 abr. 2005). Institui a Política Nacional de Recursos Hídricos, cria o Sistema Nacional de Gerenciamento de Recursos Hídricos, regulamenta o inciso XIX do art. 21 da Constituição Federal, e altera o art. $1^{\circ}$ da Lei $n^{\circ} 8.001$, de 13 de março de 1990, que modificou a Lei $n^{\circ} 7.990$, de 28 de dezembro de 1989. 
BRASIL. Lei $\mathrm{n}^{\mathrm{o}} 9.605$ de 12 de fevereiro de 1998. www.mma.gov.br/port/gab/asin/lei.html (05 abr. 2005). Dispõe sobre as sanções penais e administrativas derivadas de condutas e atividades lesivas ao meio ambiente, e dá outras providencias.

BRASIL. Lei $\mathrm{n}^{\mathrm{o}}$ 9.985, de 18 de junho de 2000. www.geocities.yahoo.com.br/ ambientche/lei_9985.htm (05 abr. 2005). Regulamenta o art. 225, § $1^{\circ}$, incisos I, II, III, e VII da Constituição Federal, institui o Sistema Nacional de Unidades de Conservação da Natureza e dá outras providências.

BRASIL. Resolução CONAMA $\mathrm{n}^{\circ} \quad 01$ de 23 de janeiro de 1986. www.mma.gov.br/port/conama/res/res86/res0186.html (05 abr. 2005). Estabelece a apresentação do EIA/RIMA (Estudo de Impacto Ambiental / Relatório de Impacto do Meio Ambiental) e dá outras providências.

BRASIL. Resolução CONAMA $\mathrm{n}^{\mathrm{o}} 09$ de 06 de dezembro de 1990. www.mma.gov.br/port/conama/index.cfm (05 abr. 2005). Dispõe sobre normas específicas para o licenciamento ambiental de extração mineral, classes I, III a IX.

BRASIL. Resolução CONAMA $\mathrm{n}^{\mathrm{o}} 010$ de 06 de dezembro de 1990. www.mma.gov.br/port/conama/index.cfm (05 abr. 2005). Dispõe sobre normas específicas para o licenciamento ambiental de extração mineral, classe II.

BRASIL. Resolução CONAMA $\mathrm{n}^{\mathrm{o}} 237$ de 19 de dezembro de 1997. www.mma.gov.br/port/conama/res/res97/res23797.html (05 abr. 2005). Complementa a Resolução CONAMA 01/86. 
BRASIL. Resolução CONAMA no 302 de 20 de março de 2002. www.mma.gov.br /port/conama/index.cfm (05 abr. 2005). Dispõe sobre os parâmetros, definições e limites de Áreas de Preservação Permanente de reservatórios artificiais e o regime de uso do entorno.

BRASIL. Resolução CONAMA n 303 de 20 de março de 2002. www.mma.gov.br /port/conama/index.cfm (05 abr. 2005). Dispõe sobre parâmetros, definições e limites de Áreas de Preservação Permanente.

CARVALHO, L.M. de. Áreas verdes da cidade de Lavras/MG: caracterização, usos e necessidades. Lavras, 2001. 115p. Dissertação (Mestrado) - Universidade Federal de Lavras.

CASTRO, J. P. C. de Conceituação e caracterização de áreas degradadas. In: DIAS, J. E.; MELLO, J. W. M. de (Org.). Recuperação de áreas degradadas. Viçosa: UFV, 1998. p. 9-13.

CAVAlHEIRO, F.; DEL PICCHIA, P.C.D. Áreas Verdes: conceitos, objetivos e diretrizes para o planejamento. In: CONGRESSO BRASILEIRO SOBRE ARBORIZAÇÃO URBANA, 1.; ENCONTRO NACIONAL SOBRE ARBORIZAÇÃO URBANA, 4., Vitória, 1992. Anais. Vitória: PREFEITURA, 1992. v. 1, p.29-37.

CAVALHEIRO, F.; NUCCI, J.C. Espaços livres e qualidade de vida urbana. Paisagem Ambiente Ensaios, n.11, p.277-88, 1998.

CHADDAD, J. Evolução urbana na arquitetura e no paisagismo. In: DEMÉTRIO, U. A; CHADDAD, J.; LIMA, A.M.L.P.; CHADDAD JÚNIOR, J. Composição paisagística em parques e jardins. Piracicaba: FEALQ, 2000. cap.1, p.7-17. 
CIELO FILHO, R.; SANTIN, D.A. Estudo florístico e fitossociológico de um fragmento florestal urbano - Bosque dos Alemães. Revista Brasileira de Botânica, v.25, n.3, p.291-301, set. 2002.

CITY BRAZIL www.citybrazil.com.br/sp/ribeiraopreto/ (23 abr. 2005a).

CITY BRAZIL. www.citybrazil.com.br/sp/itu/ (23 abr. 2005b).

CITY BRAZIL www.citybrazil.com.br/sp/campinas/ (23 abr. 2005c).

COMPANHIA DE TECNOLOGIA E SANEAMENTO AMBIENTAL. Relatório de qualidade do ar no Estado de São Paulo 2002. São Paulo: CETESB, 2003. 130p.

DEMATTE, M.E.S.P. Princípios de paisagismo. Jaboticabal: Funep, 1997. 104p.

DIAS, E.G.C.S. Avaliação de impacto ambiental de projetos de mineração no Estado de São Paulo: a etapa de acompanhamento. São Paulo, 2001. 283p. Tese (Doutorado) Escola Politécnica, Universidade de São Paulo.

DIAS, L.E.; GRIFFITH, J. J. Conceituação e caracterização de áreas degradadas. In: DIAS, J. E.; MELLO, J. W. M. de (Org.). Recuperação de áreas degradadas. Viçosa: UFV, 1998. p. 1-7.

DEPARTAMENTO NACIONAL DE PRODUÇÃO MINERAL (DNPM). Sumário Mineral 2004. Brasília: DNPM, v.24, 2004. 33p.

ESCADA, M.I.S. Utilização de técnicas de sensoriamento remoto para o planejamento de espaços livres urbanos de uso coletivo. São José dos Campos, 1992. 133p. Dissertação (Mestrado) - Instituto Nacional de Pesquisas Espaciais. 
FARIAS, C.E.G. Mineração e meio ambiente no Brasil. São Paulo, 2002. 39p. (Relatório preparado para o CGEE)

FRANCO, M de A.R. Planejamento ambiental para a cidade sustentável. 2.ed. São Paulo: Annablume/FAPESP, 2001. 296p.

FREIRE, H. B. Sistemas de lazer e violência urbana: estudo da relação no município de Piracicaba-SP. Piracicaba, 2005. 75p. Dissertação (Mestrado) - Escola Superior de Agricultura "Luiz de Queiroz", Universidade de São Paulo.

GUZZO, P. Áreas verdes urbanas. www.educar.sc.usp.br/biologia/prociencias/ areasverdes.html (05 ago. 2003).

INSTITUTO BRASILEIRO DE GEOGRAFIA E ESTATÍSTICA (IBGE). Mapa da vegetação do Brasil. Rio de Janeiro: IBGE, 1993. Folha 5C-20-Z-A, Escala 1:5.000.000.

INSTITUTO BRASILEIRO DE GEOGRAFIA E ESTATÍSTICA (IBGE). www.ibge.gov.br/ (11 jun. 2005).

INSTITUTO DE PESQUISAS TECNOLÓGICAS (IPT). Mapa geológico do Estado de São Paulo. São Paulo: IPT, 1981a. v.I e II. Escala 1: 500.000. 94p.

INSTITUTO DE PESQUISAS TECNOLÓGICAS (IPT). Mapa geomorfológico do Estado de São Paulo. São Paulo: IPT, 1981b. v.I e II. Escala 1: 1.000.000. 94p.

ITU: paraíso documentário de uma das mais antigas glaciações do mundo. Diário da Noite, Itu, jun. 1962. p.1.

KLIASS, R.G. Parques urbanos de São Paulo. São Paulo: Editora Pini, 1993. 164p. 
KOTCHETKOFF-HENRIQUES, O. Caracterização da vegetação natural em Ribeirão Preto, SP - Bases para conservação. Ribeirão Preto, 2003. 221p. Tese (Doutorado) Faculdade de Filosofia, Ciências e Letras de Ribeirão Preto, Universidade de São Paulo.

LEINZ, V. Estudos sobre a glaciação permo-carbonífera do Sul do Brasil. Brasília: DNPM, 1937. 47p. (Boletim, 21).

LIMA, A.M.L.P.; CAVALHEIRO, F.; NUCCI, J.C.; SOUZA, M.A. de L.B.; FIALHO, N. de O.; DEL PICCHIA, P.C.D. Problemas de utilização na conceituação de termos como espaços livres, áreas verdes e correlatos. In: CONGRESSO BRASILEIRO DE ARBORIZAÇÃO URBANA, 2.; ENCONTRO NACIONAL SOBRE ARBORIZAÇÃO URBANA, 5., São Luiz, 1994. Anais. São Luis: Sociedade Brasileira de Arborização Urbana, 1994. p.539-553.

LIRA FILHO, J. A. de; PAIVA, H. N. de; GONÇALVES, W. Paisagismo: princípios básicos. Viçosa: Aprenda Fácil, 2001. 166p.

MACEDO, S. S.; SARATA, F. G. Parques urbanos no Brasil. 2.ed. São Paulo: Edusp, 2003. 206p.

MAPAS TERRA. www.mapas.terra.com.br (20 jun 2005)

MASCHIO, L.M.A.; BALENSIEFER, M.; RACHIVAL, M. F. G.; CURCIE, G.; MONTOYA, G. Evolução, estágio e caracterização da pesquisa em recuperação de áreas degradadas no Brasil. In: SIMPÓSIO NACIONAL SOBRE RECUPERAÇÃO DE ÁREAS DEGRADADAS, 1., Curitiba, 1992. Anais. Curitiba: FUPEF, 1992. p.17-33. 
MELlO, I. S. de C.; CABRAL JÚNIOR, M.; MOTTA, J. F. M.; CUCHIERATO, G. Pólos produtores de bens minerais de uso na construção civil do Estado de São Paulo. São Paulo: Instituto de Pesquisas Tecnológicas, 1998. (Publicação IPT, 2524).

MENDES, J. C. A geologia dos arredores de Itu. Boletim da Associação dos Geógrafos Brasileiros, v.4, p.31-40, 1944.

MINAS GERAIS. Constituição do Estado de Minas Gerais de 21 de setembro de 1989. www.educacao.mg.gov.br/files/down/legislacao_constituicao_estadual.pdf (05 abr. 2005).

MINISTÉRIO DAS MINAS E ENERGIA (MME). Projeto Radambrasil. Rio de Janeiro: MME, 1983. 775p. (Folhas SF 23/24).

MOREIRA, I.V.D. Vocabulário básico de meio ambiente. 4.ed. Rio de Janeiro: FEEMA/PETROBRAS, 1992. 246p.

NAVARRO, J. Paisagens de Itu - LXXVII. “A Federação" Caderno Extra, 03 jul. 1993. p.1-2.

NUCCI, J.C. Qualidade ambiental e adensamento: um estudo de planejamento da paisagem do Distrito de Santa Cecília (Município de São Paulo). São Paulo, 1996. 229p. Tese (Doutorado) - Faculdade de Filosofia, Letras e Ciências Humanas, Universidade de São Paulo.

O MELHOR DE ITU. www.itu.com.br (07 maio 2005).

OLIVEIRA, C. H. Planejamento ambiental da cidade de São Carlos/SP com ênfase nas áreas públicas e áreas verdes: diagnóstico e propostas. São Carlos, 1996. 181p. Dissertação (Mestrado) - Universidade Federal de São Carlos. 
ORTOLANO, A.A.; CAMARGO, M.B.P.; PEDRO JÚNIOR, M.J. Normas climatológicas dos postos meteorológicos do Instituto Agronômico: 1. Campinas: Instituto Agronômico de Campinas, 1995. p.10.

PARQUE do Varvito. Itu: Prefeitura da Estância Turística de Itu, s.d. 1 folder.

PREFEITURA MUNICIPAL DE CAMPINAS. www.campinas.sp.gov.br/ (23 abr. 2005).

PREFEITURA MUNICIPAL DE CAMPINAS. Lei Municipal $\mathrm{n}^{\mathbf{0}} 7.352$ de 01 de dezembro de 1992. Diário Oficial do Município de Campinas.

PREFEITURA MUNICIPAL DE RIBEIRÃO PRETO. www.ribeiraopreto.sp.gov.br /index.html (23 abr. 2005).

PREFEITURA MUNICIPAL DE RIBEIRÃO PRETO. Código do Meio Ambiente. Ribeirão Preto: Prefeitura Municipal de Ribeirão Preto, 2004. 42p.

PREFEITURA MUNICIPAL DE RIBEIRÃO PRETO. Decreto no 163 de 27 de junho de 2.000. www.ribeiraopreto.sp.gov.br (05 abr. 2005). Declara de utilidade pública o imóvel descrito na escritura de desapropriação amigável ou judicial de 21 de julho de 2.000 .

PREFEITURA MUNICIPAL DE RIBEIRÃO PRETO. Decreto $n^{\circ} 185$ de 23 de junho de 2.003. www.ribeiraopreto.sp.gov.br (05 abr. 2005). Regulamenta a Lei Complementar $n^{\circ}$ 1.009/00 de 15 de maio de 2000 e decreta as finalidades do Parque Curupira. 
PREFEITURA MUNICIPAL DE RIBEIRÃO PRETO. Decreto $\mathrm{n}^{\circ} 630$ de 14 de novembro de 2.000. www.ribeiraopreto.sp.gov.br (05 abr. 2005).

PREFEITURA MUNICIPAL DE RIBEIRÃO PRETO. Lei complementar no 1.009 de 15 de maio de 2.000. www.ribeiraopreto.sp.gov.br (05 abr. 2005). Define o imóvel e declara a área de interesse especial.

PREFEITURA MUNICIPAL DE RIBEIRÃO PRETO. Lei Complementar $n^{\circ} 1.204$ de 10 de abril de 2.001. www.ribeiraopreto.sp.gov.br (05 abr. 2005).

PREFEITURA MUNICIPAL DE RIBEIRÃO PRETO. Lei Complementar $\mathrm{n}^{\circ} 1.215$ de 04 de maio de 2.001. www.ribeiraopreto.sp.gov.br (05 abr. 2005). Regulamenta os convênios da Prefeitura Municipal de Ribeirão Preto com empresas, associações culturais, esportivas ou de serviços, Universidades, instituições de ensino, associações de profissionais ou de classe, sindicatos, associações de moradores e similares, para a estruturação e manutenção dos parques e das Unidades de Conservação municipais.

PREFEITURA MUNICIPAL DE RIBEIRÃO PRETO. Lei Complementar $n^{\circ} 1.272$ de 28 de novembro de 2.001. www.ribeiraopreto.sp.gov.br (05 abr. 2005). Dispõe sobre o Parque Curupira e estabelece disposições correlatas, cria restrições de uso de seu entrono e dá outras providências.

PREFEITURA MUNICIPAL DE RIBEIRÃO PRETO. Lei n ${ }^{\circ} 10.186$ de 15 de setembro de 2004. www.ribeiraopreto.sp.gov.br (05 abr. 2005). Altera a denominação de CURUPIRA PARQUE DA CIDADE para "PARQUE PREFEITO LUIZ ROBERTO JÁBALI". 
RICCIARDI, C. T. R; SÁNCHEZ, L. E. Reabilitação e novo uso de áreas mineradas: um apanhado de alguns casos em São Paulo. Revista Areia e Brita, n.27. p.26-34, 2004.

RODRIGUES, R.R.; GANDOLFI, S. Conceitos, tendências e ações para a recuperação de florestas ciliares. In: RODRIGUES, R.R.; LEITÃO FILHO, H. de F. Matas Ciliares: Conservação e recuperação. 2.ed. São Paulo: EDUSP, 2001. p.235-247.

ROSS, J.L.S.; MOROZ, I. C. Mapa geomorfológico do Estado de São Paulo. São Paulo: FFLCH/USP/IPT/FAPESP, 1997. Mapas e Relatório, Escala 1:500.000. 65p.

SÁNCHEZ, L.E. Projetos de recuperação: usos futuros e a relação com a comunidade. In: ENCONTRO DE MINERAÇÃO NO MUNICÍPIO DE SÃO PAULO, 1., São Paulo, 1994. Anais. São Paulo: SAR/PMSP/Epusp, 1995. p.53-83.

SANCHOTENE, M do C.C. Conceitos e Composição do índice de áreas verdes. Boletim Informativo da Sociedade Brasileira de Arborização Urbana, n.1, p.4-9, 2004.

SANTIN, D.A. A vegetação remanescente do município de Campinas (SP): mapeamento, caracterização fisionômica e florística, visando a conservação. Campinas, 1999. Tese (Doutorado) - Universidade Estadual de Campinas.

SANTOS, K.; KINOSHITA, L.S. Floristic composition of the woody flora of the Ribeirão Cachoeira forest, Campinas, São Paulo State. Acta Botanica Brasileira, v.17, n.3, p.325-341, jul./set. 2003.

SÃO PAULO. Constituição do Estado de São Paulo de 05 de outubro de 1989. www.legislacao.sp.gov.br/dg280202.nsf/0/46e2576658b1c52903256d63004f305a?O penDocument (05 abr. 2005). 
SÃO PAULO. Resolução SMA $\mathrm{n}^{\mathrm{o}} \quad 18$ de 2 de agosto de 1989. www.ambiente.sp.gov.br/leis_internet/estadual/txt_resolucao.htm (05 abr. 2005). Dispõe sobre Plano de Recuperação de Áreas Degradadas.

SÃO PAULO. Resolução SMA $\mathrm{n}^{\mathrm{o}} \quad 04$ de 22 de janeiro de 1999. www.ambiente.sp.gov.br/leis_internet/uso_solo/mineracao/res_sma499.htm (05 abr. 2005). Disciplina o procedimento para o licenciamento ambiental integrado das atividades minerárias.

SÃO PAULO. Resolução SMA $\mathrm{n}^{\mathrm{o}} \quad 26$ de 30 de agosto de 1993. www.ambiente.sp.gov.br/leis_internet/uso_solo/mineracao/res_sma2693.htm $\quad(05$ abr. 2005). Disciplina o licenciamento ambiental dos empreendimentos minerários no Estado de São Paulo.

SÃO PAULO. Resolução SMA $\mathrm{n}^{\mathrm{o}} \quad 42$ de 29 de dezembro de 1994. www.ambiente.sp.gov.br/leis_internet/geral/licenc/sma4294.htm (05 abr. 2005). Procedimentos para análise de EIA/RIMA

SILVA, J.A. Direito urbanístico brasileiro. São Paulo: Editora Revista dos Tribunais, 1981. 617p.

SECRETARIA DE ESTADO DO MEIO AMBIENTE (SMA). Atlas das Unidades de Conservação Ambiental do Estado de São Paulo. São Paulo: SMA. 2000.

SISTEMA INTEGRADO DE GERENCIAMENTO DE RECURSOS HÍDRICOS DE SÃO PAULO. www.sigrh.sp.gov.br (20 jun. 2005).

SETZER, J. O Clima do Estado de São Paulo. Boletim Geográfico IBGE, n.19, p. 11$20,1944$. 
SPADOTTO, C.A. Classificação de impacto ambiental. www.cnpma.embrapa.br/ herbicidas/ (10 jun. 2002).

TANNO, L.C.; SINTONI, A. Mineração \& município: bases para planejamento e gestão dos recursos minerais. São Paulo: Instituto de Pesquisas Tecnológicas, 2003. $177 \mathrm{p}$.

TIMO, T.P.C. Caracterização, análise e elaboração de um banco de dados georreferenciado para a arborização viária urbana da cidade de Luiz Antônio (SP). São Carlos, 2001. 33p. Monografia (Bacharelado) - Universidade Federal de São Carlos.

TOY, T.; GRIFFITH, J.J. Recuperação ambiental: evolução das práticas nas lavras de Minas Gerais. Parte 1. Brasil Mineral, n.209, p.34-40, 2002a.

TOY, T.; GRIFFITH,J.J. Recuperação ambiental: evolução das práticas nas lavras de Minas Gerais. Final. Brasil Mineral, n.210, p.26-33, $2002 b$.

VALVERDE, F. M. Agregados para construção civil. In: DEPARTAMENTO NACIONAL DE PRODUÇÃO MINERAL (DNPM). Balanço mineral brasileiro 2001. Brasília: DNPM, 2001. p.1-15. http://www.dnpm.gov.br/portal/assets/ galeriaDocumento/BalancoMineral2001/agregados.pdf (05 abr. 2005).

VALVERDE, F. M. Agregados para construção civil. In: DEPARTAMENTO NACIONAL DE PRODUÇÃO MINERAL (DNPM). Sumário Mineral 2004. Brasília: DNPM, 2004. p. 25-26. www.dnpm.gov.br (05 abr. 2005).

WILlianS, D.D.; BUGIN, A.; REIS, J.L.B. (Coord.) Manual de recuperação de áreas degradadas pela mineração: técnicas de revegetação. Brasília: IBAMA, 1990. 96p. 
YIN, R. K. Case study research: design and methods. London: Sage Publications, 1984.171p. 